UNIVERSIDADE DE SÃO PAULO

INSTITUTO DE ESTUDOS BRASILEIROS

PROGRAMA DE PÓS-GRADUAÇÃO CULTURAS E IDENTIDADES BRASILEIRAS

THIAGO RIGHI CAMPOS DE CASTRO

A Paulistânia, o mineiro e o italiano: cultura caipira, processo histórico e acesso à terra no fonograma de uma moda de viola 


\section{A Paulistânia, o mineiro e o italiano: cultura caipira, processo histórico e acesso à terra no fonograma de uma moda de viola}

\section{Versão Corrigida}

(a versão original encontra-se disponível no Instituto de Estudos Brasileiros - IEB/USP)

Dissertação apresentada ao Programa de

Pós-Graduação Culturas e Identidades

Brasileiras do Instituto de Estudos

Brasileiros da

Universidade de São Paulo, para a

obtenção do título de Mestre em Filosofia.

Área de concentração: Estudos Brasileiros

Orientador: prof. Dr. Walter Garcia da

Silveira Junior 
DADOS DE CATALOGAÇÃO NA PUBLICAÇÃO (CIP)

Serviço de Biblioteca e Documentação do

Instituto de Estudos Brasileiros da Universidade de São Paulo

C355

Castro, Thiago Righi Campos de

A Paulistânia, o mineiro e o italiano : cultura caipira, processo histórico e acesso à terra no fonograma de uma moda de viola / Thiago Righi Campos de Castro ; Walter Garcia da Silveira Júnior, orientador -- São Paulo, 2020.

Dissertação (Mestrado) - Universidade de São Paulo. Instituto de Estudos Brasileiros. Programa de Pós-Graduação em Culturas e Identidades Brasileiras. Área de concentração: Estudos Brasileiros. Linha de pesquisa: Brasil: a realidade da criação, a criação da realidade.

Título em inglês: Paulistânia, the mineiro and the Italian : caipira culture, historical process and land issues on a phonogram of a moda de viola song - São Paulo, SP.

Descritores: 1. Vieira, Teddy, 1922-1965 2. Tião Carreiro e Pardinho 3. Cultura popular - Brasil 4. Música caipira 5. Fonograma 6. Paulistânia I. Universidade de São Paulo. Instituto de Estudos Brasileiros. Programa de Pós-Graduação II. Silveira Júnior, Walter Garcia da, orient. III. Título. 


\section{Resumo}

O fonograma da moda de viola "O mineiro e o italiano", composição de Teddy Vieira e Nelson Gomes gravada em 1964 pela dupla de música caipira Tião Carreiro e Pardinho, constitui-se como núcleo deste trabalho. Quando considerado em sua totalidade, este registro demonstra força evocativa e potencial sugestivo capazes de produzir uma interessante síntese. Ao mobilizar todo um conjunto de personagens, signos, símbolos, relações, lugares-comuns, os elementos constitutivos e formais do fonograma apontam e/ou presumem elementos característicos e aspectos importantes da história e experiência do caipira e de sua cultura. Por meio da descrição, comentário, análise e interpretação do conteúdo que dá sentido e coesão à narrativa (literária e musical), esta dissertação intenta investigar em que medida essa

canção popular pode ser compreendida enquanto síntese do processo histórico e da experiência histórica e cultural da Paulistânia.

\section{Palavras-chave}

1. Vieira, Teddy, 1922-1965; 2. Tião Carreiro e Pardinho; 3. Cultura Popular-Brasil; 4. Música caipira; 5. Fonograma; 6. Paulistânia. 


\section{Abstract \\ Paulistânia, the mineiro and the Italian: caipira culture, historical process and land issues on a phonogram of a moda de viola song.}

The phonogram of "O mineiro e italiano", a moda de viola song composed by Teddy Vieira and Nelson Gomes recorded in 1964 by the caipira's music duo Tião Carreiro and Pardinho is the core of this work. Taken in its entirety, this phonogram demonstrates evocative force and suggestive potential that can produce an interesting synthesis. By mobilizing a whole set of characters, signs, symbols, relationships, commonplaces, the constitutive and formal elements of this phonogram points to and / or assume characteristic elements and important aspects of the history and experience of the caipira (redneck) and its culture. Through the description, commentary, analysis and interpretation of the content that gives meaning and cohesion to the narrative (literary and musical) of this work, this dissertation intends to investigate to what extent this popular song can be understood as a synthesis of the historical process and the historical-cultural experience of Paulistânia's region and peoples.

\section{Key-words}

1. Vieira, Teddy, 1922-1965; 2. Tião Carreiro e Pardinho; 3. Popular Culture - Brazil; 4. Caipira's music; 5. Phonogram; 6. Paulistânia. 
Para meus pais e avós,

fontes primárias de minha caipirice. 
"A canção se realiza fundada na vida concreta da sociedade." Walter Garcia

“[...] o poder sugestivo da música é formidável." Mário de Andrade 


\section{Agradecimentos}

Ao professor Dr. Walter Garcia, pelo comprometimento, paciência, dedicação e rigor durante toda minha caminhada neste Mestrado.

Aos professores Dra. Flávia Toni, Dr. Jaime Oliva, Dr. José Roberto Zan, Dr. Sérgio de Carvalho e Dra. Tania Costa Garcia, e à Dra. Juliana González.

À minha companheira Camila Soares, meus pais Tadeu e Maria Rosa, meu irmão Thales e cunhada Jéssica.

Aos amigos e colegas que, ao longo da pesquisa, contribuíram com perguntas, ouvidos, debates, interesse pelo assunto desta Dissertação. Agradeço, em especial, Andreia dos Guimarães e Rodrigo Digão Braz, que tiveram participação ativa e decisiva em assuntos relacionados ao conteúdo musical da obra que analisei.

Ao IEB, à USP e seus funcionários, pela estrutura e suporte. 


\section{Sumário}

Ø. Introdução 9

Capítulo I

1. Paulistânia: berço da cultura Caipira 17

1.1 Música dos caipiras, música caipira, música sertaneja: do folclore ao disco 25

1.2 Teddy Vieira 43

1.3 Teddy Vieira, Tião Carreiro (José Dias Nunes), Pardinho (Antônio Henrique de Lima): encontro para o sucesso. 49

1.4 Tião Carreiro e Pardinho 53

1.5 "O mineiro e o italiano" 61

\section{Capítulo II}

2. A síntese e os sentidos de "O mineiro e o italiano" 62

2.1 São todos caipiras! 73

2.2 Um mineiro paulistânico e caipira 76

2.3 O italiano 81

2.4 O juiz quatrocentão e o advogado aconselhador 87

2.5 Uma demanda de terra sob os olhos da justiça de um mundo cordial 89

2.6 A questão do humor 92

2.7 Aspectos musicais de "O mineiro e o italiano": quando a música informa tanto quanto a letra 94

\section{Capítulo III}

3. A questão da terra e do relógio 117

๑ Coda 131

Anexos 132

Referências Bibliográficas 136 


\section{Ø. Introdução}

A partir das vicissitudes da colonização da América portuguesa, do movimento inicial do bandeirante, de sua posterior fixação e do desenrolar do processo histórico da Paulistânia, originou-se, "em certas porções" desse grande território, uma cultura singular, à qual Antonio Candido denominou "cultura caipira" (CANDIDO, 2001). Para Ivan Vilela, seu "processo de formação confundiu-se com a própria colonização do centro-sul brasileiro", em uma experiência na qual "foi se moldando uma cultura peculiar em seus vários aspectos" (VILELA 2015, p. 153), que não só se desenvolveu como também se conservou ao longo do tempo (CANDIDO, 2001, p. 45 e 102; VILELA 2015, p. 153-155). Para tanto, historicamente, a tradição oral se configurou como uma das principais maneiras de transmissão de valores e conhecimentos (VILELA 2015, p. 159; ANDRADE, 2013, p. 141145), sendo que, dentre os diferentes meios de transmissão oral possíveis, a música representou uma importante e eficaz via.

Assim, imiscuído ao decurso da colonização dessa ampla região geográfica, “o processo de formação da cultura caipira" legou uma produção musical que "se apresenta como uma voz a narrar as próprias agruras, alegrias e o [...] cotidiano [do caipira]. Na música, [ele] encontra uma maneira particular de perpetuar seus valores, história, cultura" (VILELA, 2015, p. 153 e 159). Conforme escreveu Ivan Vilela,

tendo o romance como a base poemática de suas canções, os caipiras sempre transmitiram valores de seu meio através de sua música. Através dela rebateram críticas, narraram momentos de penúria, manifestaram sua fé, seu amor, levantaram-se contra a arrogância de outrem, celebraram seus animais [...]. (VILELA, 2015, p. 134)

No mesmo sentido de Vilela, José Hamilton Ribeiro entende essa música "como registro de um tempo", e afirma que "a música caipira é uma crônica da vida no Brasil em determinada fase e numa determinada época” (RIBEIRO, 2015, p. 27 e 25, respectivamente).

A partir disso e tendo em conta que "a música exprime e potencia uma rede de sentimentos e valores que dão forma e sentido à cultura popular", e que, no meio rural brasileiro, "a música sempre foi um componente central da vivência simbólica" das comunidades (BOSI apud VILELA 2015, p. 16), é possível pensarmos que a música se portou como um elemento mediador nas relações dessas comunidades rurais." (VILELA, 2015, p. 59). 
Para além desse fato, dado que "os povoadores isolados não têm história, senão na medida em que penetram, por uma razão ou outra, na órbita do povoamento condensado" (CANDIDO, 2017, p. 72), a canção e a fonografia caipiras se apresentam como bens simbólicos que contribuem para que a cultura, a experiência e a história do caipira, para além de serem narradas, não sejam esquecidas, perdidas, silenciadas. Visto que "toda uma tradição social fundada sobre bases agrárias entrou em declínio a partir da crise de 1929 e do movimento de 1930" (GARCIA, 2013, p. 21) e que "os valores do mundo caipira foram desaparecendo gradativamente, perdendo sua função em um mundo que se modernizava (VILELA, 2015, p. 24), o Brasil pós 1950 surgia como o anátema da cultura caipira e sua gente (CANDIDO, 2001, p. 269-283). Tendo em conta que "as narrativas orais têm fundamental importância nos meios não letrados, pois é por elas que a memória da comunidade é trazida ao presente de maneira a nortear seus pressentimentos em relação ao futuro" (VILELA, 2015, p. 91), conclui-se que a música do caipira atuou como "mantenedora dos valores referenciais desse povo" (VILELA, 2015, p. 145) no momento exato em que sua cultura perdia a razão e o sentido de ser frente a um Brasil que se transformava rapidamente. Foi além, ao conservar, também, a história dessa gente: “em um mundo onde quase só aprendemos a história única dos vencedores, pela produção musical dos caipiras tivemos acesso a uma história dos vencidos, dos que se sujeitaram mas não tombaram, não perderam o senso de si próprios" (VILELA, 2015, p. 145). Afinal, "não fosse pelo disco [e pelas ondas do rádio], o caipira jamais conseguiria transmitir sua história de enraizamento e fazê-la conhecida por todos" (VILELA, 2015, p. 66), dado que "o esquecimento, ou a exclusão, dos homens livres das camadas pobres nos estudos históricos sobre o Brasil foi uma constante não apenas no discurso mas também na historiografia oficiais” (SETUBAL, 2005, p. 35).

Isso posto, e em acordo também com Elizabeth Travassos, esta dissertação parte do pressuposto de que "a própria música pode ser um modo de fazer a história" (TRAVASSOS, 2007, p. 6). Dessa forma, é atenta e responde à crítica de Lucas Antonio de Araújo de que "a maior parte dos trabalhos que se voltam para a música sertaneja não se atém à visão de história e do passado, em um gênero musical que se empenha justamente em construir uma narrativa do passado e de formação da sociedade brasileira" (ARAÚJO, 2014, p. 180).

Em adição, cabe chamar a atenção, ainda, para uma outra dimensão que a inserção e a função social dessa música dos caipiras pode assumir. Dotada de um "efeito significativo particularmente fecundo", essa música traz em si o potencial de "despertar uma energia imaginativa pelo devaneio grupal"; energia essa que "colabora para a tomada de consciência 
da vicissitude histórica do caboclo" (SANT'ANNA, 2009, p. 321). Conforme escreveu Romildo Sant'Anna,

esse fenômeno, deixando de lado sua função recreativa e poética, ressalta a grande importância que a Moda Caipira exerce como função empreendedora duma modificação do indivíduo e de sua consciência política. Sobressai dessa consciência do poder comunicativo por parte do poeta a ação emancipadora que a Moda exerce em seu meio. (SANT'ANNA, 2009, p. 321)

Através desse potencial transformador e de sua faculdade de sintetizar importantes aspectos do processo histórico e da experiência, em outras palavras, dessa sua surpreendente e notável capacidade de "traduzir os conteúdos humanos relevantes em pequenas peças formadas de melodia e letra" (TATIT, 2004, p. 11), a música dos caipiras “estabelece alusões ao mundo concreto e pertencimento simbólico de seu público" (SANT’ANNA, 2009, p. 320). Dessa forma, por meio dos comportamentos, histórias, experiências, valores, instituições, dramas e relações, cantados, e de suas especificidades estético-formais e de interpretação, essa música mobiliza signos e símbolos capazes de produzir História, sentido e síntese.

\footnotetext{
Mobilizados esses signos, eles interagem, se correlacionam, primeiramente, no espaço textual; após, nos intertextos da comunicação coletiva, e no espaço vivencial e significativo dos ouvintes, erigindo uma cadeia de significações latejantes. Assim, ao mesmo tempo, o conteúdo poemático se adensa de uma realidade virtual na medida em que é posto em funcionamento interativo com o plano da realidade empírica no presente ou herdada do passado. (SANT'ANNA, 2009, p. 320-321)
}

Por essa razão é que, "no caso peculiar da [moda de viola], como em geral da literatura popular de antiga procedência, é importante considerar não só o pólo da emissão como o circuito que se estabelece com o pólo da recepção” (SANT'ANNA, 2009, p. 318).

A existência desse circuito é que viabiliza tanto a formação daquela cadeia de significações e realidades virtuais quanto a chance de transformação e emancipação que o receptor de uma obra literária ou musical tem à disposição ao fruí-la.

Por outro lado, a percepção, descrição, análise e interpretação dos sentidos e sínteses produzidos por obras que compõem determinado circuito é o que propicia e potencializa uma 
melhor apreensão das alusões, sugestões e inferências ao mundo concreto, à história e experiência que são veiculados através das obras que dele fazem parte. Isso porque algumas obras apresentam "um campo de sugestividade que não prescinde, e até depende, de aportes extratextuais"' (SANT'ANNA, 2009, p. 318).

Um dos meios possíveis de se alcançar essa apreensão, e a assimilação dos efeitos significativos que toda aquela energia imaginativa é capaz de oferecer, se apresenta pela via da análise crítico-interpretativa de uma determinada obra do repertório de um circuito qualquer. Através do escrutínio dos sentidos e sínteses, das sugestões, evocações e inferências que a estrutura interna de uma canção, ao ser confrontada com o andamento do processo histórico ao qual pertence, apresenta, é possível descortinar, apontar ou insinuar modos de ser, ver e existir.

Assim sendo, este estudo está estruturado a partir da percepção de que, quando considerado em sua totalidade, o fonograma da moda de viola "O mineiro e o italiano" demonstra força evocativa e potencial sugestivo capazes de produzir uma interessante síntese. $\mathrm{Na}$ narrativa de sua letra e nos componentes estético-formais desta composição de Teddy Vieira e Nelson Gomes, gravada em 1964 pela dupla de música caipira Tião Carreiro e Pardinho, é possível perceber-se ingredientes que conformam e singularizam os modos de ser e os tipos de vida da Paulistânia e de seus habitantes. Ao mobilizar todo um conjunto de personagens, signos, símbolos, relações, instituições, lugares-comuns, os elementos constitutivos e formais desta canção apontam e/ou presumem elementos característicos, especificidades e aspectos importantes da história e da experiência do caipira e de sua cultura.

Para além disso, "a espessa relação de identidade entre o universo de signos em suas conotações culturais de que a moda se compõe e a situação social em que ela se insere" (SANT'ANNA, 2009, p. 330) fazem com que esta narrativa desvele, ainda, certas relações, a inserção e o lugar destas dentro do macrocosmo da cultura, experiência e história brasileiras. Algumas interrelações entre a cultura caipira (e seus integrantes) e o sistema social mais amplo no qual ela se insere são explicitadas, revelando todo um diálogo - por vezes conflituoso - entre mundos ao mesmo tempo excludentes e complementares.

Do que falam algumas canções? Essa é uma questão de valor estético que desemboca em outras variadas perguntas que tencionam um interessante jogo sobre os modos de falar de si, formas de se enxergar o mundo e maneiras de opinar sobre um determinado tempo histórico. (SOUSA, 2008, p. 152) 
Perceber "o que está sendo dito" e "como este conteúdo é transmitido" pelo fonograma de "O mineiro e o italiano" foi o que motivou este Mestrado. Investigar quais as possíveis perguntas e respostas que daí emergem, no esforço "de entender como, na atividade musical, um grupo social determinado, particular, elabora o nexo com o passado" (TRAVASSOS, 2007, p. 6), foi o que alimentou a trajetória desta pesquisa. Apontar, descrever, analisar e interpretar o interessante "jogo sobre os modos de falar de si, formas de se enxergar o mundo e maneiras de opinar sobre um determinado tempo histórico" (SOUSA, 2008, p. 152) que o registro desta moda de viola evoca, infere ou sugere, traduziu-se nos esforços da reflexão crítica e da escrita desta dissertação.

Norteando todo esse percurso, a sempre lembrança de que "a grandeza principal da canção popular" é sua "necessidade", pois ela, "é o ar gasto e usado que traz no seu sopro vivido o que não pôde esquecer lá dentro do homem: a experiência", como bem nos ensinou o autor de Macunaíma (ANDRADE, 2013, p. 145).

Walter Garcia afirma que "a forma artística da canção popular-comercial é complexa, pois se constrói na interação de várias técnicas" (GARCIA, 2013, p. 16). Pensar sobre, analisar e interpretar experiências, culturas e processos históricos por meio da música popular requer, portanto, uma abordagem multidisciplinar ${ }^{1}$.

Em acordo com este entendimento, este trabalho está fundado em uma análise crítico interpretativa que se realiza a partir do ponto de vista de diferentes disciplinas e que, ao mesmo tempo, privilegia a articulação entre as mesmas. Como argumenta Ivan Vilela, "sendo a canção um fenômeno polissêmico que se articula com diversas esferas da vida humana, essa articulação com outros campos do conhecimento é positiva" (VILELA, 2015, p. 67). Tudo isto atentando, é claro, à matéria musical, que prefigura de igual modo parte central das análises, balizando e/ou complementando não só as reflexões concernentes às questões musicológicas, mas também às históricas, sociais, econômicas e culturais.

Por conseguinte, esta dissertação fundamenta-se em uma abordagem e numa análise atentas às dimensões histórico-geográficas, política, econômica, social, literária e musical do

\footnotetext{
${ }^{1}$ A concepção e o entendimento da canção popular como meio para se pensar e interpretar a trajetória de nosso país e, ademais, como índice de processos históricos, receptáculo de experiências históricas e culturais, devo, mormente, a Walter Garcia. Para chegar a tal entendimento da matéria e abordá-la sob tal ponto de vista foram fundamentais o curso "Formas da Canção Popular Brasileira: 1930-1985" (IEB-USP, $1^{\circ}$ sem/2015) e a leitura de GARCIA, 2013.
} 
fonograma selecionado, bem como à de sua inserção e diálogo - e de seus autores e intérpretes - no/com o Brasil pós-1950.

Ao longo da pesquisa foram realizadas exaustivas audições e transcrições do fonograma a fim de perceber e apreender, da forma mais completa possível, o máximo de elementos, características e subtilidades nele inscritos. $\mathrm{O}$ mesmo foi realizado em relação à letra da canção, por meio de obstinadas leituras. Do exercício de escuta e leitura, passou-se ao da descrição e, em seguida, ao do comentário-interpretação, como propôs Antonio Candido (CANDIDO, 2006).

No que concerne à análise interpretativa da canção, David Brackett, em seu livro Interpreting Popular Music, assim escreveu:

lyric analysis has often formed the starting-point for the analysis of popular songs. This may seem to be the obvious place to begin an analysis of a country song, since lyrics occupy a privileged space in the discourse of fans and critics of country music; and the forward placement of the voice in the recorded mix, the 'naturalized', conversational delivery of the lyrics, and their strongly narrative character all work to focus listener attention on the voice. However $[\ldots]$, to analyze lyrics means not to abstract them from their context in a recorded performance; rather, it means to try to understand how lyrics and performances work to create a sense of a particular genre, a particular audience, and a particular relationship between performer and audience. (BRACKETT, 1995, p. 77-78)

Realizada em acordo com essa proposta, a pesquisa em torno de " $\mathrm{O}$ mineiro e o italiano" procurou esgotar, em primeiro lugar e na medida do possível, as possibilidades oferecidas pela letra desta moda de viola. Assim, durante os estudos, as leituras, releituras e o manejo das referências bibliográficas auxiliaram na tarefa de perceber, apontar, descrever e analisar os personagens-tipo e o conteúdo sintetizados pela letra da canção. Isso, sempre com a preocupação de relacioná-los com a cultura caipira e com o processo histórico da Paulistânia. No decorrer dessa empreitada, ao confrontar e interpretar as experiências e as relações sociais evocadas pela composição, a preocupação de dar ênfase às questões ligadas ao acesso e à propriedade da terra na região também esteve presente.

Em um segundo momento, passou-se a investigar de que maneira e em que grau os elementos musicais da obra - bem como aqueles inerentes à interpretação de Tião Carreiro e Pardinho - contribuíam para reforçar (ou enfraquecer) as características (materiais e 
imateriais), os referenciais históricos e culturais e o poder evocativo evidenciados pela letra da canção.

Por fim, situar o fonograma, os compositores e os intérpretes da canção no momento de sua produção, entendendo a composição e o fonograma como objetos pertencentes a uma dada tradição e, ao mesmo tempo, cristalizadores e perpetuadores de dada experiência histórica e cultural, foi atividade que ocupou o terço final deste Mestrado. O esforço em direção à compreensão desta obra em sua historicidade acabou por se desdobrar no conteúdo que deu origem ao primeiro capítulo desta dissertação.

Adotar o caminho descrito nos três últimos parágrafos mostrou-se como o itinerário mais apropriado, posto que, dados a matéria, o tema e os objetivos deste trabalho, uma pesquisa desatenta a todas essas dimensões, em conjunto, esvaziar-se-ia de sentido, pois não supriria adequadamente as demandas analítico-interpretativas do objeto de estudo selecionado. Tampouco contemplaria as questões suscitadas pelo conteúdo que dá sentido e coesão à narrativa (literária e musical) de "O mineiro e o italiano".

A partir do que foi tratado nesta introdução, esta dissertação está estruturada da seguinte forma:

O capítulo I apresenta, de forma sumarizada, a cultura e a música caipira; traz uma síntese da trajetória profissional e artística de Teddy Vieira e de Tião Carreiro e Pardinho; e aborda, resumidamente, a indústria fonográfica e o mercado de canções no período em que o compositor-empresário e a dupla caipira atuaram. Ao longo do capítulo, esses assuntos foram abordados com a intenção de se contextualizar historicamente e justificar a relevância da obra escolhida como objeto de estudo, bem como a fim de antecipar a análise dos aspectos musicais e cancionais de "O mineiro e o italiano".

Os capítulos II e III foram concebidos a partir do empenho de se investigar em que medida esta canção popular pode ser compreendida enquanto síntese do processo histórico e da experiência histórica e cultural da Paulistânia.

Tendo o foco no conteúdo da letra, nos aspectos estético-formais da música e na interpretação da dupla Tião Carreiro e Pardinho, o segundo capítulo aponta, descreve analisa e interpreta os ingredientes contidos ou sugeridos pelo fonograma, sempre os confrontando com aspectos e singularidades da cultura caipira e do processo histórico da Paulistânia. Seu objetivo principal é discutir quem são esses personagens que aparecem na letra, como eles 
são apresentados e representados pela narrativa da canção, o que sintetizam e quais sentidos suas relações produzem. O último item desse capítulo procura demonstrar ou sugerir quais ingredientes essenciais à cultura caipira e de que maneira certas características singularizantes do processo histórico e da experiência da cultura caipira são evocados e sintetizados pelos elementos e estruturas musicais do fonograma da canção.

A partir das questões, definições e argumentos apontados e discutidos pelos capítulos precedentes, o terceiro capítulo tem por objetivo principal cotejar a narrativa da letra de "O mineiro e o italiano" com a historicidade dos meios de acesso e propriedade da terra na região da Paulistânia. Traz, ainda, uma sugestão de cronologia para a história da narrativa.

No coda, são apresentadas as considerações finais, enquanto os anexos trazem transcrições e materiais musicais que podem servir de complemento às análises apresentadas principalmente pelo capítulo II. 


\section{Paulistânia: berço da cultura Caipira}

Paulistânia. Hermes Fontes, em crônicas escritas para o jornal Correio Paulistano entre 1917 e 1918, serviu-se desse vocábulo como sinônimo para São Paulo². No Clube Piratininga $^{3}$ foi título de revista e, para Martins Fontes, de livro ${ }^{4}$. O editor Heitor de Moraes que a Fontes o título soprou: nos ouvidos de Moraes, "Paulistânia" soava como "Terra Paulista", tal qual os portugueses tinham sua Lusitânia e os povos germânicos sua Germânia. De acordo com Carlos Alberto Dória, o termo Paulistânia "fixou-se graças a uma historiografia de cunho conservador, ligada ao espírito provinciano de intelectuais paulistas, querendo definir para a 'raça paulista' um determinado território" (DÓRIA, 2018, p. 69). Ainda segundo esse autor, foi o historiador Alfredo Ellis Júnior que, a partir dos anos 1930, “mais trabalhou o conceito de Paulistânia" (DÓRIA, 2018, p. 69).

Mas foi Joaquim Ribeiro, na obra Folklore dos Bandeirantes, de 1946, quem propôs que Paulistânia era termo seu, um neologismo criado "para designar o espaço vital dos antigos paulistas" (RIBEIRO, 1946, p. 185), um substantivo a ser usado, a partir de então, para se fazer referência à região que, em sua opinião, foi "uma das células fundamentais da formação do Brasil” (RIBEIRO, 1946, p. 13). O autor acreditava que, além de útil, Paulistânia era um nome que expressava uma "compreensão geográfica e histórica da região do bandeirismo" (RIBEIRO, 1946, p. 185).

A expressão "região do bandeirismo", neste caso, refere-se à e delimita a área geográfica percorrida e desbravada pelos bandeirantes que, desde o século XVI até meados do XVIII, "desafiando as insídias de um mundo ignorado e talvez inimigo" (HOLANDA, 1986, p. 26), partiram rumo aos sertões $^{5}$ à busca de índios para escravizar, ouro para enriquecer, reduções jesuíticas ou quilombos para destruir ${ }^{6}$. O mapa a seguir ilustra as rotas

\footnotetext{
${ }^{2}$ A coleção do jornal Correio Paulistano encontra-se disponível para consulta e pesquisa no Arquivo do Estado de São Paulo. A consulta em microfilme compreende o período de 1854 (ano de início da publicação) a 1928.

3 Tendo suas raízes na Revolução Constitucionalista de 1932, o Clube Piratininga foi fundado por famílias tradicionais da aristocracia paulistana, em 16/12/1934, no bairro de Higienópolis, cidade de São Paulo. (fonte: https://www.clubepiratininga.com.br/sobre-nos, consultado em 30/05/2018)

${ }^{4}$ FONTES, 1984.

5 “Sertão, segundo Walnice Galvão, a partir de pesquisas de Gustavo Barroso, já era utilizado na África e Portugal antes do Brasil e não tem o sentido de designar um lugar deserto ou estéril como muitas vezes se supõe, mas sim o de nomear o interior e regiões que estão distantes do litoral" (ARAÚJO, 2014). Para aprofundar-se na discussão sobre significados, usos e questões à volta do termo Sertão ver: BOLLE, 2004; FERRETE, 1985.

6 RIBEIRO, 1995; http://atlas.fgv.br/marcos/bandeiras-e-bandeirantes/mapas/objetivos-das-bandeiras, consultado em 30/05/2018.
} 
dessas bandeiras e entradas e dá a (assustadora) dimensão das distâncias percorridas por aqueles homens:

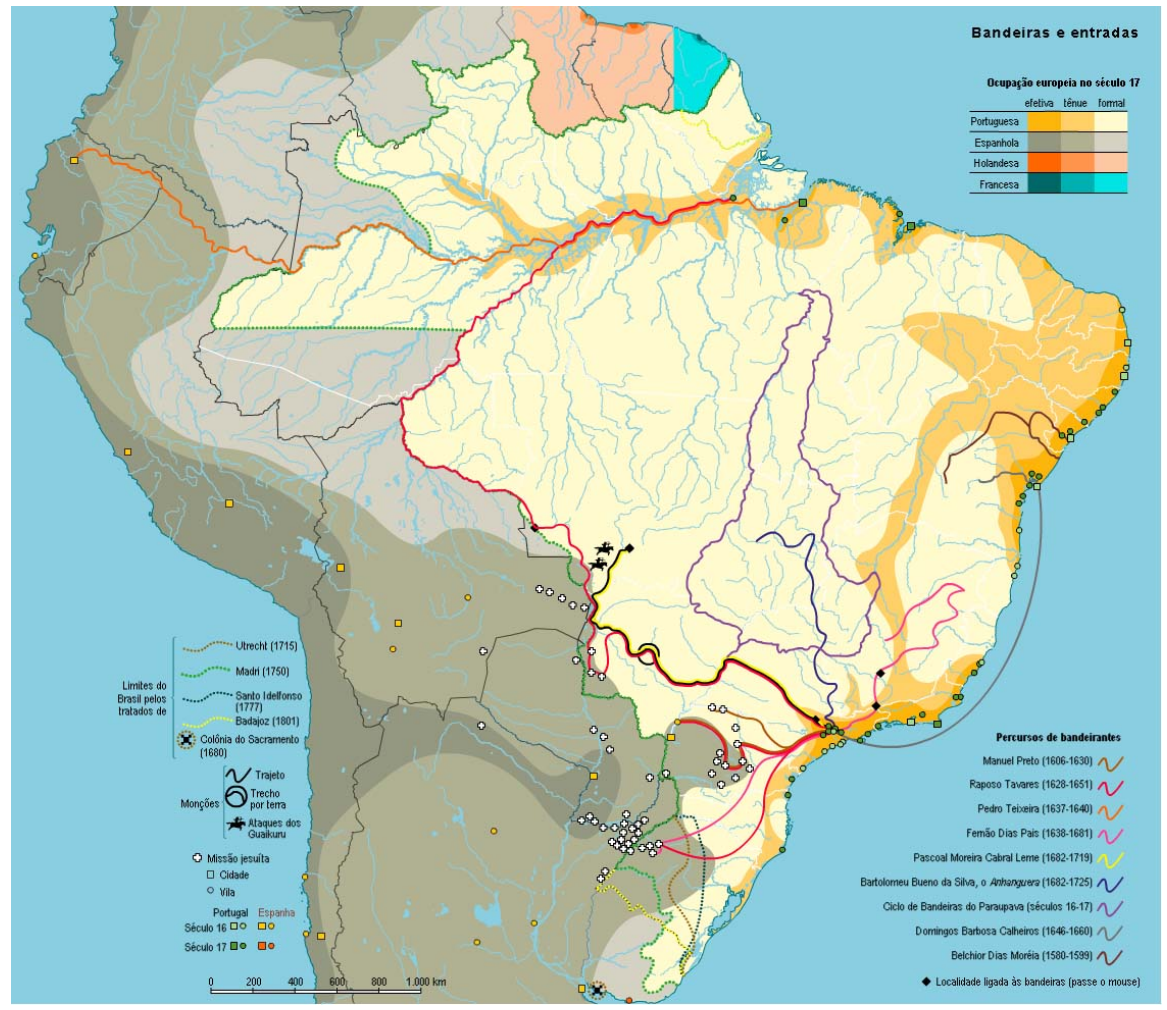

fonte: http://atlas.fgv.br/marcos/bandeiras-e-bandeirantes/mapas/bandeiras-e-entradas

(consultado em 30/05/2018)

Isso representa muito em quilômetros e ousadia: essas incursões ao sertão foram decisivas para a "a expansão do domínio português terra adentro" (RIBEIRO, 1995, p. 106) e contribuíram para dar ao Brasil - em linhas gerais e no sentido Centro-Oeste-Sul - um contorno geográfico bem próximo àquele que hoje se (re)conhece. Ao esgarçar os limites de Tordesilhas (GOES FILHO, 2015, Cap. V), alargando o domínio português em detrimento ao indígena, espanhol ou jesuítico, abriram o caminho para uma ocupação efetiva que ainda tardaria a se concretizar.

Em seu afã, aqueles velhos paulistas, "brasilíndios" e mamelucos como quis Darcy Ribeiro $^{7}$, abraçaram o sertão "desde os campos de Coritiba às serras do Espírito Santo, Bahia, Goiás e campos de Mato Grosso, [dominando] toda a região de Minas Gerais" (RIBEIRO,

\footnotetext{
7 “A expansão do domínio português terra adentro, na constituição do Brasil, é obra dos brasilíndios ou mamelucos. Gerados por pais brancos, a maioria deles lusitanos, sobre mulheres índias, dilataram o domínio português exorbitando a dação de papel de Tordesilhas, excedendo a tudo que se podia esperar" (RIBEIRO, 1995, p. 106).
} 
1995, p. 149). Foram, também, “até as ribanceiras do rio Iguassú, de um lado e do rio Paraná de outro", estiveram na "região alta catarinense, [na] serrana rio-grandense [e na] do vale do médio rio Paraíba", lá no que hoje é território do Estado do Rio de Janeiro (ELLIS JR., 1948, p. 14). Esta, portanto, a "região do bandeirismo":

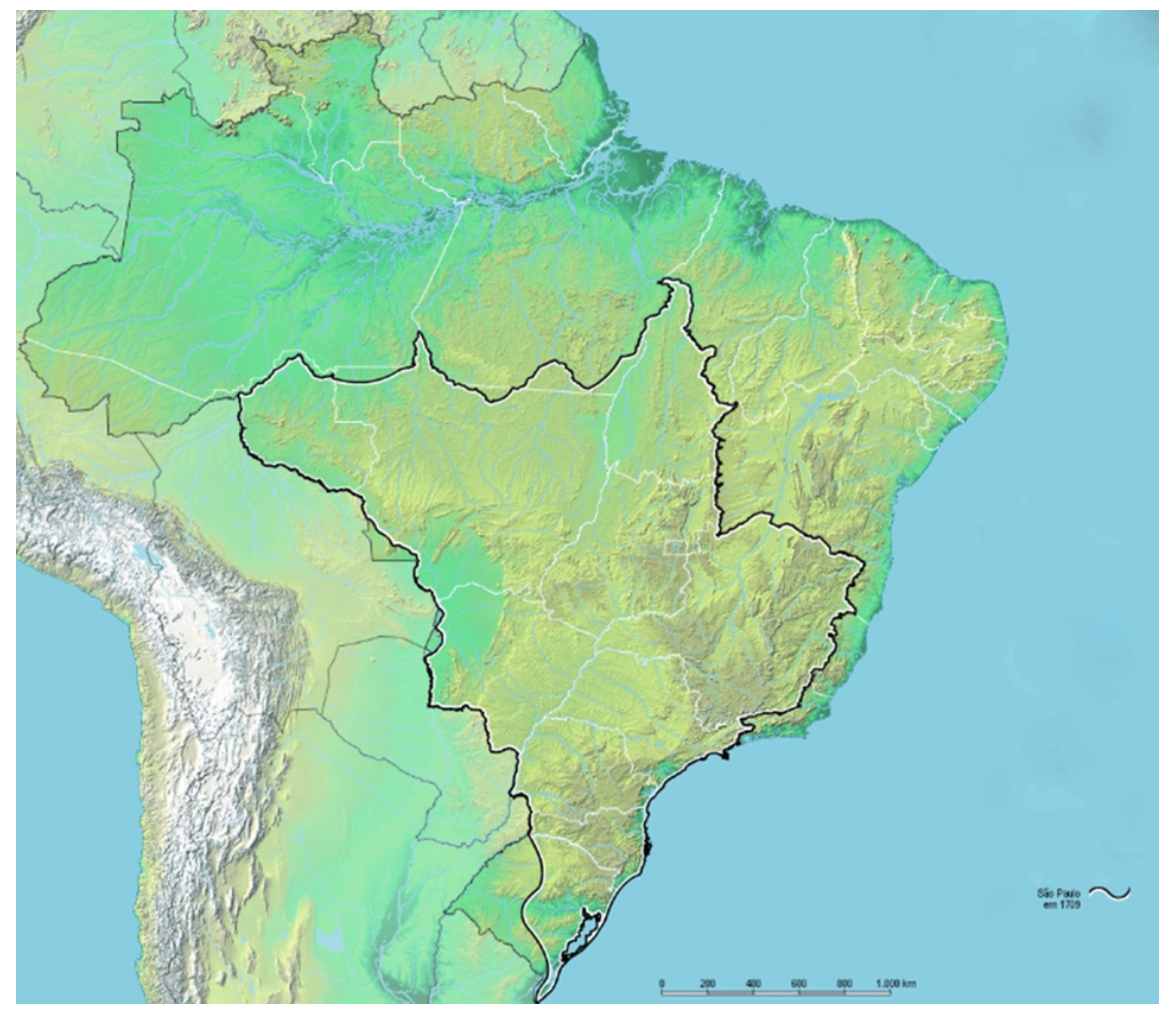

fonte:http://atlas.fgv.br/marcos/descoberta-do-ouro/mapas/o-papel-das-minas-na-unificacao-do-brasil (consultado em 30/05/2018)

Se por meio de um processo histórico que trouxe em si os períodos da preação de índios para escravizar, da busca pelo ouro e da disputa por terras e almas os homens daquela época $^{8}$ deixaram de apenas arranhar o litoral tal e qual caranguejos ${ }^{9}$, seria preciso, contudo, mais tempo e um novo contexto histórico para que essa vasta área geográfica se constituísse, de fato, enquanto uma "Terra Paulista".

Pois o contexto histórico necessário para tanto emergiu no (e traspassou o) século XVIII: com o forte declínio do comércio de escravos indígenas e a descoberta de ouro na área das Minas Gerais, as atividades que impulsionavam as incursões bandeirantes pelo interior extinguiram-se, gerando "estagnação e decadência" (PRADO Jr., 2011, p. 68-69) e

\footnotetext{
${ }^{8}$ Séculos XVI e, principalmente, XVII.

${ }^{9}$ SALVADOR, s/d.
} 
promovendo, em praticamente toda a área de sua expansão, uma "fixação generalizada do paulista ao solo" (CANDIDO, 2001, p. 103). Uma vez assentada, aquela população de famigerados ${ }^{10}$ foi, paulatinamente, tomando posse de terras, cultivando roças mais perenes ${ }^{11}$, criando animais para fins de abate, ordenha ou transporte, erigindo espaços comuns de culto e lazer, formando bairros rurais, pequenas vilas, "freguesias, povoações e fazendolas" (DÓRIA, 2018, p. 85). Isso tudo porque, se na Paulistânia o início do século XVIII foi marcado por sedentarização, paralisia, declínio e esvaziamento demográfico - este causado pelas vultuosas migrações em direção às minas (FURTADO, 2007, p.118; DÓRIA, 2018, p. 85 ) -, o passar de suas décadas revelou-se promissor para a região: um potencial mercado consumidor surgiu tão logo a "economia mineira" começou a operar (FRAGOSO, 1998, p. $59,60,73-74)$.

Em virtude da alta lucratividade do negócio, houve "excessiva concentração de recursos nos trabalhos mineratórios" (FURTADO, 2007, p.118) e, graças a essa, a produção de bens alimentícios ficou prejudicada. Somado a isso, era fato que "a população mineira dependia para tudo de um complexo sistema de transporte" (FURTADO, 2007, p.122). Sem condições de se autoabastecer, a região mineradora acabou por fomentar, nas áreas que a circundavam, o desenvolvimento de atividades ligadas à produção e ao comércio de gêneros alimentícios e de animais (FRANCO, 1997, p. 34). Originalmente e em sua maioria, esses produtores e comerciantes eram "os negros e mulatos forros e os brancos mais pobres" sitiantes pequenos proprietários ou posseiros, "incapazes de entrar no negócio das lavras" que exigia o investimento de grandes capitais (RIBEIRO, 1995, p. 378) - e os tropeiros. Em comum, a maioria, após o fim dos ciclos bandeirantes, havia se estabelecido nas rotas para as minas ou nas regiões periféricas às da mineração (SCATIMBURGO, 2006, p. 191; CANDIDO, 2001, p. 103; FRAGOSO, 1998, p. 60). Durante todo o Setecentos, destarte, a região paulistânica permaneceu "ligada ao abastecimento das minas", com "inúmeras áreas dedicadas à produção de alimentos" e animais para estas (FRAGOSO, 1998, pp. 71 e 74). Nesse contexto, abria-se ao homem pobre a "perspectiva de acumulação de capital" (FRAGOSO, 1998, p. 69). A parcela que nas minas encontrou seu Eldorado - não no ouro, mas na produção agrícola ou pecuária, ou, ainda, no comércio -, engendrou uma nova classe

\footnotetext{
${ }^{10}$ ver: RIBEIRO, 1995, p. 106 e HOLANDA, 1986, p. 26.

${ }^{11}$ No início, mais perenes se comparadas àquelas cultivadas pelos bandeirantes; mas, pelo menos até o último quartel do século XVIII, não suficientemente duradouras para mitigar o caráter seminômade da grande maioria daquela população.
} 
de fazendeiros e comerciantes que em pouco mais de meio século comporia uma nova e poderosa elite.

Ora, se o conceito de experiência histórica e cultural serve, antes de mais nada, "para que os historiadores [percebam] que não é possível pensar determinada classe social separada da outra” (THOMPSON apud MELO Jr., 2011, p. 3), é neste sentido que se deve observar que, paralelamente aos núcleos isolados e autossuficientes que se organizavam e viviam sob as "formas mínimas de ajustamento" das quais fala Antonio Candido (CANDIDO, 2001, p. 107), floresceram "setores da sociedade que se organizaram para a produção mercantil" (FRANCO, 1997, p. 34). É fato que o rápido aumento da demanda, aliado à escassez da oferta, ao mesmo tempo em que gerou um processo inflacionário (SAMPAIO, 2014, p. 309), desencadeou a "irradiação dos benefícios econômicos da mineração" para suas regiões vizinhas (FURTADO, 2007, p.121), criando um cenário em que "o efeito multiplicador da mineração foi evidente" (FRAGOSO, 1998, p. 71).

Se, "durante o auge da mineração, a venda de mantimentos e outros produtos aos mineradores propiciou a formação de grandes fortunas" (LOPES, 2008, p. 195) e, consequentemente, uma parte da classe de sitiantes grassou sua ascensão econômica e social, uma multidão de outros não partilhou dessa sorte. Com o declínio da mineração, em fins do século XVIII, parte da população que havia deixado a Paulistânia em busca do Eldorado realizou sua migração de retorno (PRADO Jr., 2011, p. 78, 81, 82 e 84). Em sua maioria, voltaram como foram: pobres, a viver sob condições rústicas, com soluções mínimas em um sistema de subsistência baseado na posse da terra ou na pequena propriedade. Nesse cenário, muitos dos sítios que se distribuíam

pelos antigos caminhos das minas, e outros que articulavam os sertões da Paulistânia [...] tornaram-se unidades de subsistência familiar, às vezes formando bairros rurais, um conjunto de sítios, não raro de parentes ou compadres, que só saiam para ir às vilas mais próximas quando precisavam de serviços da justiça, para ir à igreja ou em datas festivas, como quermesses ou celebrações do calendário católico. (DÓRIA, 2018, p. 98)

Esta população vivia, assim, "na maior parte do tempo [entregue] a afazeres ligados às criações e às culturas agrícolas básicas, provendo-se de quase tudo e recorrendo aos vizinhos para fazer mutirões nos roçados ou auxiliar na matança do porco" (DÓRIA, 2018, p. 98-99). 
Assim, tem-se que, do movimento inicial do bandeirante, de sua posterior fixação e do desenrolar do processo histórico da Paulistânia, "foi se moldando uma cultura peculiar em seus vários aspectos” (VILELA 2015, p. 153), que não só se desenvolveu como também se conservou ao longo do tempo (CANDIDO, 2001, p. 45 e 102; VILELA 2015, p. 153-155). Com "formas de sociabilidade que se apoiavam [...] em soluções mínimas, apenas suficientes para manter a vida dos indivíduos" e sua coesão social enquanto grupo (CANDIDO, 2001, p. 103), vivendo em comunidades isoladas e autossuficientes, de economia fechada e de subsistência (FURTADO, 2007, p. 218; CANDIDO, 2001, p. 45, 75 e 108; FRANCO, 1997, p. 33), ao fixar-se essa gente deu origem ao que viria a ser o grosso da população de homens livres e pobres daqueles territórios, com "estilo de vida específico", "integridade de cultura e de organização social" (FRANCO, 1997, p. 33).

Consolidando-se historicamente como o berço dessa cultura, cada vez mais aquele imenso território da Paulistânia se tornava o "espaço vital dos paulistas", paulatinamente, foi surgindo e sendo criada, sendo criada e surgindo, uma região geográfica ${ }^{13}$ que, findo o ciclo dos bandeirantes, "fez com que se espraiasse pela capitania, até os limites do povoamento, uma população geralmente marcada pelas características acima definidas" (CANDIDO, 2001, p. 103).

Por corolário, esse processo histórico engendrou uma verdadeira tessitura cultural que, de mais a mais, se fez comum à grande maioria dos habitantes da vasta região da Paulistânia (ainda que a comunicação entre diferentes núcleos fosse precária ou nula). Como afirmou Antonio Candido,

\footnotetext{
12 "De fato, o desenvolvimento do tempo como duração social incorpora o espaço à história dos grupos e evidencia os diferentes aspectos da solidariedade de ambos. $\mathrm{O}$ espaço se incorpora à sociedade por meio do trabalho e da técnica, que o transformam sem cessar e o definem [...]" (CANDIDO, 2001, p. 30).

${ }^{13}$ Região Geográfica, aqui, enquanto conceito cunhado pela Geografia Humanista: “[...] a região, portanto, [é entendida] não como constituindo uma realidade objetiva; ao contrário, ela foi concebida como uma construção mental, individual, mas também submetida à subjetividade coletiva de um grupo social, por assim dizer, inscrita na consciência coletiva. [De acordo com a Geografia Humanista, a região] "não se confunde com espaços sociais cotidianos, com os lugares pontuais nem com os grandes espaços. [Situa-se, antes] numa escala intermediária, definida segundo a rede de relações que os indivíduos tecem de acordo com os lugares mais frequentados por um determinado grupo social" (LENCIONI, 2003, p.155-156). Como se pode inferir, "nessa concepção a região é encarada como espaço vivido e não unicamente como espaço material com limites fixos à medida que leva em consideração valores psicológicos que as pessoas têm em relação à região" (VIEIRA, 2014, p. 25). Assim, esta perspectiva historicista da Geografia considera a região como "um espaço que é o produto da história e da cultura" (LECIOLI, 2003 p. 154). Neste contexto, a análise regional extrapola a investigação que se restringe às divisões e traçados estritos da Geografia Politica, levando em consideração as "fronteiras" culturais em maior grau do que aquelas políticas, físicas, procurando analisar, também, os aspectos subjetivos da região (LECIOLI, 2003, p. 156). Sobre correntes e conceitos da Geografia ver: BECKER, 2012, GOMES (s/d), CORRÊA, 2003, p. 49-76.
} 
[...] em certas porções do grande território devassado pelas bandeiras e entradas - já denominado significativamente Paulistânia - as características iniciais do vicentino se desdobraram numa variedade subcultural do tronco português, que se pode chamar de 'cultura caipira'. (CANDIDO, 2001, p. 45)

Isso posto, pode-se dizer que, a partir de meados do século XVIII, espalhou-se e consolidou-se "um lençol de cultura caipira, com variações locais, que abrangia [além da capitania paulista] partes das capitanias de Minas, Goiás e mesmo Mato Grosso" (CANDIDO, 2001, p. 45). Atualizando a geografia, não seria exagero afirmar-se que o traçado da cultura caipira se expandiu e abrangeu as áreas que hoje correspondem aos Estados de São Paulo, Minas Gerais, Goiás, Mato Grosso, Mato Grosso do Sul, Paraná, Santa Catarina, parte do Rio de Janeiro e Espírito Santo e a região das Missões, no Rio Grande do Sul (DÓRIA, 2018, p. 34).

Por conseguinte, em todas estas áreas observavam-se variações das "mesmas práticas festivas, a mesma literatura oral, a mesma organização da família, os mesmos processos agrícolas, o mesmo equipamento material" (CANDIDO, 2001, p. 108), as mesmas soluções alimentares (DÓRIA, 2018, p. 34). Indo além, é seguro afirmar que, a despeito dos diferentes recortes que a geografia política impôs à região paulistânica - seja durante o Período Colonial, o Império ou a República -, nesta grande área desenvolveu-se e perpetuou-se aquilo que se pode considerar como essencial e específico à cultura caipira. Mudavam-se os mapas, as fronteiras, conservavam-se os hábitos, os fazeres. Esse fato é verificável - como demonstraram Carlos Alberto Dória, Ivan Vilela, Amadeu Amaral, Osvaldo Elias Xidieh, Antonio Candido $^{14}$ - tanto na culinária quanto na música, no jeito de falar e nas práticas religiosas, nos costumes e no modo de produção; enfim, nas maneiras de ser, ver e existir daquela população.

Ainda sobre os desdobramentos e particularidades do processo histórico referente à cultura caipira, Antonio Candido observa que

o deslocamento incessante do bandeirismo prolongou-se de certo modo na agricultura itinerante, nas atividades de coleta, caça e pesca, do descendente caipira, a partir do século XVIII. As técnicas rudimentares, a cultura

\footnotetext{
${ }^{14}$ DÓRIA, 2018; VILELA, 2015; AMARAL, 1920; XIDIEH, 1967; CANDIDO, 2001.
} 
improvisada do nômade encontraram [no caipira] condições para sobreviver. (CANDIDO, 2001, p. 57)

Logo, o Setecentos pode ser considerado como um "momento crítico da história paulista" - bem como para toda a área sob sua influência, a Paulistânia. Segundo Candido, foi neste momento, "quando a sedentarização se impôs de modo geral, requerendo a reorganização dos hábitos e a redefinição dos valores sociais mais prezados, [que] parecem haver-se configurado os traços fundamentais da cultura caipira” (CANDIDO, 2001, p. 111). Com um contingente populacional majoritariamente "constituído por pequenos agricultores livres (DÓRIA, 2018, p. 35; CANDIDO, 2001), do século XIX até a primeira metade do século XX, "a cultura caipira persistiu na figura de sitiantes, posseiros e agregados" (VILELA, 2015, p. 153). E, tal e qual sua culinária - a exemplo de todas aquelas que se baseiam na produção para a subsistência -, durou "até que a malha urbana se [consolidasse], os transportes se [desenvolvessem] e [que a dominação] do campo pela cidade [começasse] (DÓRIA, 2018, p. 45). Na Paulistânia e para sua cultura sui generis, o ocaso "aconteceu a partir do ciclo do café e da penetração ferroviária” (DÓRIA, 2018, p. 45), aproximadamente no período de cem anos que vai de 1850 a 1950. Iniciado o século XX, "os valores do mundo caipira foram desaparecendo gradativamente, perdendo sua função em um mundo que se modernizava" (VILELA, 2015, p. 24).

Em suma, e na boa síntese oferecida por Carlos Alberto Dória, a Paulistânia

é o vasto território de ocupação original bandeirante - que triplicou a área da colônia americana reservada a Portugal pelo Tratado de Tordesilhas, de 1494, em comparação ao Tratado de Madri, de 1750 -, onde se formou uma sociedade bastante distinta das demais áreas de ocupação do Brasil, com baixa participação das etnias negras, e que se consolidou basicamente através da economia de subsistência. Mais do que um território fechado, a Paulistânia foi um tecido de caminhos que se entrecruzaram, formando uma rede tênue que cobria das Missões guaranis ao médio rio São Francisco, das fronteiras do Paraguai e das minas de Corumbá a São Vicente, de Vacaria à feira de muares de Sorocaba, [e que teve no caipira] o tipo humano que resultou desse longo processo de expansão territorial [que unificou] populações muito distantes entre si. (DÓRIA, 2018, p. 72) 


\subsection{Música dos caipiras, música caipira, música sertaneja: do folclore ao disco}

Nessa região e dessa cultura nasceu "uma modalidade especial de música popular", a qual Alberto Ikeda considerou como sendo "a música da Paulistânia" ". Nas palavras do autor, trata-se de "uma música que se relaciona à própria formação histórica de São Paulo, singularizando-se como paulista" (IKEDA, 2004, p.142). Para Ikeda,

quando buscamos alguma identidade, sobretudo do interior, chegamos certamente à música popular de tradição oral, que tem na viola caipira o seu símbolo maior. Surgida na gênese dessa formação histórica, a chamada música caipira se expandiu por um amplo território por vezes designado como Paulistânia. (IKEDA, 2004, p.142)

Para além de símbolo, a viola caipira foi fiadora da expansão desta música dos caipiras. Configurando-se como porta-voz desta musicalidade, o instrumento se espalhou por toda a Paulistânia e, tendo sua identificação “com os primeiros habitantes da região [fortalecida] à medida que o tempo passou", chegou ao ponto de fazer do violeiro um “indivíduo de grande importância na comunidade onde [habitasse] (VILELA, 2015, p. 45). Na opinião de Ivan Vilela, "o fato de encontrarmos a viola na região da Paulistânia denota o quanto foi um instrumento presente na cultura bandeirante, e posteriormente tropeira, a ponto de se firmar como elemento cultural nos espaços onde andaram e se fixaram as bandeiras" (VILELA, 2015, p. 42). Rosa Nepomuceno vai além (e talvez exagere...), ao considerar a viola como “o coração da música brasileira” (NEPOMUCENO, 1999, p. 55).

No que concerne ao processo de formação da música dos caipiras, este remonta, na visão de Ivan Vilela, aos tempos do início da colonização do Brasil, tendo esta manifestação

\footnotetext{
${ }^{15}$ Música da Paulistânia, música dos caipiras, música caipira, música sertaneja, música sertaneja tradicional, música sertaneja de raiz, música caipira de raiz, música de moda de viola... Nomenclaturas (e argumentos) não faltam para tentar dar conta da "heterogênea unidade" que caracteriza esse segmento da música popular brasileira. Foge ao foco e ultrapassa os limites deste trabalho discutir os porquês, a validade e acuidade de todas essas nomenclaturas alcunhadas pelo tempo, artistas, indústria, mercado, imprensa, críticos, estudiosos, acadêmicos. O debate em torno dessa questão é profícuo, interessante e longo, com boas sínteses produzidas por diferentes autores. De todo modo, ao longo desta dissertação os termos listados no início desta nota referir-seão, de modo genérico, à "música da Paulistânia" - ou, no limite, às músicas que dela se originaram, derivaram, ou nela se inspiraram. Sem desconsiderar, evidentemente, suas vicissitudes, diferentes fases, desdobramentos, desmembramentos, enfim, seu processo histórico-cultural (e a literatura sobre ele), essas expressões serão aqui utilizadas - na maioria das vezes - como sinônimos. Isso porque, de acordo com os propósitos desta dissertação, e em relação aos assuntos e questões abordados por ela, a aplicação desses termos enquanto sinônimos não acarreta em prejuízo analítico nem gera confusão, contradições ou ambiguidades dignas de nota.
} 
musical se estruturado tal qual viemos a conhecê-la, porém, entre os séculos XVIII e XX (VILELA, 2015, p. 151).

Plural, esta música configurou-se como "o maior guarda-chuva de ritmos distintos existente na música brasileira" (VILELA, 2015, p. 71). Conforme descreveu José Hamilton Ribeiro no livro "Música Caipira: as 270 maiores modas", o violeiro Cacique (da dupla Cacique e Pajé) era capaz de tocar, sem esforço, "13 ritmos da música caipira, cada um independente e diferente do outro" (RIBEIRO, 2015, p. 279). Neste mesmo livro é apresentada uma lista de vinte e dois "ritmos caipiras". Elaborado por Simone Sperança, este "catálogo de ritmos caipiras" apresenta "a célula rítmica predominante" de cada ritmo ao mesmo tempo em que indica exemplos de fonogramas onde os mesmos podem ser ouvidos. Compõem a lista: arrasta-pé, cana verde, querumana, canção rancheira, valseado, valsa, cateretê, cururu, corta-jaca, lundu, toada, moda de viola, rasqueado, pagode de viola, recortado, guarânia, moda campeira, chibata, chamané, batidão, polca e xote (RIBEIRO, 2015, p. 280-306).

Como se pode observar - e a literatura sobre o assunto confirma -, muitos destes ritmos que figuram na lista de Sperança como "ritmos caipiras" têm origem, estão ligados ou relacionam-se (também) a outras regiões e culturas (i.e. lundu, polca, valsa, corta-jaca, chamané). Nesta mesma perspectiva, Lucas Antonio Araújo afirma que “a própria polca paraguaia e a guarânia, assim como o bolero, são identificados como gêneros pertencentes ao conjunto da "música sertaneja de raiz" (ARAÚJO, 2014, p. 204). Voltando à lista de Simone Sperança, sublinha-se, ainda, que esta apresenta como ritmos alguns exemplos que são, na verdade, partes da forma musical de um gênero específico, como no caso do recortado, elemento formal obrigatório do gênero moda de viola ${ }^{16}$.

Acontece que, ao não ter a pretensão de "realizar cortes profundos na origem desses ritmos, mas sim relacioná-los e indicar a exclusiva célula rítmica de cada um" - obtida por meio da análise da "configuração melódica" das composições consideradas como exemplos , a lista da pesquisadora pode gerar confusão ou levar a mal-entendidos (RIBEIRO, 2015, p. 280). Por outro lado, o catálogo de Sperança, de certa forma e em alguns pontos, acaba por reafirmar o fato, observado por Ikeda, de que "a partir das expressões culturais caipiras mais antigas, cada uma dessas regiões [da vasta Paulistânia] foi firmando processos culturalmusicais próprios, de múltiplas influências" (IKEDA, 2004, p. 144).

\footnotetext{
${ }^{16}$ Sobre este assunto ver FAUSTINO, 2016.
} 
Ainda sobre a questão dos ritmos caipiras, vale ressaltar que, de acordo com Lucas Antonio Araújo, esses "estão relacionados em certa medida ao conteúdo das letras" e que "a moda de viola é um ritmo que está entre aqueles mais característicos da música sertaneja tradicional, que muitas vezes é definida simplesmente como "moda de viola" (ARAÚJO, 2014, p.129). Donde o autor concluir que as "modas de viola [são] vistas como a forma mais antiga da música sertaneja tradicional, bem como representante musical máxima da tradição" (ARAÚJO, 2014, p. 239) ${ }^{17}$.

Indo além, pode-se afirmar que, a partir de suas próprias vicissitudes, bem como do processo musical e histórico-social a eles inerente, parte desses "ritmos caipiras" acabou sendo estilizado, dando origem a gêneros musicais autônomos. Conforme escreveu Ikeda,

embora a música caipira esteja predominantemente relacionada a outras expressões [...], alguns ritmos acabaram se fixando também de forma autônoma, como gênero musical em si, predominantemente para a audição, como expressão musical popular de espetáculo (concerto), com autoria reconhecida e expressa. Entre eles se incluem: o cururu, o catira, o arrastapé (polca) e o xótis (xote), que originalmente são formas dançadas, com cantorias muitas vezes de improviso; a toada e a moda de viola, gêneros apenas vocais, e, finalmente, o pagode caipira, inicialmente um tipo de música instrumental solista, de grande virtuosismo, executado na viola caipira, e que passou a ser apresentado também na versão cantada. (Ikeda, 2004, p. 151-152)

Sobre este processo, José Roberto Zan, no artigo "Tradição e assimilação na música sertaneja" $" 18$, observa que

por volta dos anos de 1910, época em que a indústria do disco começava a se implantar no Brasil, já se falava em canção sertaneja para designar composições resultantes de estilizações de ritmos e gêneros musicais de origem rural como modas, toadas, cateretês, emboladas etc.

\footnotetext{
${ }^{17}$ Corroborando esta afirmação, Jairo Severiano escreve que "a moda de viola é a expressão musical maior do artista caipira" (SEVERIANO, 2013, p. 235).

${ }^{18}$ ZAN, 2004.
} 
Em seguida, já na década de 1920, conforme escreveram Jairo Severiano e Zuza Homem de Mello, proliferou-se "uma onda de canções sobre motivos sertanejos" (SEVERIANO, 2015, p. 93).

Fenômeno indissociável deste processo, a música dos caipiras - já desdobrada em gêneros autônomos e reconhecíveis -, paulatinamente passou a fazer parte do imenso guardachuva de ritmos e gêneros que, à época, o termo "música sertaneja" englobava ${ }^{19}$.

Ocorre que, se desde o final do século XIX é possível notar-se, em diferentes áreas artísticas e geográficas, um interesse por temas regionais (os da cultura caipira inclusos) ${ }^{20}$, e de ter havido uma "verdadeira explosão de caipirismo [...] durante [o] período da Primeira Grande Guerra" (TINHORÃO, 2013, p. 214), seria necessário esperar até que "a novidade dos grupos sertanejos nordestinos [perdesse] a força, após mais de dez anos de atuação, [para que] os gêneros de música da região centro-sul [pudessem] fazer sua entrada no cenário da música urbana" (TINHORÃO, 2013, p. 240).

Assim, se "historicamente, a música caipira começou a ser evidenciada no cenário cultural brasileiro a partir da capital paulista, sobretudo da década de 1910 em diante, tendo no escritor, produtor e apresentador-humorista Cornélio Pires (1884-1958) [...] um dos divulgadores pioneiros"21 (IKEDA, 2004, p. 152), foi com o advento do rádio e a "sobrevinda [da] era do disco [que] toda essa riqueza musical e toda essa experiência de vida comunitária [chegaram] aos ouvidos de milhares de migrantes naquele Brasil em movimento, tal como viria a acontecer nas décadas de 1930 a 1960” (BOSI, apud VILELA, 2015, p. 18 - prefácio).

Conclui-se, portanto, que

esses gêneros estão relacionados com a fixação da chamada música sertaneja, a partir da década de 1930, quando a música caipira passou a fazer

\footnotetext{
${ }^{19}$ Sobre o assunto ver TINHORÃO, 2013, p. 211-250 e SEVERIANO, 2015, p. 234-247.

${ }^{20}$ Conforme escreveu Alberto Ikeda, "é importante lembrar que desde o final do século XIX se manifestava em São Paulo o interesse por temas regionais. A iniciativa coube ao escritor Valdomiro Silveira (1873-1941), nascido em Cachoeira Paulista, no Vale do Paraíba, que publicou em 1894 o conto regionalista "Rabicho", considerado iniciador desse movimento entre nós. A partir daí outros contos foram publicados, focalizando aspectos da vida "da roça". Essa temática se revelava para além da literatura, alcançando também expressões como o teatro e as artes plásticas. Neste último caso, podemos lembrar das pinturas do ituano José Ferraz de Almeida Júnior (1850-1899), retratando a vida rural interiorana, incluindo: "Caipira picando fumo" (1893), “Cozinha caipira" (1895), "Apertando o lombilho" (1895), "Violeiro" (1899) e outras. A "descoberta" da música tradicional paulista vem no bojo desse processo de valorização regional” (IKEDA, 2004, p. 152). Camila Koshiba Gonçalves também chama a atenção para este fato (GONÇALVES, 2013, p. 229, nota de rodapé $n^{\circ} 40$ e p. 297).

${ }^{21}$ Sobre Cornélio Pires e as primeiras gravações de música caipira ver GONZÁLEZ, 2018; GONÇALVES, 2013; TINHORÃO, 2013 e MANOEL, 2016.
} 
parte do sistema de comunicação massiva, por meio das gravações em discos e da divulgação nas rádios, inserida no processo de mercantilização da música popular, em que ela se torna um produto de consumo, como expressão de música-espetáculo. (Ikeda, 2004, p. 151-152)

Desse modo, se "as bandeiras contribuíram para a disseminação da cultura caipira e consequentemente de sua música" (VILELA, 2015, p. 61), o disco e o rádio foram grandes divulgadores desta, possibilitando, ao mesmo tempo, que essa música fosse aceita e reconhecida por um número cada vez maior de pessoas, permeando diferentes classes sociais e caindo no gosto de setores da sociedade que até então a "escutavam com receio e desdém" (GONÇALVES, 2013, p. 163 e 113). Contando e (re)inventando o dia-a-dia do caipira e sua cultura, pelas ondas do rádio, sons de gramofones, vitrolas e afins, grande parte daquela pluralidade musical paulistânica ficou registrada em fonogramas, chegou aos ouvidos de um público cada vez maior e transformou a música caipira em "um dos filões que mais venderam na história do disco no Brasil" (VILELA, 2010, p. 336).

É consenso, entre diferentes autores, que o ano de 1929 e as gravações idealizadas e financiadas por Cornélio Pires constituem-se como marcos para "a música da Paulistânia"22. O que gera controvérsia, no entanto, é o significado desses marcos. Ao passo que uns os compreendem como balizas que sinalizam "o nascimento da música sertaneja", outros os consideram como pontos que decretam “o óbito da música caipira”. O debate é longo, interessante e, a seu respeito, há boas sínteses. À guisa de exemplo, cita-se o objetivo e esclarecedor texto de Geni Rosa Duarte, “A música caipira e sua incorporação ao universo radiofônico (São Paulo - 1920-1950)"²3. Em linhas gerais, o que informa (e inflama) este debate são questões relativas às características, relações, semelhanças e diferenças entre a "música folclórica" e a "música popular"; àquilo que pode ser considerado como autêntico e com aura em oposição ao que deve ser encarado como ilegítimo, artificial; ao lugar da tradição versus incorporação/apropriação; ao que é preciso ser compreendido enquanto manifestação histórico-sócio-cultural e ao que só pode ser percebido como fruto da indústria

\footnotetext{
22 GONÇALVES, 2013; VICENTE, 2014. VILELA, 2015; SEVERIANO, 2013; FAUSTINO, 2016; TINHORÃO, 2013; ZAN, 2004; GONZÁLEZ, 2018; ARAÚJO, 2014; NEPOMUCENO, 1999; CALDAS, 1979; ULHÔA, 1999.

${ }^{23}$ DUARTE, 2006, p. 105-125.
} 
cultural, enquanto mercadoria; aos contrastes e assimetrias contidos nos binômios "moderno $x$ arcaico", "de raiz $x$ adventício"; ao que urge ser valorizado em contrapartida àquilo que deve ser desprestigiado.

Para o foco, propósitos e limites deste trabalho, não se faz necessário aprofundar-se ou demorar-se (em demasia) nestas discussões. Cabe, todavia, delinear alguns pontos e evidenciar algumas posições.

Se "a música caipira foi um filão importante para a indústria do disco ao longo de todo o século XX" (GONÇALVES, 2013, p. 244), é preciso lembrar-se que, quando esta música dos caipiras chegou ao disco, em 1929, encontrou uma indústria fonográfica ainda incipiente e um mercado consumidor em formação (DIAS, 2008; GONÇALVES, 2013, p. 127; VICENTE, 2014). Em razão e consequência disso, e uma vez que "a indústria fonográfica brasileira [seguiu] caminhos muito particulares, apresentando forte vinculação a manifestações culturais locais" (DIAS, 2008, p. 35), mesmo que, indubitavelmente, "a partir [de] sua apropriação pela indústria fonográfica, a música sertaneja sofrerá um crescente desenraizamento, autonomizando-se, perdendo muitas de suas características originais e passando a responder, de modo cada vez mais intenso, às solicitações do mercado" (VICENTE, 2014, p. 108), também é certo que as gravadoras, no caso de São Paulo, "se adequaram ao mercado musical paulistano incorporando as sonoridades existentes, ainda arraigadas às condições tradicionais de difusão da música - via oralidade, teatro de variedades, festas populares" (GONÇALVES, 2013, p 23).

É no âmbito deste diálogo que se deve compreender que

para além dos objetivos de lucratividade da indústria fonográfica e do salto tecnológico que elas promoveram a partir da gravação elétrica, o disco também estava inserido em uma 'tradição musical' pré-existente, com a qual ele foi obrigado a dialogar, interagir, apropriar-se, ou mesmo, recriar. (GONÇALVES, 2013, p. 315)

É também no bojo desta historicidade que, como observou José Geraldo Vinci de Moraes, é preciso apreender-se que

se, a princípio a geração e criação dessas canções não era destinada ao mercado, gradativamente elas incorporaram-se a ele; [...] e, finalmente, a canção é obrigada a dialogar de diversas maneiras, positiva e negativamente, 
com os meios de comunicação eletroeletrônicos. (MORAES apud GONÇALVES, 2013, p 61)

Nesse contexto, ainda que, historicamente, "a integração [de diferentes] modalidades de música popular à indústria fonográfica e aos meios de comunicação de massa impôs mudanças na maneira como eram criadas, nos seus aspectos formais e até mesmo na recepção das músicas por parte do público" (ZAN, 2004, p. 5), no que concerne à música dos caipiras é possível afirmar seguramente que, ao menos em sua fase inicial e no que tange os aspectos composicionais, formais, interpretativos, as modificações impostas por esta incorporação não foram de grande monta. Conforme escreveu Camila Koshiba Gonçalves,

não existem registros escritos que se contraponham satisfatoriamente à ideia preliminar de que a principal característica dessas 'duplas pioneiras', cujo núcleo central foi a Turma Caipira de Cornélio Pires e a da Victor, seja o registro 'fiel' daquilo que os caipiras comumente realizavam na 'roça'. A audição de centenas de gravações também não permite afirmar com segurança se houve uma operação para transformar as gravações das 'modinhas' de viola em discos 78rpm em algo mais palatável ao ouvinte. (GONÇALVES, 2013, p. 270)

[...] recrutados "diretamente" do interior de São Paulo, [aqueles artistas pioneiros] faziam "tudo bem ensaiado" no estúdio, exatamente da forma que costumavam fazer em suas festas, e as gravações, sempre realizadas com poucos cantores, no máximo com duas violas, e com sonoridades bastante semelhantes entre si, talvez dessem pouco trabalho ao engenheiro de som ou ao diretor artístico da gravadora. (GONÇALVES, 2013, p. 268)

Nessas pioneiras gravações da música dos caipiras, portanto, “aparentemente, a única forma de interferência da gravadora no registro sonoro seria cortar algumas quadrinhas, para que a canção coubesse nos três minutos do disco, e exigir que o caboclo permanecesse parado diante do microfone" (GONÇALVES, 2013, p. 269). Sobre este "cortar algumas quadrinhas" e as mudanças formais sofridas pela música dos caipiras quando esta chegou ao disco, Ivan Vilela afirma que

Cornélio [Pires], realizando essas gravações [pioneiras], trouxe a cultura oral, falada e cantada, para o formato do disco. Para se encaixar no tempo de 
reprodução que um disco 78 rpm permitia, os causos e romances tiveram de ser diminuídos. Processou-se, então, um corte, uma nova formatação do longo romance. Quais estrofes seriam mantidas? Cornélio foi quem primeiro configurou esse novo formato da música dos caipiras. (VILELA, 2010, p. 98)

Isso posto, é válido afirmar que as modificações e/ou transformações (se e quando existiram) não foram tão longe a ponto de descaracterizarem ou converterem em "outra música" aquelas modas de viola, cururus, cateretês, contradanças, valsas e choros, gravados nos cerca de 50 discos da série vinte mil (20.000) de selo vermelho de Cornélio Pires (GONÇALVES, 2013, p. 258). Neste mesmo sentido, as modificações formais-musicais da época da incorporação da música dos caipiras à indústria do disco impuseram-se muito mais por questões tecnológicas do que mercadológicas. A ressalva a ser feita fica por conta da recepção e da difusão, pois, a partir do momento em que aquela música passou a ser gravada, evidentemente, a maneira como o público a recebia e fruía foi, sem dúvida, radicalmente modificada $^{24}$. O que leva à conclusão de que, no caso da música caipira, a recepção e a difusão sofreram, de imediato, maiores transformações se comparadas à criação e produção.

Numa narrativa que, grosso modo, divide em três fases o período compreendido entre as gravações pioneiras de Cornélio Pires e o sucesso absoluto de mercado alcançado nos anos $1990^{25}$, autores como Camila Koshiba Gonçalves (2013), Eduardo Vicente (2014), Ivan Vilela (2015), José Ramos Tinhorão (2013), José Roberto Zan (2004), Lucas Antonio Araújo (2014), Martha Tupinambá de Ulhôa (1999), Rosa Nepomuceno (1999), Waldenyr Caldas (1979), têm discutido e escrito a história desta música (e de sua linguagem) a partir de prismas que privilegiam anunciar, nomear, classificar, debater e analisar as diferentes etapas pelas quais a música dos caipiras (e suas derivações) passou.

Em comum, há o entendimento de que ao longo do século XX - como parte e resposta ao desenvolvimento e consolidação da indústria fonográfica e de um mercado consumidor brasileiros, e da própria experiência histórica do país no período -, a música dos caipiras foi perdendo, paulatina e constantemente, muito das características constitutivas e essenciais que

\footnotetext{
${ }^{24}$ Sobre este assunto ver GONÇALVES, 2013.

25 Em termos comerciais, a "grande explosão" do gênero sertanejo viria a ocorrer somente "a partir da decadência do rock [nacional], por volta de 1987” (VICENTE, 2014, p. 107).
} 
trazia desde suas origens no seio da cultura caipira e que haviam sido consideravelmente mantidas pelas primeiras gravações e naquelas realizadas até o início da década de 1940.

Há também razoável consenso em compreender-se que a primeira fase vai de 1929 a meados da década de 1940, que há uma fase intermediária - de transição, adaptações, incorporações, mistura de matrizes musicais, criação de uma tradição - compreendida entre o pós-Segunda Guerra Mundial e o final dos anos 1960, e que a terceira fase inicia-se na virada para os anos 1970, alcançando seu auge na década de 1990 e tendo por característica uma ruptura quase total com os padrões e formas originais e definidores da musicalidade dos caipiras.

Há, então, uma primeira fase que traz por característica principal a autenticidade, uma manifestação de originalidade quase intocada", o fazer no disco tal e qual se fazia na roça. Edificado a partir das duplas pioneiras descobertas e lançadas por Cornélio Pires, este período é caracterizado pela presença quase unânime dos ritmos e gêneros caipiras e tem na moda de viola sua quinta-essência. Conforme escreveu Camila Koshiba Gonçalves, o ciclo dessas duplas caipiras pioneiras durou até a consolidação das rádios. Nesse período, segundo a autora, "a divulgação das duplas era feita basicamente através dos discos, Columbia e Victor, e teve como núcleo central os mesmos violeiros trazidos por Cornélio Pires" (GONÇALVES, 2013, p. 259). Tendo em vista que "a proliferação e diversificação das duplas caipiras se deu a partir de 1935-36" (GONÇALVES, 2013, p. 258), um novo ciclo dentro desta primeira fase teve início, em que "estas mesmas duplas [pioneiras] se dividiram pelos estúdios das gravadoras que atuavam no país, e permaneceram registrando modas de viola, cateretês e cururus. Tiveram, no entanto, que dividir espaço com as 'novas duplas', responsáveis pela criação de um novo formato que, além de caber nos três minutos dos $78 \mathrm{rpm}$, também alimentaram a programação radiofônica" (GONÇALVES, 2013, p. 259). Esse novo formato, posterior às primeiras gravações, já trazia algumas exigências das gravadoras, tais como certa "limpeza sonora ao tocar" e padrões de interpretação e instrumentação que fugiam àqueles típicos dos caipiras, e incluía, no hall dos "artistas caipiras", músicos e compositores de origem citadina $^{26}$ (VILELA, 2010, p. 99-100; TINHORÃO, 2013, p. 220-245).

\footnotetext{
26 "É preciso esclarecer que o interesse pelas "modas" caipiras ou sertanejas, nas primeiras décadas do século $\mathrm{XX}$, não estava restrito aos seus praticantes do interior, embora fosse essa a região da sua localização mais dinâmica. Mesmo compositores de vivência mais urbana também se dedicaram a esse tipo de repertório, entre eles o pianista Marcelo Tupinambá, nascido em Tietê, e o cantor paulistano Paraguaçu. [...] O próprio compositor Angelino de Oliveira (1888-1964) [...] revelava predominantemente um repertório típico da música popular urbana. Em especial, algumas de suas canções de sabor seresteiro (modinhas)" (IKEDA, 2004, p. 154).
} 
Em seguida veio uma fase, a segunda, em que foram incorporadas ao repertório e às formas da música gravada pelas duplas - por meio de modificações e fusões -, novas temáticas e matrizes musicais. Nesse período, que teve início a partir da segunda metade da década de 1940, consolidou-se durante as de 1950-60 e vigorou até a virada para os anos 1970, observou-se um "avanço [do] processo de desenraizamento e perda das características originais", onde a música paraguaia e depois a mexicana, "por influências da guarânia [...] e a introdução de temas românticos, dão início a 'um novo momento da relação entre música sertaneja e mercado" (VICENTE, 2014, p. 108). Em contrapartida a este desenraizamento, nesse período também se observa a inserção de outros ritmos (também considerados caipiras) ao repertório da música caipira gravada, "como o recortado, a querumana, [...] a polca paraguaia” e, em fins dos anos 1950, “o pagode caipira” (VILELA, 2010, p. 105), ritmo criado pelo violeiro Tião Carreiro que já nasce reconhecido como ritmo tradicional caipira (ARAÚJO, 2014, p. 253). Um outro fato interessante sobre esta fase é que as "duplas de música caipira", para além dos recém citados, gravavam gêneros como tango, bolero, valsa, baião - como comprovam as discografias de Tonico e Tinoco e Tião Carreiro e Pardinho, por exemplo -, sem que isto colocasse em xeque o reconhecimento dos mesmos (por parte de indústria, mercado e público) de que se tratavam de artistas genuinamente pertencentes ao gênero caipira.

Todos esses episódios pertencentes à segunda fase da história da música caipira devem ser considerados a partir da compreensão de que "ainda nos anos 50 começam a se delinear duas tendências distintas no interior do gênero, embora elas estejam longe de serem indissociáveis ou mesmo homogêneas" (ARAÚJO, 2014, p. 252). Assim, se por um lado "a música sertaneja, entre os anos 50 e 70, se abriu a inúmeras influências, tanto por parte de duplas identificadas com a tradição como por parte daquelas mais abertas às sonoridades estrangeiras", como componente deste processo e, talvez em resposta a ele, a partir de um determinado ponto surge um "movimento" em direção à manutenção, resgate ou mesmo (re)criação de uma tradição que, acreditava-se, corria riscos de se perder. Destarte,

nesta atmosfera de abertura, de diversificação estética, a música sertaneja também construiu, a partir de sua vertente tradicional, uma autoimagem, compartilhada por seu público, de detentora da tradição e das narrativas do passado, de agente da preservação da cultura rural nacional e capaz de narrar o passado rural, com suas "belezas naturais", ou suas lutas pela vida, 
além de instituir símbolos e ritmos como representantes desta tradição. (ARAÚJO, 2014, p. 255)

O que no excerto acima aparece como "música sertaneja em sua vertente tradicional" faz alusão à tradição que se instituiu a partir das primeiras duplas das Turmas Caipiras de Cornélio e da Victor. Parte indissociável do "guarda-chuva da música sertaneja", esta "vertente tradicional" tinha (e tem) na estética, nas formas, nas temáticas, nos símbolos e ritmos daquelas gravações e duplas pioneiras seus referenciais basilares ${ }^{27}$.

Já a noção de "duplas identificadas com a tradição" remete a uma gama de duplas surgidas nesta segunda fase que, mesmo se abrindo às novidades e inovações pelas quais passava a música sertaneja - ainda que em diferentes momentos de suas carreiras e em graus de intensidade e duração variantes -, mantiveram-se ligadas, de forma significativa, àqueles referenciais. De acordo com Lucas Antonio Araújo, "Tonico e Tinoco e Tião Carreiro e Pardinho foram determinantes, em épocas distintas, para a formação dessa tradição musical rural/nacional", constituindo-se, historicamente, como as "dupla[s] de maior sucesso e perenidade identificada[s] com a vertente tradicionalista" (ARAÚJO, 2014, p. 121 e 125).

No que diz respeito a seus símbolos e ritmos, paralelamente às duplas cantando em duetos de terças, a viola caipira e a moda de viola não só foram eleitos e instituídos como também continuaram sua trajetória enquanto representantes máximos da tradição na música dos caipiras. Como parte desta construção, ao auxílio da viola e daquelas duplas, confluíram alguns compositores e a figura da cantora e folclorista Inezita Barroso, chamada por Rosa Nepomuceno de "A Diva da Tradição" (NEPOMUCENO, 1999, p. 323). Sobre estes aspectos, assim escreveram Ivan Vilela, Jairo Severiano e a própria Rosa Nepomuceno:

durante todo o processo de legitimação da viola como um instrumento brasileiro, ela, de uma forma ou de outra, esteve ligada ao fazer do campo, mesmo quando era instrumento citadino nos séculos XVIII e XIX. Porém, nenhum momento legitimou e difundiu tanto a viola como as gravações de músicas dos caipiras, a partir de 1929. Esse evento esteve intimamente ligado à radiodifusão que não só fez que a viola se popularizasse em regiões

\footnotetext{
${ }^{27}$ Sobre este fato cabe a ressalva, porém, de que "a formação da vertente tradicional do gênero, embora sempre tendo como principal referência ritmos musicais tradicionais, nunca se fechou para a possibilidade de elaborar, desenvolver ou estilizar estes mesmos ritmos musicais, além de incorporar outros, como o caso da polca e mesmo do tango" (ARAÚJO, 2014, p. 121).
} 
onde seu alcance não se efetivara, como também fez que a realidade e aspectos da história desse camponês do Centro-Sudeste do país chegassem ao conhecimento de todos. (VILELA, 2010, p. 335)

Mesmo sofrendo forte influência paraguaia e mexicana, a música sertaneja brasileira entrou na segunda metade do século XX tendo ainda a velha moda de viola como gênero básico. Deveu-se a continuação dessa tradição, principalmente, à atuação de figuras como o violeiro Tião Carreiro, os compositores Teddy Vieira e Lourival dos Santos e a cantora Inezita Barroso. (SEVERIANO, 2008, p. 443)

Teddy Vieira, ao lado de Lourival dos Santos e Tião Carreiro são considerados como figuras que mantiveram viva a tradição da música caipira. (NEPOMUCENO, 1999, p. 148)

Quanto às suas particularidades, autoimagem e sentidos, esta vertente tradicional caracteriza-se "pela construção de imagens do Brasil e também por um discurso que se manifesta de maneiras distintas, marcadamente em paisagens rurais e com um variado leque de personagens que protagonizam narrativas que ora podem ser bucólicas, ora trágicas, ora épicas", tendo na tensão entre tradição e modernidade uma de suas características mais perenes (ARAÚJO, 2014, p. 204, 196, respectivamente). Somado a isso, define esta vertente - que tem no termo "música sertaneja de raiz" um sinônimo -, o fato de que

suas narrativas são dirigidas para um público sem educação formal, e com referências à realidade rural, bem como a certos valores que permeiam o discurso das letras, [criando] um universo narrativo cujos heróis serão homens comuns e tipos populares, também sem educação formal que estão dispostos a defender os valores característicos, que são a base das visões compartilhadas em seu repertório do gênero, contrapostos a uma latente desconfiança ao que é considerado novo, moderno e incerto. (ARAÚJO, 2014, p. 255)

Ou seja, resumidamente é possível concluir que, ancorada no referencial fonográfico produzido pelos pioneiros (em meio a um ambiente de abertura e diversificação estética), "adotando sonoridades identificadas com a ruralidade" e com a musicalidade da cultura caipira, essa "vertente tradicional" se constituiu a partir de um conjunto de valores e saberes - 
de um ethos - que a tornava, simultaneamente, elegível e legitimada não só "como detentora da tradição rural brasileira, [...] mas também [como] narradora da formação nacional a partir da ruralidade e do passado", caracterizando-se "justamente por essas pretensões de nacionalidade e construção de narrativas [...] acerca do Brasil rural, do passado e da formação nacional" (ARAÚJO, 2014, p. 252).

A partir de fins dos anos 1960 e início dos 1970, concomitante ao "período de consolidação da moderna indústria fonográfica brasileira” (DIAS, 2008, p. 22), é possível observar uma terceira fase do processo histórico da música caipira. Esta etapa será de “orientação do gênero a um mercado jovem e urbano" (VICENTE, 2014, p. 109), no momento exato em que, no país, se consolidavam "as estratégias de atuação, os referenciais a partir dos quais a produção musical se [orientaria] no seu processo de adaptação a um mercado de consumo crescente, urbano e moderno" (VICENTE, 2014, p.81). Em razão disso, também, que Eduardo Vicente afirma ser indiscutível "a importância que os anos 1960 e 1970 tiveram para a cristalização dos padrões de consumo e para a organização de toda a indústria fonográfica no país” (VICENTE, 2014, p. 82).

Neste cenário, "o esquematismo da produção na indústria cultural e sua subordinação ao planejamento econômico" ganhavam, cada vez mais, força e razão de ser, num encadeamento segundo o qual "a fabricação de mercadorias culturais idênticas" (DIAS, 2008, p. 31) tornar-se-ia cada vez mais a regra, até atingir seu ápice (para o gênero em questão) a partir da década de 1990, numa dinâmica em que, ao longo de mais ou menos trinta anos,

ao desenraizamento do gênero sertanejo acabava correspondendo também um desenraizamento dos próprios artistas, apresentando-se a música sertaneja para alguns deles prioritariamente como opção comercial. Essa padronização e orientação mercadológica do segmento irá permitir um alto grau de divisão e organização do trabalho de produção e promoção, bem como a sua crescente sofisticação. Neste contexto, um eficiente esquema de produtores e empresários é formado e os shows se tornam altamente profissionais e sofisticados. (VICENTE, 2014, p. 111)

Como reflexo e em decorrência desta conjuntura - que teve na dupla Leo Canhoto e Robertinho sua inicial e principal referência -, quase tudo o que havia de original-tradicional na música dos caipiras foi relegado e/ou perdido em prol de uma modernização e adequação a uma "nova" lógica de mercado e de organização industrial. Foi assim que, no repertório de 
Leo Canhoto e Robertinho, por exemplo, perderam-se

as imagens mais recorrentes do Brasil na música sertaneja vistas até então: a exaltação do passado e a narrativa trágica ou épica, que caracterizaram a música sertaneja que se propôs a narrar e definir o que seria a cultura e a formação nacional, com base no passado rural e na exaltação do homem comum. Não há também no repertório da dupla a costumeira tensão com a modernidade e urbanização e, menos ainda, a crítica a esta, assim como a recusa de uma "degradação de valores" tão denunciada na música sertaneja tradicional. (ARAÚJO, 2014, p. 251)

A ausência de crítica social nas letras, tão cara à vertente tradicional do gênero, também foi uma das características desta terceira fase (VICENTE, 2014, p. 109; ARAÚJO, 2014). Sem contar na substituição da viola caipira por guitarras elétricas e outros instrumentos ligados a culturas que não a caipira, o abandono da forma da moda de viola como padrão referencial, e a adoção de uma estética mais alinhada com a cultura estadunidense (que por vezes flertava com a dos filmes de bang bang italianos). Sobreviveria, apenas, o canto em duetos de terça.

Controvérsias e debates à parte, é fato que, desde sua entrada para o "mundo do disco", a música dos caipiras sofreu inúmeras influências, interferências, modificações, adaptações, apropriações, rupturas, ressignificações. Também é fato que sua historicidade não pode ser apreendida se considerada isoladamente, à parte do desenrolar do processo histórico inerente tanto ao mercado de música quanto aos da indústria fonográfica e dos meios de comunicação no Brasil do século XX.

Dessa forma, se o início de sua história na indústria do disco e no mercado da música é marcado por um baixo nível de pressão mercadológica-industrial - o que de alguma forma contribuiu para que "um certo grau de originalidade" fosse mantido -, sua crônica descreve, em diferentes fases, um caminho trilhado rumo às constatações de Marcia Tosta Dias, Eduardo Vicente e José Geraldo Vinci de Moraes, citadas há pouco. Qual sejam, as de um percurso em que determinada manifestação musical é incorporada/apropriada pela indústria fonográfica e pelo mercado da música, num processo que gera um desenraizamento cada vez mais profundo e notável, causando a perda de suas características, conteúdos e sentidos originais; processo este influenciado e por vezes determinado tanto pelas próprias adaptações e propósitos que determinadas formas de geração e criação dessas canções sofreram quanto 
pelo sensível aumento das solicitações e pressões mercadológicas às quais foram expostas e "obrigadas" a responder de modo cada vez mais intenso.

Nesse caminho, "muitas foram as variações e mudanças ocorridas" dentro da história de um fazer musical que se plasmou sob o signo de uma "heterogênea unidade" e que "ao longo do tempo buscou construir diversas autoimagens e ao mesmo tempo imagens da realidade em que se [inseria]" (ARAÚJO, 2014, p. 252).

Entre as décadas de 1930 e final da de 1960, essa música adquiriu "inserção nacional significativa e [passou] a ser mais abrangente"; almejando "ser nacional", buscou "a posição de representante da música rural brasileira" e de "narradora da formação nacional a partir da ruralidade e do passado" (ARAÚJO, 2014, p. 252).

Numa trajetória em que, já no início da década de 1930, as gravações caipiras eram ouvidas e reconhecidas como uma "marca registrada da musicalidade paulista" (GONÇALVES, 2013, p. 24), a partir da década de 1950 a música sertaneja abriria caminhos para se tornar "um dos gêneros mais populares do mercado fonográfico nacional" (ARAÚJO, 2014, p. 252).

Parte fulcral desse processo foi a criação e consolidação de uma "tradição" e de uma "vertente tradicional" que reivindicaram para si e se legitimaram enquanto detentoras, narradoras e perpetuadoras da cultura, história e tradição rural brasileira.

Considerando o recorte temporal que vai de 1929 a 1970, retomam-se aqui algumas questões relacionadas à integração da música dos caipiras à indústria fonográfica e de sua consequente trajetória na fonografia. Durante esse período de tempo, duas gravadoras nacionais, diga-se de passagem - tiveram papel fundamental para a gravação e difusão desta música: Continental e Chantecler.

Se a Columbia ${ }^{28}$, mesmo sob apriorística desconfiança ${ }^{29}$, foi a pioneira na gravação de música caipira no país, a Continental seria "de crucial importância para a produção de

\footnotetext{
28 "Em 1928, [...] a empresa paulista Byington \& Cia., dirigida por Alberto Jackson Byington Jr., firma contrato com a Columbia norte-americana para a prensagem e distribuição de seus discos no [Brasil]. Simultaneamente, a empresa inicia também a gravação de discos de música brasileira que, assim como o catálogo da Columbia, são lançados com o selo Columbia do Brasil. As primeiras gravações nacionais surgem já em 1929 [...]" (VICENTE, 2010, p. 79).

29 “A empresa de Byington, como se sabe, iria se tornar, a partir de sua relação com Cornélio Pires, a pioneira na gravação de música sertaneja no país. Ainda em 1928, Ariowaldo Pires, o Capitão Furtado, sobrinho de Cornélio, atua como seu tradutor numa conversa com o norte-americano Wallace Downey, diretor artístico da
} 
estilos e canções nacionais e regionais" (ARAÚJO, 2014, p. 120), ao passo que a Chantecler desempenharia "um papel fundamental para o desenvolvimento da música popular paulista, especialmente a música sertaneja” (VICENTE, 2010, p. 77).

A Continental foi criada em 1943, quando, ao final de seu contrato com a ColumbiaEUA, o empresário Alberto Jackson Byington Jr. decide fundar sua própria gravadora ${ }^{30}$. Em sua trajetória ${ }^{31}$, principalmente a partir dos anos 1960, a empresa vinculou-se "cada vez mais ao mercado regional e a gêneros musicais voltados a um público de menor poder aquisitivo (VICENTE, 2017, p. 329), especializando-se "em produzir e divulgar discos das tradicionais duplas de violeiros" (ARAÚJO, 2014, p. 120).

A exemplo da Continental, a Chantecler - nome derivado da expressão francesa chant clair - também "procurou atuar junto a um público de menor poder aquisitivo, vinculado de um modo geral ao consumo de gêneros musicais mais populares, como o da música sertaneja e regional" (VICENTE, 2017, p. 331). A diferença entre as duas gravadoras, nesse caso, é que a Chantecler assim se posicionou no mercado desde o início de suas atividades. Sobre isso, Eduardo Vicente observou que

um aspecto importante na estratégia da empresa para atuar em mercados marginais e de menor poder aquisitivo foi continuar distribuindo muitos de seus artistas através de discos de 78rpm num momento em que o LP já estava em vias de se tornar dominante no mercado. Com isso, assegurava sua presença junto a um público que tinha dificuldades para substituir seus antigos aparelhos reprodutores de discos. (VICENTE, 2010, p. 83)

Fundada em 1958 a partir de uma parceria com a $\mathrm{RCA}^{32}$, "a principal área de atuação da Chantecler foi mesmo a da música sertaneja”, figurando entre seus primeiros e principais

Columbia do Brasil. Na conversa, Cornélio propõe a gravação de músicas e anedotas de sua Turma Caipira. Downey apresenta Cornélio a Byington, que deve tomar a decisão final sobre o assunto. Byington recusa a proposta por considerar que não existiria no país um mercado para esse tipo de produção, mas os dois acabam chegando a um acordo em que a empresa se dispõe a gravar os discos desde que Cornélio assuma os custos de sua produção e prensagem. Os discos então saem pela gravadora com um selo de cor distinta do da Columbia e por uma série especial (a Série Cornélio Pires)" (VICENTE, 2010, p. 79).

${ }^{30}$ A Columbia, a partir de 1943, passou a ser representada, no Brasil, pela Odeon (VICENTE, 2010, p. 79).

${ }^{31}$ Sobre a trajetória da Continental, bem como de outras empresas do mesmo ramo, e para uma visão mais aprofundada da atuação e história da indústria fonográfica no Brasil e no mundo ver Márcia Tosta Dias, 2008 e Eduardo Vicente, 2014.

32 “Operando no Brasil desde 1930, a RCA contava, para a distribuição de seus produtos, com os serviços da Cássio Muniz S/A, uma empresa de vendas no atacado e varejo. Localizada na Praça da República, esquina com a Rua do Arouche, a Cássio Muniz contava com uma rede de representantes espalhada por todo o país. Por seu intermédio ela distribuía, além de toda a linha de discos e equipamentos eletrônicos da RCA-Victor (toca-discos, 
artistas contratados nomes como Tibagi e Miltinho, Tião Carreiro e Pardinho, Zico e Zeca, Pedro Bento e Zé da Estrada, Palmeira e Biá, Zé Bettio e Mário Zan (VICENTE, 2017, p. $333)$.

À baila de todo o processo de urbanização e modernização pelo qual o Brasil passou de forma crescente e constante, notadamente a partir da década de 1950, já no início dos anos 1960 começam a consolidar-se no país algumas transformações que iriam afetar diretamente e provocar uma expressiva reorganização do setor fonográfico ${ }^{33}$. Dentre as mais significativas, destacam-se a chegada da Philips, importante gravadora internacional, em 1960, e, ao longo daquele decênio, a "efetiva substituição do rádio pela TV como principal veículo de comunicação do país” (VICENTE, 2017, p. 333). Associados, esses acontecimentos acabaram por fomentar "um extraordinário crescimento do mercado fonográfico" brasileiro. Ao mesmo tempo, potencializaram uma "estratificação do consumo musical” e um processo de hierarquização dentro da música popular, seus artistas e públicoalvo.

Agudizando, dando maturidade e consagrando este fenômeno de consolidação da moderna indústria fonográfica brasileira (DIAS, 2008), a década de 1970 - período que ultrapassa o recorte temporal deste trabalho - verá "o surgimento de gravadoras enquanto braços fonográficos de emissoras de TV, sendo o exemplo mais importante o da Som Livre, criada pela Rede Globo em 1971" e dará boas vindas a duas importantes companhias internacionais, a Warner, em 1976 e Ariola, em 1979" (VICENTE, 2010, p. 81-82).

Em resposta a esse novo cenário, desse momento em diante "gravadoras tradicionais" como a Continental e a Chantecler confirmariam e aprofundariam suas opções e inserções mercadológicas numa marcha que as vincularia de maneira progressivamente tenaz e cada vez mais acentuada a seus mercados regionais e às classes de baixa renda, prospectando mercados que aos olhos das majors eram percebidos e avaliados como "mercados de menor interesse econômico" (VICENTE, 2010, p. 81-82). Diante disso, seu mercado consumidor, que havia sido composto desde o início de suas operações a partir de um estrato da população "bem mais vulnerável às flutuações da economia", assentou-se sobre estas bases de modo

rádios e televisores), aviões da Cessna, veículos da GM e todo um vasto catálogo de produtos (em sua maioria importados). Ao decidir criar, em 1956, a sua própria rede de distribuição no país, a RCA sugere a Cássio Muniz - como uma forma de compensação - que crie sua própria gravadora, valendo-se do know-how da empresa. O acordo era de que a Cássio Muniz mantivesse, ainda por dois anos, a distribuição de discos da RCA, para poder consolidar seu próprio investimento na área. Já no ano seguinte, a Chantecler abria mão da distribuição da RCA devido ao grande sucesso de suas próprias produções" (VICENTE, 2010, p. 82).

${ }^{33}$ Esta questão está muito bem desenvolvida no texto "Chantecler: uma nova gravadora popular paulista" (VICENTE, 2010). 
cada vez mais intenso e irreversível. Esta "baixa imunidade" a crises de seu público consumidor aliado ao fato de que os discos destas companhias possuíam preço final de venda inferior (se comparados aos das majors) refletiam-se, obviamente, na receita das empresas, que enfrentaram os anos 1970 sob déficits e crises fiscais. A solução, como no caso de inúmeras outras companhias no Brasil e no mercado internacional, muitas vezes vinha por meio de fusões e/ou incorporações ${ }^{34}$. Com catálogos, inserções de mercado, trajetórias e perfis muito próximos, a Continental, na década de 1970, acabou por absorver a Chantecler. (VICENTE, 2010, p. 82-84).

Antes que esse momento chegasse, no entanto, a Chantecler, ainda como empresa autônoma, já havia se consolidado no mercado fonográfico brasileiro como "a gravadora" da música sertaneja (NEPOMUCENO, 1999, p. 168), sendo responsável “por um trabalho fundamental de documentação da música popular brasileira, registrando os trabalhos de artistas populares, vinculados a segmentos regionais, num momento em que as grandes empresas do setor praticamente ignoravam a existência desse mercado" (VICENTE, 2010, p. 85). Em seu apogeu, contou com um cast reconhecidamente de peso, mantendo contratos com os maiores artistas do gênero, dentre os quais, Tonico e Tinoco e Tião Carreiro e Pardinho - duplas reconhecidas como as mais representativas da "vertente tradicional" -, e chegou a dispor de uma espécie de time de compositores, uma verdadeira "equipe da Chantecler para compor músicas para as principais duplas da gravadora" (ARAÚJO, 2014, p. 122). Como capitães deste time, podem ser citados os nomes de Lourival dos Santos, Moacir dos Santos e Teddy Vieira. Na discografia de Tião Carreiro e Pardinho, por exemplo, "a maior parte das canções tem entre seus compositores Lourival dos Santos e Moacir dos Santos, por vezes em parceria entre si ou com outros letristas" (ARAÚJO, 2014, p. 122) ) $^{35}$.

Quanto a Teddy Vieira, “além de [ser] um compositor responsável por diversos clássicos", como "O menino da porteira" - um dos maiores sucessos não somente de Tonico e Tinoco como, de forma atemporal, da música sertaneja -, é também o autor de substantiva porcentagem do repertório de Tião Carreiro e Pardinho (ARAÚJO, 2014, p. 122). Como se verá a seguir, o compositor "era também um empresário, responsável por descobrir e promover novas duplas" (ARAÚJO, 2014, p. 123).

\footnotetext{
${ }^{34}$ Sobre o assunto ver DIAS, 2008 e VICENTE, 2010.

${ }^{35}$ Tião Carreiro, além de cantor e virtuose da viola caipira, foi também autor de muitas canções do repertório da dupla que formou com Pardinho.
} 


\subsection{Teddy Vieira}

Nascido em 23 de dezembro de 1922, na cidade de Itapetininga, interior do Estado de São Paulo, Teddy Vieira de Azevedo foi um importante compositor e empresário. Itapetingano de nascimento, tinha em Buri - município $89 \mathrm{~km}$ distante de sua cidade natal seu lugar de predileção: era para lá que ia sempre que podia, "para descansar e fazer suas caçadas e pescarias" ${ }^{\prime 36}$. E, segundo informa Sandra Cristina Peripato ${ }^{37}$, foi justamente em uma dessas viagens a Buri, em 16 de dezembro de 1965, às vésperas de completar 44 anos, que o compositor-empresário faleceu, vítima de um acidente automobilístico na Rodovia Raposo Tavares.

As atividades profissionais de Teddy Vieira concentraram-se, peremptoriamente, dentro do gênero musical que se convencionou chamar de música sertaneja. Seus dados artístico-biográficos $^{38}$ apontam que sua primeira composição foi escrita quando ele tinha 18 anos. Assim, infere-se que seu período produtivo está compreendido entre os anos de 194041 e 1965. Nesses vinte e cinco anos de atividade como compositor de canções, Teddy Vieira teve autoria atribuída a quase trezentas músicas, a esmagadora maioria delas em parceria com uma ou mais pessoas, grande parte gravada pelos mais reconhecidos nomes da música sertaneja.

De acordo com Rosa Nepomuceno, o compositor "assinou mais de uma centena de toadas e modas de viola" (NEPOMUCENO, 1999, p. 148). "Fazedor de sucessos" (NEPOMUCENO, 1999, p. 149), Teddy Vieira, no entanto, não se limitou a escrever canções baseadas apenas nos gêneros mais tradicionais da música caipira. A já citada jornalista Sandra Cristina Peripato, responsável pelo portal "Recanto Caipira"39 - um importante site sobre a "música sertaneja" -, apresenta uma lista contendo duzentas e oitenta e cinco (285) composições às quais a autoria (singular ou em parceria) é atribuída a Teddy Vieira ${ }^{40}$. Já o "Instituto Memória Musical Brasileira (IMMuB)" 41 tem catalogado novecentos e vinte e sete (927) fonogramas registrando composições do itapetingano, além de cinco versões também a

\footnotetext{
${ }^{36}$ https://www.recantocaipira.com.br/duplas/teddy_vieira/teddy_vieira.html (acesso em 05/05/2019).

${ }^{37}$ https://www.recantocaipira.com.br/duplas/teddy vieira/teddy vieira.html (acesso em 05/05/2019).

${ }^{38}$ Fonte: Dicionário Cravo Albin da Música Popular Brasileira, http://dicionariompb.com.br/teddy-vieira/dadosartisticos (acesso em 20/04/2019).

${ }^{39}$ https://www.recantocaipira.com.br/

40 Disponível em: https://www.recantocaipira.com.br/duplas/teddy_vieira/teddy_vieira.html (acesso em 20/04/2019).

${ }^{41}$ https://immub.org/ (acesso em 20/04/2019).
} 
ele creditadas $^{42}$. O escrutínio dessas fontes, por meio principalmente da audição dos fonogramas ${ }^{43}$, aponta, a priori, que a atividade de Vieira como compositor extrapolou os limites do gênero sertanejo. Conforme ilustra o quadro abaixo, no repertório de composições de Teddy Vieira que foram gravadas constam tangos, boleros, baiões, valsas, canções românticas (brega).

\begin{tabular}{|c|c|c|}
\hline Título & Gênero & Intérprete \\
\hline "Ainda te quero"44 & bolero & Waldick Soriano \\
\hline "Alvorada no sertão"45 & baião à la Luiz Gonzaga & Waldick Soriano \\
\hline "Copo da Amargura"46 & tango & Waldick Soriano \\
\hline "Quinze Primaveras"47 & valsa & Giane \\
\hline "Maldita Hora"48 & tango & José Lopes \\
\hline
\end{tabular}

No mesmo sentido, chama a atenção o fato de que suas músicas foram gravadas, também, por artistas que não construíram suas carreiras direta ou necessariamente ligados ao gênero sertanejo, casos de José Augusto, Alberto Calçada, Haroldo José, e dos já mencionados Waldik Soriano e Giane. São exemplos as gravações de "Cantando Pra Não

42 1) "Maldita Lembrança" (Maldito Recuerdo) (Ramon Inclan/Vrs. Teddy Vieira). Disco 78 RPM, gravadora: Sertanejo, catálogo: PTJ-10.075-a , 1960, artistas: Sulino e Marrueiro; 2) "Moreninha Brasileira" (Morenita Lugareña) (Melg Chase/Vrs. Palmeira/Teddy Vieira. Disco 78 RPM, gravadora:RCA-Victor, catálogo: 801316-a, 1954, artistas: Palmeira e Biá; 3) "Penas de Minh'Alma" (Penas Del Alma) (Felipe Valdés Leal/Vrs. Teddy Vieira/N. Gomes). LP: NENETE E DORINHO, gravadora: RCA Victor, catálogo: BBL 1048, 1959, artistas: Nenete e Dorinho; 4) Rola "Mensageira" (Paloma Blanca) (Neneco Norton/Vrs. Teddy Vieira). Disco 78 RPM, gravadora: Chantecler, catálogo: 78-0178-a, 1959, artistas: Irmãs Galvão /Élcio Alvarez; 5) "Olhos Negros “(Otchi Chiornia) (Tradicional/Adpt. Teddy Vieira). Disco 78 RPM, gravadora: Chantecler, catálogo: 78-0175-a, 1959, artistas: José Lopes/Sid Biá.

${ }^{43}$ Disponíveis no já citado site do Instituto Memória Musical Brasileira e também no Youtube (acessos ao longo da pesquisa).

44 “Ainda Te Quero" (Waldick Soriano/Teddy Vieira). LP/CD: WALDIK SORIANO, gravadora: Chantecler , catálogo: CMG 2163, 1962, disponível em https://immub.org/album/waldik-soriano (acesso em 10/05/2019).

45 “Alvorada no sertão (Waldik Soriano/Teddy Vieira). LP/CD: WALDIK SEMPRE WALDIK, gravadora: Copacabana, catálogo: CLP 11506, 1967, disponível em https://immub.org/album/waldik-sempre-waldik (acesso em 10/05/2019).

46 "Copo da Amargura” (Waldick Soriano e Teddy Vieira). LP: QUEM ÉS TU?, gravadora: Chantecler , catálogo: CMG 2108, 1961, disponível em https://immub.org/album/quem-es-tu (acesso em 10/05/2019).

47 “Quinze Primaveras” (Alberto Calçada/Pierre/Teddy Vieira) CPS (compacto simples), gravadora: Chantecler, catálogo: C-33.6162, s/d, disponível em: https:/www.youtube.com/watch?v=11nadXv-vGM (acesso em 10/05/2019).

48 "Maldita Hora (Teddy Vieira/Waldick Soriano)". LP: CALENDÁRIO DO AMOR, gravadora: Chantecler, catálogo: CMG 2347, 1965, disponível em https://www.youtube.com/watch?v=9G i3K3WTV0 (acesso em 10/05/2019). 
Chorar", com José Augusto ${ }^{49}$, "Baião Número Cinco (baião No 5)", por Aberto Calçada ${ }^{50}$ e “Taça da Ilusão", na voz de Haroldo José ${ }^{51}$.

Esse trânsito entre diferentes gêneros e ritmos, bem como essa presença plural de artistas na fonografia que registra as obras de Vieira não causa estranheza. Conforme discutido anteriormente, alguns dos gêneros e ritmos, citados há pouco, foram incorporados ao grande guarda-chuva de gêneros e ritmos que compunham a "heterogênia unidade" da música sertaneja, muitos deles passando a ser "identificados como gêneros pertencentes ao conjunto da música sertaneja" ou mesmo associados "à tradição" (ARAÚJO, 2014, p. 204) . $^{52}$.

Em relação aos dados apresentados tanto por Peripato quanto pelo Instituto Memória Musical Brasileira, abre-se aqui um parêntese pois, é preciso ponderar que, no Brasil, principalmente entre as décadas de 1930 e 1950 - período de afirmação e consolidação da profissionalização e especialização de músicos, compositores, arranjadores, produtores e diversos outros métiers ligados ao mercado da música e principalmente à indústria fonográfica (SANDRONI, 2001; DIAS, 2008; GONÇALVES, 2013) - era prática corrente atribuir-se a co-autoria de uma canção a alguém em troca de um "favor", de uma “colocação", de uma "chance para ser gravado" e/ou ter sua composição transmitida pelas ondas do rádio. Ao que tudo indica, esse modus operandi não se restringia a um setor específico do mercado e pôde ser observado entre compositores de diferentes gêneros musicais, tendo no samba um grande exemplo, como demonstra a literatura sobre o assunto e dramatiza o filme "Rio, Zona Norte", de Nelson Pereira dos Santos.

Por que haveria de ser diferente no meio sertanejo? Assim como sucedia nos demais gêneros de música popular que eram gravados pela indústria brasileira do disco, é razoável considerar que, no meio artístico e fonográfico pelo qual transitou Teddy Vieira, as parcerias, e mesmo as autorias, nem sempre correspondessem necessariamente ao "autor de fato" da obra em questão. Dessa forma, se essa observação for válida, é plausível questionar que o

\footnotetext{
49 "Cantando pra não chorar" (Élcio Álvarez/Teddy Vieira). LP: UM NOVO ÍDOLO, gravadora: Chantecler, catálogo: CMG 2241, 1963, fonte: https://immub.org/album/um-novo-idolo (acesso em 10/05/2019).

50 “Baião Número Cinco" (baião N ${ }^{\circ}$ ) (Teddy Vieira/Diogo Mulero "Palmeira"), Disco 78 RPM, gravadora: RCA Victor, catálogo: 80-1581-a, 1956, fonte: https://immub.org/album/78-rpm-61706 (acesso em 10/05/2019).

51 “Taça da Ilusão" (Nizio/Teddy Vieira). LP: TANGO TRISTE, gravadora: Chantecler, catálogo: CMG 2093, 1961, https://immub.org/album/tango-triste, https://www.youtube.com/watch?v=NMG3Si3ToN0 (acessos em 10/05/2019).

${ }^{52} \mathrm{O}$ mesmo fato será observado, em diferentes épocas, na discografia e repertório de Tião Carreiro e Pardinho, como ver-se-á adiante.
} 
número de composições de Teddy Vieira não coincida, talvez, com a quantidade de canções que ele efetivamente escreveu ou que a ele foram atribuídas.

Para além disso, e no que diz respeito mais diretamente ao número de fonogramas gravados com composições de Vieira, é preciso indicar que há casos onde uma mesma canção aparece com nomes diferentes. São exemplos "A enxada e a Caneta", que também aparece como "A caneta e a enxada", e, menos evidente, na moda de viola "O tenente mineirinho", que também aparece como "O ladrão de estrada", em registro de 1963 da dupla Craveiro e Cravinho 53 ; "Mulher sem nome" também aparece como "Punhal da Falsidade", tango que foi gravado, inclusive, por Guerra Peixe, no LP "Tangos de Sucesso - Guerra Peixe e Sua Orquestra" ${ }^{\circ 4}$.

Se o caso das relações entre autor-obra denuncia uma prática que pode ser seguramente apontada como corrente em determinado ponto do processo histórico da música popular brasileira e de sua indústria e mercado no Brasil, a segunda observação aponta e reflete a situação de uma indústria fonográfica e de um mercado de música que, à época ainda incipientes, em estágio de formação e de desenvolvimento, produziam e disponibilizavam produtos que chegavam ao mercado trazendo nenhuma ou - quando muito - poucas informações sobre os profissionais envolvidos em seu processo artístico, industrial e comercial. De mais a mais, a falta de cuidado e acuidade em relação às parcas informações quando existentes - inseridas nos discos (créditos aos compositores, ficha técnica de músicos executantes, arranjadores, datas e locais de gravação, etc) dificultam não só uma avaliação mais precisa dessa questão das autorias e parcerias como de toda uma gama de outras.

Parêntese feito - e a despeito dessa limitação que de maneira geral inibe uma postura mais afirmativa e/ou conclusiva sob certos aspectos e dificulta o esclarecimento de determinados pontos em diferentes pesquisas sobre os temas a ela inerentes -, este trabalho aceita que são de Teddy Vieira as composições a ele atribuídas.

A análise do repertório de composições do itapetingano aponta que em sua obra, ao tratar de temas universais - como a luta pela sobrevivência, o amor, a morte, a saudade, a traição, a injustiça, a desilusão, os conflitos interpessoais, o humor - o autor busca construir uma imagem do homem e de suas relações, de sua cultura e experiência, que coadune com os parâmetros essenciais da cultura e música caipiras. Desse modo, as narrativas das letras, na

\footnotetext{
53 https://immub.org/album/78-rpm-64147 e https://immub.org/album/os-reis-do-pagode-tiao-carreiro-epardinho (acesso em 22/04/2018).

${ }^{54}$ Gravadora: Chantecler, Catálogo: CMG 2090, Ano: 1961, Artistas: Guerra Peixe https://immub.org/album/tangos-de-sucesso-guerra-peixe-e-sua-orquestra , (acesso em 22/04/2018).
} 
maioria dos casos, referem-se ao e refletem o "mundo caipira", autoreferenciando e enaltecendo seus valores e características essenciais e/ou confrontando-os com os de outras culturas/realidades. Fazendo minhas as palavras de Lucas Antonio Araújo ${ }^{55}$, resumidamente, é plausível assumir que as músicas compostas por Teddy Vieira trazem "as imagens do Brasil presentes e recorrentes no repertório da música sertaneja, partindo da ruralidade, do passado e de uma valorização da tradição e oposição em relação aos valores considerados modernos" (ARAÚJO, 2014, p. 239). Tudo isso alcançado seja por meio de "imagens idílicas de exaltação da natureza e da terra e do homem em harmonia com este ambiente, seja [pela] descrição de um passado épico, em que o homem rural é descrito como um herói portador de grande coragem pessoal e capaz de tudo para defender sua honra" (ARAÚJO, 2014, p. 254). Ainda sobre o repertório escrito por Teddy Vieira, Rosa Nepoumuceno observa que o compositor "apreciava temas sociais, contando verdadeiras epopeias protagonizadas por ricos prepotentes em confronto com gente humilde", sendo o gênero moda de viola aquele que mais aborda essa temática a partir deste ponto de vista (NEPOMUCENO, 1999, p. 148).

Com relação aos gêneros musicais representados pelo conjunto da obra de Viera, a partir das composições que se pôde ter acesso via audição de fonogramas ${ }^{56}$, constata-se que há, de fato, uma pluralidade de gêneros que serviram de matéria-prima para o compositor. Em fonogramas foram registrados tangos, boleros, valsas, modas de viola, cururus, pagodes de viola, enfim, praticamente todos os gêneros tratados em item anterior e que, como demonstrado, associam-se ou foram integrados ao guarda-chuva de gêneros caipiras.

Como empresário e "caça-talentos" Teddy Vieira foi "responsável por descobrir e promover novas duplas" (ARAÚJO, 2014, p. 123), colaborando decisivamente para o surgimento de muitos artistas sertanejos como Leôncio e Leonel, Zico e Zéca, Liu e Léu, Vieira e Vieirinha, Sulino e Marrueiro, Mineiro e Manduzinho, Zilo e Zalo, Waldomiro e Waldemar, Tião Carreiro e Pardinho. Ajudou também muitos compositores, como Lourival dos Santos, Carreirinho, Luiz de Castro, Benedito Seviero, Sebastião Víctor, Roque José de Almeida e Nelson Gomes, “encaixando" suas músicas em repertórios e gravações.

Teve atuação constante e desempenhou importante papel dentro da indústria fonográfica brasileira, sendo em boa medida responsável por dar as cores e contornos a um gênero musical que, justamente durante as décadas de atuação profissional de Vieira, foi estilizado, criou, definiu e alterou seus padrões estéticos e comerciais. No ano de 1956 passou

\footnotetext{
${ }^{55}$ Adapto o trecho de Araújo a meus propósitos.

${ }^{56}$ Fontes: https://immub.org, www.youtube.com, www.spotify.com (acessos ao longo da pesquisa).
} 
a ser diretor do setor sertanejo da Columbia e em 1958 "transferiu-se para a Chantecler como diretor artístico" ${ }^{57}$. Em um período em que os diretores artísticos das gravadoras ainda cumpriam um notável papel de mediadores de relações entre a empresa fonográfica, o mercado, os artistas e o público, Teddy Vieira construiu sua reputação e carreira, vindo a se tornar uma referência para o show bizz sertanejo.

\footnotetext{
${ }^{57}$ Fontes: http://dicionariompb.com.br/teddy-vieira (acesso em 22/04/2019) e NEPOMUCENO, 1999, p. 149.
} 


\subsection{Teddy Vieira, Tião Carreiro (José Dias Nunes), Pardinho (Antônio Henrique de Lima): encontro para o sucesso.}

As relações de Teddy Vieira com a dupla Tião Carreiro e Pardinho iniciaram-se antes mesmo da dupla existir: teria sido o compositor-empresário que, não só formara a dupla, como também cunhara o pseudônimo "Tião Carreiro" 58 . De acordo com o que escreveu Lucas Antonio Araújo, "há relatos de que [Teddy Vieira] teria descoberto Tião Carreiro em um circo, formado e batizado a dupla dele com Pardinho” (ARAÚJO, 2014, p. 123).

À época trabalhando na Columbia, após formar e batizar a dupla, Vieira foi responsável pela gravação, em 1956, do primeiro disco desta, um $78 \mathrm{rpm}$ lançado sob o registro CB-10.302 que apresentava a gravação de duas composições de Teddy Vieira (em parceira): lado a - "Boiadeiro Punho de Aço" - moda de viola (Teddy Vieira e Pereira); lado b - "Cavaleiros do Bom Jesus" - cururu (Teddy Vieira e João Alves Mariano) ${ }^{59}$.

Iniciava-se ali um caminhar lado a lado que faria de Teddy Vieira, paralelamente a Lourival dos Santos, um dos compositores que mais criou letras para o repertório de Tião Carreiro e Pardinho (ARAÚJO, 2014 p. 167). Juntos, Lourival dos Santos e Teddy Vieira comporiam a canção "Pagode em Brasília", música que ficou consagrada na interpretação de Tião Carreiro e Pardinho e lançou o ritmo "pagode de viola", criado por Tião Carreiro e que foi imediatamente incorporado à tradição da música caipira como "ritmo original caipira", conforme mencionado anteriormente.

Neste percurso,

foi justamente nas vozes da dupla Tião Carreiro e Pardinho que Teddy Vieira conheceu alguns de seus maiores sucessos, como o "Rei do gado", "Nove e nove", em parceria com Lourival dos Santos e Tião Carreiro, "O mineiro e o italiano", com Nelson Gomes, "Porta fechada", com Moacyr dos Santos e outras. (http://dicionariompb.com.br/teddy-vieira - acesso em 26/04/2019)

De acordo com Rosa Nepomuceno, Tião Carreiro "foi o principal intérprete de Teddy Vieira” (NEPOMUCENO, 1999, p. 149). José Dias Nunes, seu nome de batismo, "foi um

\footnotetext{
${ }^{58}$ Antes de seu encontro com Teddy Vieira, José Dias apresentava-se e já havia gravado sob diferentes nomes artísticos (fonte: http://tiaocarreiro.com.br/discografia - acesso em 25/04/2019).

${ }^{59}$ http://tiaocarreiro.com.br/discografia-tiao/tiao-carreiro-e-pardinho-10/ (acesso em 25/04/2019).
} 
dentre vários violeiros que chegaram [à] cidade de São Paulo e se inseriram no mercado fonográfico após deixarem zonas rurais das quais eram originários” (AMARAL, 2016, p. 145).

Nascido no dia 13 de dezembro de 1934, em Catuti, então distrito rural de Montes Claros, região Norte do Estado de Minas Gerais, o violeiro foi criado desde a infância no interior de São Paulo, na região de Araçatuba. Trabalhando como agricultor desde muito cedo, "aos dez anos de idade [...] migrou para o interior do estado de São Paulo juntamente com sua família de lavradores em busca de melhores condições de vida" e, "após trabalhar na roça em municípios paulistas como Paulópolis, Flórida Paulista e Valparaíso, no final dos anos quarenta e início dos cinquenta, [...] formou suas primeiras duplas" (AMARAL, 2016, p. 146).

Morando durante a infância, adolescência e primeiros anos de sua vida adulta em regiões em que uma "grande diversidade de manifestações populares e matrizes caipiras" (AMARAL, 2016, p. 146) pautavam, conotavam e denotavam a vida social e cultural de seus habitantes, José Dias Nunes “construiu-se" como ser humano exatamente a partir dos valores e visões de mundo dessa cultura, algo que transpareceria em sua arte, maneira de falar, vocabulário, enfim, em seus modos de ser, ver e se relacionar com o mundo à sua volta.

Desde sempre convivendo com e absorvendo aquilo que havia de mais essencial à cultura caipira, foi provavelmente no

contexto dos circos, rádios e palcos das festas interioranas [...] que o violeiro começou sua formação musical na viola. Formado por diversas duplas e violeiros das zonas rurais onde provavelmente ainda ocorriam algumas manifestações e festas caipiras, este meio musical serviu de matrizes e referências para seus toques de viola. Essas influências e matrizes musicais caipiras podem ser facilmente identificadas em LPs como Sertão em Festa (1970) e Modas de viola classe A (1974), no qual o violeiro acompanha os sapateados de danças como a catira e o recortado. (AMARAL, 2016, p. 147)

E assim, a partir daquilo que fez destas matrizes e referenciais, Tião Carreiro se tornaria “o maior tocador de viola música sertaneja” (NEPOMUCENO, 1999, p. 149), representando e dando uma importância para o instrumento e para a moda de viola análoga à que Waldir Azevedo e Jacob do Bandolim deram ao choro, ao cavaquinho e ao bandolim, respectivamente. (NEPOMUCENO, 1999, p. 345). 
Acumulando, balanceando e contemporizando tradição com inovação, já na década de 1960 Tião Carreiro "era considerado o maior violeiro surgido na música sertaneja" (NEPOMUCENO, 1999, p.172; PINTO, 2008 e AMARAL, 2016). E, com o passar das décadas, foi confirmando sua posição de instrumentista referência, de reserva-âncora do legado da cultura e da música dos caipiras, de hábil equilibrista capaz de balancear inovação com tradição de maneira única e coerente, sendo até hoje reconhecido como tal entre pares, pelo público e pelo mercado da música. Conforme escreveu João Paulo Amaral,

\begin{abstract}
no contexto da música sertaneja romântica massificada pós anos noventa, a predominância de elementos e matrizes caipiras em sua discografia fez com que Tião Carreiro definitivamente fosse reconhecido no mercado fonográfico como um artista do segmento sertanejo de raiz, mesmo que seus últimos discos incluíssem algumas inovações estilísticas. Seus LPs passaram, portanto, a ser identificados como reservas de matrizes caipiras, mesmo que já transformadas, para as novas gerações de violeiros e músicos que até os dias atuais redescobrem suas gravações.
\end{abstract}

(AMARAL, 2016, p. 163)

Morreu relativamente cedo, aos 59 anos, em decorrência de complicações da diabetes e de doenças renais, deixando um expressivo legado e uma substancial discografia ${ }^{60}$.

Em 1954, na cidade de Pirajuí, interior do Estado de São Paulo, José Dias Nunes conheceu Antônio Henrique de Lima. O encontro, que ocorreu no circo Rapa Rapa, daria ensejo para a formação da dupla Zé Mineiro e Pardinho e, mais que isso, colocaria em contato duas figuras que, com personalidades diametralmente opostas (NEPOMUCENO, 1999, p. 338), seriam, um para o outro, o principal parceiro de carreira (PINTO, 2008, p. 35).

Nascido em São Carlos-SP, a 14 de Agosto de 1932, e falecido em Sorocaba, no dia primeiro de junho de 2001, Antônio era ajudante braçal e cantava nas horas de folga ${ }^{61}$. Além de cantar, tocava violão. Tinha um temperamento reservado, o que causava a maioria dos dissabores, brigas e separações com o boêmio e irrecuperável festeiro José (NEPOMUCENO, 1999, p. 338). Conforme apontou Rosa Nepomuceno, "fora do palco ou do estúdio [Pardinho] preferia guardar o instrumento e ir para o hotel ou para casa", ao contrário de seu parceiro

\footnotetext{
${ }^{60}$ Para mais dados biográficos e curiosidades sobre a vida e carreira de José Dias Nunes ver NEPOMUCENO, 1999, principalmente p. 337 a 348; PINTO, 2008 e AMARAL, 2016; e o site oficial de Tião Carreiro, principalmente neste link: http://tiaocarreiro.com.br/biografia/ .

${ }^{61}$ Fonte: http://tiaocarreiro.com.br/biografia/ (acesso em 03/05/2019).
} 
que "gostava de ambientes informais e alegres, onde pudesse tocar sem hora para parar, [puxando] a viola [...] para tocar em qualquer canto que lhe aprouvesse" (NEPOMUCENO, 1999, p. 338). A imprevisibilidade do parceiro também irritava a personalidade aparentemente mais metódica e calculista de Pardinho. Conforme o produtor Baccarin relatou a Nepomuceno, "muitas vezes Pardinho entrava no estúdio sem saber o que ia gravar, pois o Tião só decidia na hora. Tudo isso irritava [Pardinho]" (NEPOMUCENO, 1999, p. 338).

Em dupla com Tião Carreiro, Pardinho

tocava violão acompanhando os solos do violeiro e fazia a voz mais aguda no dueto, chamada pelos violeiros de primeira voz, apesar de ser, nesse caso, a segunda voz grave de Tião a que predominava como principal, sendo este um dos diferenciais importantes dessa dupla [...]. (PINTO, 2008, nota de rodapé $n^{\circ} 53$, p 35)

À época do encontro de José com Antônio, tanto para um quanto para o outro, a dupla Zé Carreiro e Carreirinho - que estava em evidência naquele ano de 1954 - era uma referência. Ainda se apresentando como Zé Mineiro e Pardinho, pouco tempo depois, em 1956, os fãs José e Antônio seriam convidados por seu ídolo, Carreirinho, a mudarem-se para São Paulo.

Era maio de 1956 e não demoraria para que Teddy Vieira cruzasse o caminho da dupla recém chegada à Capital do Estado. Já em novembro do mesmo ano em que se transferiram para a capital, a dupla, rebatizada e sob o apadrinhamento do empresáriocompositor, gravava seu primeiro disco, dando início a um percurso que num eterno fazdesfaz-refaz-desfaz os fez tão famosos (ou mais) e definitivos para a música sertaneja principalmente em sua vertente tradicional - quanto Tonico e Tinoco. 


\subsection{Tião Carreiro e Pardinho}

Entre idas e vindas, a dupla Tião Carreiro e Pardinho atuou e gravou, aproximadamente, por quatro décadas ${ }^{62}$. Estes quase quarenta anos são marcados por uma relevante presença não só nos palcos ${ }^{63}, \operatorname{rádios}^{64}, \mathrm{TVs}^{65}$ como também no mercado fonográfico brasileiro, uma vez que a dupla é reconhecidamente, dentro do segmento da música sertaneja tradicional, uma das que alcançaram maior sucesso de público e de vendas ao longo do período em que esteve ativa - e mesmo depois da morte de seus membros (ARAÚJO, 2014). Sobre o alcance de público, sua manutenção e renovação, Lucas Antonio Araújo chama a atenção para o seguinte fato:

visto que formou com Pardinho uma das duplas mais populares do gênero tradicional e a mais popular dentre elas no que diz respeito a um público mais jovem, podemos observar que cumprem também um papel de mediação entre gerações de público e artistas da música sertaneja. Têm popularidade mesmo entre o público da "moderna música sertaneja" até os dias atuais. (ARAÚJO, 2014, p. 123)

Este sucesso de vendas e público teve início no alvorecer da década de 1960. Tendo gravado dois discos de $78 \mathrm{rpm}$ pela Columbia, nos anos de 1956 e $1957^{66}$, a dupla se separou - pela primeira vez, das muitas... -, voltando a gravar juntos já pela Chantecler, em 1960. De maio de 1960 a novembro de 1961 gravaram sete discos de $78 \mathrm{rpm}$, os quais foram reunidos em forma de coletânea no primeiro LP da dupla, Rei do Gado, lançado no final do ano de 1961. No repertório deste long play de estreia foram incluídas as músicas "Teus Beijos" (Waldir Alves e Tião Carreiro), "Maria Ciumenta" (Bolinha e Tião Carreiro) e "Rei do Gado" (Teddy Vieira), que não constavam em nenhum dos $78 \mathrm{rpm}$ gravados pela dupla até

\footnotetext{
${ }^{62}$ Uma lista da discografia completa, com imagens das capas dos LPs e/ou CDs, de Tião Carreiro e Pardinho pode ser consultada em www.tiaocarreiro.com.br (acesso em 18/04/2019).

63 "No início dos anos setenta, a dupla Tião Carreiro e Pardinho já atraía plateias numerosas em apresentações, chegando no ano de 1972 a receber 'sete, oito mil pessoas em estádios, cinemas e circos, altíssimos números para a época"” (AMARAL, 2016, p. 15; NEPOMUCENO, 1999, p. 344).

64 “Após alguns anos não muito expressivos na Rádio Tupi, a partir do início dos anos sessenta, a dupla Tião Carreiro e Pardinho começa a firmar sua participação na Rádio Nacional de São Paulo (Rádio Globo atualmente), experiência que duraria mais de oito anos em programas como o de Edgar de Souza e, posteriormente, de Oscar Martins e Carlos Alberto" (AMARAL, 2016, p. 150).

${ }^{65}$ NEPOMUCENO, 1999.

${ }^{66}$ Discos: COLUMBIA CB-10.302 (11/1956) e COLUMBIA CB-10.356 (07/1957).
} 
então, e suprimidas as composições "A Casa Branca da Serra" (Tião Carreiro) e "Falsidade" (Tião Carreiro e Sebastião Victor), que aparecem nos discos 78 rpm CHANTECLER - PTJ10.113 (08/1960) e PTJ-10.149 (12/1960), respectivamente. Por fim, a canção "Urutu Cruzeiro" (Carreirinho e Paulo Calandro), que integra o disco $78 \mathrm{rpm}$ gravado em 1957, também foi incluída no repertório de "Rei do Gado" 67 .

Conquanto a Chantecler tenha apostado no formato $78 \mathrm{rpm}$ como carro chefe de suas vendas mesmo quando este formato já dava sinais de seu ocaso - conforme discutido anteriormente -, "é necessário destacar [...] que Tião Carreiro e Pardinho estão intimamente ligados ao advento do Long Play" (ARAÚJO, 2014, p. 133). Embora entre 1960 e, pelo menos até o final de 1964, os cantores tenham continuado a registrar e lançar fonogramas no padrão de $78 \mathrm{rpm}$, foi por meio do formato do long play "que a dupla se tornaria um grande sucesso comercial" (ARAÚJO, 2014, p. 133). E a prática de produzir LPs a partir da compilação e/ou inclusão de gravações lançadas anteriormente (ou mesmo concomitantemente) em discos de $78 \mathrm{rpm}$ seria uma realidade na carreira dos dois até pelo menos a metade de 1964. Construindo toda sua discografia dentro da Chantecler (depois Continental), Tião Carreiro e Pardinho, além dos 15 discos 78 rpm lançados entre 1960 e 1964 - que tiveram seus fonogramas em grande parte incluídos nos LPs lançados neste período -, produziram 49 LPs que foram disponibilizados no mercado, compondo um repertório que ultrapassa o número de 500 músicas gravadas.

Ao analisar essa discografia, João Paulo Amaral observou que

os discos da dupla vão sempre contemplar tanto gêneros de massa ligados à indústria fonográfica (tangos, milongas, rancheiras, guarânias, rasqueados, polcas paraguaias, sambas, toadas, baladas etc.) quanto gêneros mais caipiras (modas de viola, cururus, cateretês, pagodes, arrasta-pés). As palavras de Luiz Faria confirmam essa constatação sobre as duas tendências: “O Tião, em todos LPs que ele gravava, ele fazia questão de ser meio a meio, metade pagode [referindo-se aos gêneros mais caipiras], metade romântico". No entanto, observamos que na discografia do artista os gêneros caipiras predominam em relação aos de massa. (AMARAL, 2016, p. 151)

\footnotetext{
${ }^{67}$ Não foi possível constatar se o fonograma incluído no LP de estreia da dupla é o mesmo gravado para e lançado no disco $78 \mathrm{rpm}$ de 1957.
} 
Confirmando a observação de Amaral, Lucas Antonio Araújo também afirma que a dupla Tião Carreiro e Pardinho "se caracterizou [...] pela gravação de ritmos comuns à vertente considerada tradicional e, realmente, mesmo que estilizados, são estes ritmos os mais recorrentes em seu repertório" (ARAÚJO, 2014, p 124). Um outro ponto em que Araújo confirma Amaral refere-se ao fato de o repertório da discografia da dupla ser composto na proporção metade-metade: metade "gêneros mais caipiras", metade "romântico". Sobre este aspecto Araújo afirmou que a dupla, "que é identificada com os temas rurais e tradicionais, com o campo, tem no amor romântico, marcadamente nas desventuras amorosas, seu tema mais recorrente, ocupando praticamente um quarto" de seu repertório (ARAÚJO, 2014, p. 130). Aqui cabem duas considerações.

A primeira concerne à temática: conforme explicado por Araújo, na música sertaneja o tema da letra relaciona-se "em certa medida" ao ritmo da música (ARAÚJO, 2014, p. 128). Isso vale tanto para os gêneros mais tradicionais quanto para aqueles que foram incorporados pelo/ao gênero sertanejo. Assim, se na moda de viola, por exemplo, alguns dos temas mais recorrentes são a honra, o homem do povo, as injustiças dos "grandes" em relação aos “pequenos”, a morte trágica, a astúcia do caipira, a desconfiança em relação à modernidade sempre apresentados por narrativas épicas em histórias com começo, meio e fim que se ambientam predominantemente em paisagens rurais, com a preocupação de transmitir "lições de moral mais ou menos explícitas" por meio de personagens que representam idealmente "tipos associados ao passado e à formação da Nação" -, no pagode de viola a "autoexaltação do violeiro, visto como alguém capaz de proezas extraordinárias e exageradas" é a temática mais recorrente - algo "que se intensificou muito com a popularização do pagode de viola e que virou lugar-comum nas letras deste ritmo" (ARAÚJO, 2014, p. 240 e 238, respectivamente). Nesse contexto, o amor romântico e as desilusões amorosas (em grande parte dramatizadas por meio de histórias de traição e abandono) se consolidaram como temáticas atreladas às baladas e canções fundamentadas em padrões estéticos que posteriormente seriam descritos como "música brega" ou mesmo "romântica" 68 .

A segunda observação a ser feita diz respeito à notória presença desse "repertório romântico" dentro da discografia de Tião Carreiro e Pardinho, pois, a princípio, esse fato pode causar estranheza ou surpresa, uma vez que "a imagem comum que se faz de Tião Carreiro e Pardinho na literatura e na imprensa em geral” é de que a dupla se constitui, ao lado de Tonico e Tinoco, como a maior representante da tradição, seja pelo predomínio da

\footnotetext{
${ }^{68}$ Sobre as especificidades desta vertente ver ARAÚJO, 2014.
} 
"utilização dos instrumentos tradicionais, viola e violão" em todas as fases de suas carreiras ou em razão do repertório da dupla ser identificado e reconhecido, principalmente, por tratar preferencialmente dos "temas rurais e tradicionais" (ARAÚJO, 2014, p 124). Pelo menos dois motivos podem contribuir para esclarecer parte dessa questão.

Em primeiro lugar, a partir de uma perspectiva que privilegie uma visão mais mercadológica desta ocorrência, é factível supor que ao "fazer questão" de compor seu repertório "meio a meio", Tião Carreiro prenuncie ser detentor de uma consciência comercial aguçada, ou mesmo interessada. Talvez o que estivesse em jogo fosse de fato equilibrar inovação com tradição, ou mesmo gravar aquilo que vende ou está em voga sem precisar abrir mão daquilo que lhe é mais "caro", originário e válido enquanto índice identitário e de originalidade. Ao mesmo tempo, a postura de Tião, e a possibilidade não só de bancá-la como de torná-la efetiva, denuncia simultaneamente duas circunstâncias: 1) a fase ainda incipiente e de consolidação da indústria fonográfica até pelo menos o início da década de 1960 possibilitaria um maior controle do artista sobre aquilo que iria para o disco; 2) a partir de meados dos anos 1960 e principalmente após a década de 1970, uma vez consolidada e regida a partir de princípios mais afinados aos moldes e objetos de "uma moderna indústria do disco", alguns artistas, ou por desfrutarem de prestígio e reconhecimento - conquistados principalmente por altas vendagens -, ou por constituírem-se enquanto reserva de mercado, conseguiam estabelecer-se perante as insígnias e ditames desta indústria ${ }^{69}$. A reconhecida posição de destaque e relevância lograda e perpetuada por Tião Carreiro frente ao mercado, público e empresa fonográfica, dão ensejo para que as suposições acima possam ser consideradas como válidas. Confirmá-las ou não, entretanto, extrapola os limites e objetivos desta dissertação. De qualquer forma, vale citar um trecho, escrito por João Paulo Amaral, que colabora no sentido de dar alguma sustentação às hipóteses sugeridas acima. Assim escreveu o autor:

sobre a escolha de repertório e eventuais palpites e sugestões estéticas sobre os arranjos no momento das gravações, Mairiporã e Luiza Faria afirmam que Tião tinha pleno controle e autonomia em relação à sua gravadora, a Chantecler-Continental. Além disso, Mairiporã acrescenta que o violeiro

\footnotetext{
${ }^{69}$ Esta questão é extremamente bem descrita e discutida por Márcia Tosta Dias (DIAS, 2008) quando a autora se debruça sobre uma dinâmica que se tornou praxe a partir dos anos 1960 e perdurou por toda a década de 1970, momento no qual as empresas da indústria fonográfica dividiam e classificavam seu cast entre "artistas de catálogo" e "artistas de marketing".
} 
centralizava as decisões: "Repertório do Tião quem mandava era ele, e acabou". (AMARAL, 2016, p. 153)

Em segundo lugar, é preciso ponderar que, por mais que no contexto da música sertaneja a temática das letras estabeleça esta co-relação com o ritmo, o tema do amor romântico se coloca como universal, aparecendo de maneira transversal não só no âmbito da música sertaneja como em diferentes outras manifestações e expressões musicais, independente da época e local de suas origens. Desse modo, mesmo que este tema possa ser percebido em uma relação mais direta com as canções que se fundam nos ritmos menos tradicionais da cultura caipira, é seguro afirmar, e a própria análise - ainda que breve - das letras do repertório da dupla confirma, que esta temática permeia toda a produção de Tião Carreiro e Pardinho, aparecendo igualmente em canções que têm nas formas e ritmos caipiras mais tradicionais sua base. Sublinha-se, em adição, que isso é observável não só em relação ao repertório de Tião Carreiro e Pardinho pois, cabe lembrar, o amor "sempre foi um tema de grande apelo no interior da música sertaneja, desde as primeiras gravações de que se tem registro, a partir de 1929” (ARAÚJO, 2014, p. 130). Por fim, ainda sobre a presença, distribuição e equilíbrio entre temas, ritmos e gêneros dentro do repertório de Tião Carreiro e Pardinho, de acordo com o que afirmou Lucas Antonio Araújo, na discografia da dupla, geralmente, "o tema do amor se insere no primeiro lado do disco, o mais eclético, [mas] pode estar entre as canções consideradas tradicionais, aquelas que têm na viola de dez cordas seu instrumento base" (ARAÚJO, 2014, p. 130) ${ }^{70}$.

Tendo em mente as questões discutidas no parágrafo anterior, em adição aos fatos de que: 1) a moda de viola - "o emblemático gênero que muitas vezes serve para enumerar todo conjunto de gêneros que compõem a música sertaneja tradicional” (ARAÚJO, 2014, p. 184), sendo reconhecida e legitimada como "o gênero caipira por excelência" - se particulariza por ter no amor romântico, quando evocado, um tema que ocupa um lugar acessório ou secundário, tendo de modo geral uma presença diminuta ou mesmo (quase) nula dentro desta forma-canção; 2) que o tema do amor romântico, igualmente, não faz parte dos temas essenciais ao gênero do pagode de viola; é possível chegar-ser à conclusão de que, no repertório da discografia da dupla, "a quantidade de músicas que têm no amor romântico seu

\footnotetext{
${ }^{70}$ De acordo com Araújo (ARAÚJO, 2014.), na discografia de Tião Carreiro e Pardinho é padrão quase absoluto a inserção dos "temas românticos" e dos gêneros menos tradicionais no lado a do disco, ficando o lado $b$ reservado às músicas mais ligadas à tradição e/ou aos ritmos tradicionais da cultura caipira.
} 
tema só não é maior porque Tião Carreiro e Pardinho gravaram alguns discos dedicados somente às modas de viola e outros aos pagodes" (ARAÚJO, 2014, p. 184).

Dessa forma, sempre equilibrando inovação com tradição, ao construírem carreira, discografia e reputação com um repertório que, pelo menos em sua metade está fundamentado nos e marcado pelos temas, ritmos e gêneros mais ligados àquilo que se considera tradicional ou, no limite, como "mais original" dentro da música caipira, Tião Carreiro e Pardinho, já na década de 1960, eram considerados como legítimos representantes da "verdadeira" música sertaneja tradicional, tendo sua personalidade artística identificada com a tradição e o ruralismo. Esta percepção por parte de público, indústria, mercado, bem como a legitimidade da dupla enquanto "de raiz", aumentariam sobremaneira com o passar do tempo. Isso, por um lado, como reflexo de tudo o que seu repertório evocava, enaltecia, representava, perenizava; por outro, como resposta à ampliação da presença das influências exógenas e do desenraizamento pelos quais passaria a música sertaneja - principalmente de 1970 em diante com as figuras de Leo Canhoto e Robertinho. Diante deste cenário, desde os anos 1960 e durante as décadas de 1970 e 1980

os discos de Tião Carreiro e Pardinho, por exemplo, [seriam] considerados pertencentes à "tradição", comparados com duplas mais ousadas nas incorporações e mais abertas às sonoridades estrangeiras e modernas. (ARAÚJO, 2014, p. 204-205)

Não é sem razão, pois, que Tião Carreiro e Pardinho, desde muito cedo em suas carreiras (e até hoje), foram legitimados como mantenedores de uma tradição, sendo "descritos como a dupla que cantou a vida do homem do campo, dos 'caboclos' e a tensão desse homem rural em relação à modernidade e às mudanças" (ARAÚJO, 2014, p. 132). Esta reputação foi, como visto, construída a partir de uma discografia que sempre apresentou, em quantidade substantiva, um repertório que privilegiava formas, temas, lugares-comuns e especificidades tanto da música quanto da cultura caipira. Também contribuíram para tanto, evidentemente, a biografia, alguns traços estilísticos e escolhas estéticas da dupla, e as vicissitudes do processo histórico tanto da música sertaneja quanto da indústria fonográfica brasileira.

Acontece, porém, que diante das mudanças pelas quais passava a música sertaneja durante a década de 1960, mais do que manter uma tradição, Tião Carreiro e Pardinho foram decisivos para redefini-la, "no sentido de [estabelecer] padrões do que pode ou não ter esta 
posição de tradicional na música sertaneja, em um contexto de novas influências e modernizações que se intensificam ainda mais a partir da década de 1960, no interior do gênero" (ARAÚJO, 2014, p. 122).

Conforme discutido anteriormente, é incontestável o fato de que "a música sertaneja passou por significativas transformações no decorrer da década de 1960" (ARAÚJO, 2014, p. 200), sendo este "também o período de definição de certas características gerais que permaneceram até os dias atuais, do que pode ser considerado, entre público e artistas, como pertencente ao gênero musical conhecido hoje em dia como 'música de raiz"” (ARAÚJO, 2014, p. 121). Dito de outra forma, o que estava em discussão e disputa era: 1) quais seriam os parâmetros e os elementos definidores daquilo que poderia ou não ser compreendido e aceito como tradicional, original; 2) o que poderia e o que deveria ser considerado como genuinamente representativo da música dos caipiras dentro da heterogênea unidade da música sertaneja; 3) por fim, quais artistas teriam legitimidade para encampar este discurso e esta estética, reunindo condições de dar-lhe materialidade, alcançar reconhecimento e prestígio, razão de ser.

Conforme estudou Lucas Antonio Araújo, esse "processo de definição tem Tião Carreiro e Pardinho como protagonistas" (ARAÚJO, 2014, p. 121). Partindo de, mantendo e ressignificando alguns dos mais essenciais pressupostos e paradigmas estabelecidos pelos (e a partir dos) pioneiros de 1929,

Tião Carreiro e Pardinho certamente tiveram maior influência na definição e nos desdobramentos posteriores da música sertaneja tradicional a partir de 1960, tanto pela intensificação da perspectiva nacional quanto pela crítica de suas narrativas ante a influência moderna e estrangeira na música brasileira, como pelas características estéticas, marcadamente a forma de cantar, e a maior exploração dos recursos da viola de dez cordas que se cristalizariam como identificadores do que seria a "genuína música sertaneja" no interior do gênero." (ARAÚJO, 2014, p. 125-126)

Não são poucas as referências que apontam e discutem a centralidade e a relevância de Tião Carreiro e Pardinho para a história e a linguagem (ou para as linguagens) da música sertaneja, em particular, e popular brasileira como um todo. É consenso entre seus pares, profissionais da indústria e mercado do disco, jornalistas, críticos, público, acadêmicos que, independente de época, fase, contexto histórico, enfoque, pontos de vista, argumentos, Tião 
Carreiro e Pardinho são um dos mais importantes acontecimentos da música popular brasileira do século XX.

Tiveram grande sucesso comercial entre as décadas de 1960, 70 e 80 e são bastante populares entre o público do gênero em geral, até os dias atuais. São figuras centrais, protagonistas da definição dos padrões daquela que denominamos música sertaneja tradicional. As duplas posteriores que se identificariam com Tião Carreiro e Pardinho, teriam no estilo sertanejo tradicional uma referência muito maior do que Tonico e Tinoco [...]. (ARAÚJO, 2014, p. 125) 


\section{5 "O mineiro e o italiano"}

Escrita por Teddy Vieira em parceria com Nelson Gomes, a canção "O mineiro e o italiano" enquadra-se no gênero musical designado moda de viola, apresentando, se não todos, a maioria dos elementos estético-estilísticos que o caracterizam e singularizam.

Dentro do amplo e multifacetado repertório de Tião Carreiro e Pardinho esta composição se destaca: seu fonograma, quando submetido a uma análise crítico-interpretativa em que a estrutura interna da canção é confrontada com o andamento do processo histórico, apresenta um interessante poder de síntese.

É possível perceber que em "O mineiro e o italiano" estão postos em evidência ou sugeridos, de uma só vez, um significativo número de características, valores, processos históricos e experiências inerentes à cultura caipira e à Paulistânia.

Apontar, descrever, analisar e interpretar "o que" e "como" isso tudo está sintetizado nesta canção e em seu fonograma, sugerindo e interpretando seus possíveis sentidos, é tarefa para o próximo capítulo. 
O mineiro e o italiano viviam às barras dos tribunais,

Numa demanda de terra que não deixava os dois em paz.

Só em pensar na derrota o pobre caboclo não dormia mais.

O italiano roncava: nem que eu gaste alguns capitais,

Quero ver este mineiro voltar de a pé pra Minas Gerais.

Voltar de a pé pro mineiro seria feio pro seus parentes.

Apelou pro advogado: fale pro juiz pra ter dó da gente.

Diga que nós somos pobres que meus filhinhos vivem doentes,

Um palmo de terra a mais para o italiano é indiferente. Se o juiz me ajudar a ganhar lhe dou uma leitoa de presente.

Retrucou o advogado: o senhor não sabe o que está falando,

Não caia nessa besteira senão nós vamos entrar pro cano.

Este juiz é uma fera caboclo sério e de tutano, Paulista da velha guarda, família de 400 anos. Mandar a leitoa pra ele é dar a vitória pro italiano. 
Porém chegou o grande dia que o tribunal deu o veredicto.

Mineiro ganhou a demanda o advogado achou esquisito.

Mineiro disse ao doutor: eu fiz conforme lhe havia dito.

Respondeu o advogado que o juiz vendeu e eu não acredito.

Jogo meu diploma fora se nesse angu não tiver mosquito.

De fato, falou o mineiro, nem mesmo eu to acreditando,

Ver meus filhinhos de a pé meu coração vivia sangrando.

Peguei uma leitoa gorda, foi Deus no céu me deu esse plano,

De uma cidade vizinha, para o juiz eu fui despachando. Só não mandei no meu nome, Mandei no nome do italiano.

Um mineiro, um italiano, uma demanda de terra. Um advogado, um juiz quatrocentão, um veredicto inesperado. A corrupção no horizonte das (im)possibilidades, a astúcia como alternativa à subversão da ordem e garantia da sobrevivência.

A partir dessa matéria-prima Teddy Vieira e Nelson Gomes construíram uma estrutura e um enredo por meio dos quais o conteúdo sintético e os sentidos de "O mineiro e o italiano" exprimem-se tanto de forma objetiva quanto subjetiva. Esse fato é observável na narrativa de sua letra e em seus elementos musicais (forma, ritmo, melodia, harmonia, instrumentação, prosódia, interpretação).

Tendo em vista que "não é a representação dos dados concretos particulares que produz, na ficção, o senso de realidade, mas sim a sugestão de uma certa generalidade que olha para os dois lados e dá consistência tanto aos dados particulares do real quanto aos do mundo fictício" (CANDIDO, 2016) e que, "para a abordagem crítica do tipo de linguagem sobre a qual estamos pensando, 'levar em consideração apenas o conteúdo manifesto, e não o 
conteúdo implícito, é deixar passar o essencial"' (SANT'ANNA, 2009, p. 318), a análise e a interpretação apresentadas por este capítulo consideram, com igual importância, os aspectos objetivos e os subjetivos, a conotação e a denotação, contidos no fonograma que serve de objeto a este estudo.

Considerada uma das formas musicais mais características da música caipira (ARAÚJO, 2014, p. 129; FAUSTINO, 2007, p. 227), a moda de viola, em geral, “é de fundo dramático, conta casos” (ANDRADE, 1999, p. 342-343). Mário de Andrade já havia notado e descrito que um dos traços essenciais da moda de viola era "o conteúdo narrativo que elas apresentavam” (GONÇALVES, 2013, p. 283). Segundo ele, "a moda se distingue por ser o reconto dum caso qualquer mais ou menos sensacional, ou dum fenômeno importante da vida quotidiana, historiado" (ANDRADE, 1999, p. 342-343).

Esses casos quotidianos historiados, no mais das vezes, estão estruturados a partir de narrativas muito descritivas e lineares (GONÇALVES, 2013, p. 284), que contam "histórias épicas com começo meio e fim e, normalmente, [apresentam] uma preocupação em conferir veracidade aos acontecimentos narrados, com menção de lugar e hora, que faz com que alguns ouvintes creiam se tratar de 'histórias reais"” (ARAÚJO, 2014, p. 129).

Além disso, os enredos, em geral, contém "lições de moral mais ou menos explícitas", são predominantemente ambientados em paisagens rurais, "principalmente da pecuária e da vida em pequenas propriedades e fazendas, e os personagens são representantes de tipos associados ao passado e à formação da Nação" (ARAÚJO, 2014, p. 240).

Pois muito do que acaba de ser elencado como definidor e essencial ao conteúdo literário do gênero moda de viola pode ser percebido em "O mineiro e o italiano". Nessa canção, "os autores colocam nos versos um quadro progressivo de imagens, hábitos e compreensões" (SOUSA, 2008, p. 153), mencionando ou fazendo alusões a importantes episódios da vida cotidiana dos personagens, a partir de uma narrativa descritiva e linear.

Sua feição descritiva é reforçada pelo fato de que as ações e acontecimentos são, via de regra, pormenorizadas pelo narrador e, os personagens, sem nomes próprios, são todos adjetivados: o mineiro, o italiano, o advogado, o juiz quatrocentão, que é uma "fera", "caboclo sério e de tutano", a família que é pobre, a leitoa que é "gorda". Até mesmo o estar doente, condição por definição passageira, torna-se uma situação adjetivável dada sua permanência: os filhinhos "vivem doentes".

Ambientada predominantemente em uma paisagem rural, sua narrativa conta uma história que tem começo, meio e fỉm, concebida a partir da apresentação cronológica dos fatos e ações que a constituem, que lança mão de personagens-tipo que podem ser facilmente 
associados ao passado e à formação do Brasil (principalmente de sua região Centro-OesteSul).

Em relação ao local e à hora desse caso historiado, algum lugar da Paulistânia, entre o final do século XIX e a primeira metade do XX, parece ser a resposta mais adequada. Isso porque, apesar da letra dessa canção não fazer menção direta à Paulistânia, conforme adiantado na introdução desta dissertação, a força evocativa e o potencial sugestivo do fonograma dessa moda de viola produzem uma síntese que revela e/ou pressupõe elementos característicos e aspectos importantes ligados à história e à experiência do caipira e de sua cultura. Ao mobilizar todo um conjunto de personagens, signos e símbolos, a letra dessa canção traz à tona valores, experiências, relações, agruras, conhecimentos (materiais e imateriais) típicos dos habitantes da Paulistânia. Em outras palavras, exprime modos de ser, ver e existir daquela sociedade ${ }^{71}$.

Em primeiro plano, no que se refere ao provável local onde se passa esse caso historiado, o personagem mineiro parece contribuir para sustentar a ideia de que o drama contado toma lugar em algum ponto da Paulistânia. Isso porque a trama de "O mineiro e o italiano" é tecida a partir de elementos, imagens, hábitos e compreensões que apresentam a figura do mineiro como alegoria do tipo social designado como "caipira"72.

Conforme apresentado pelo capítulo I, a Paulistânia é o berço da cultura caipira, e não seria exagero assumir que seu traçado (bem como o de sua cultura e população) se expandiu, abrangeu e cobriu uma vastíssima área geográfica que, dentre outras, incluía partes significativas do território que atualmente forma o Estado de Minas Gerais. É nesse sentido que, conquanto de maneira genérica, Câmara Cascudo designa o caipira "como [o] habitante do interior brasileiro, mais especificamente o paulista e o mineiro" (SETUBAL, 2005, p. 32). Logo, o fato desse personagem ser "mineiro", a priori, não o torna menos caipira.

Auguste de Saint-Hilaire também escreveu sobre os mineiros. Em seu texto, o mineiro é descrito sob tom elogioso e "a cada passo sobreposto ao paulista". Mas, conforme bem percebeu Antonio Candido, quando o tom do francês era elogioso e suas linhas retratavam um tipo-social oposto ao do paulista, é forçoso compreender que o naturalista viajante se referia ao mineiro dos centros urbanos, das Minas Gerais do ouro e diamantes, não ao mineiro caipira paulistânico. De acordo com o que escreveu Candido,

\footnotetext{
${ }^{71} \mathrm{O}$ mesmo se dá quando o foco da análise recai sob os elementos musicais que configuram a gravação realizada por Tião Carreiro e Pardinho, assunto que será tratado no item final deste capítulo.

${ }^{72}$ Essa afirmação será desenvolvida e aprofundada em item subsequente deste capítulo.
} 
esquecendo as divisões administrativas, notemos que o mineiro, por ele [Saint-Hilaire] tão gabado e a cada passo sobreposto ao paulista, não é indiscriminadamente o natural das Minas Gerais; é, sobretudo, o habitante de suas áreas centrais, relativamente urbanizadas, beneficiadas pelo surto civilizador da mineração, ligadas à capital do país. O habitante do sul e do oeste de Minas, pelo contrário, despertaram-lhe, por sua vida rústica e pouca educação, o mesmo desagrado que o paulista. É que eram populações disseminadas, vivendo, os pobres, da agricultura de subsistência; os remediados, da pecuária atrasada - sem núcleos urbanos, conforto nem polidez. Aproximavam-se, inclusive étnica e historicamente, do caipira paulista, de quem se originam muitas vezes, e com o qual mantêm contato incessante, pelas migrações que os vêm trazendo a São Paulo de tornaviagem, há mais de um século. (CANDIDO, 2017, p. 53)

Aqui, uma vez mais, o simples fato de ser "mineiro" não torna esse personagem da moda de viola menos caipira; tampouco faz dele um paulistânico em menor grau, pois, “independentemente dos recortes político-geográficos atuais”, quando o que está em jogo é a cultura caipira, a experiência e o processo histórico inerentes às antigas porções territoriais que compunham a Paulistânia, no mais das vezes o que está em questão são os referenciais e a historicidade que dizem respeito a "uma área que possui continuidades históricas e culturais" (DÓRIA, 2018, p. 44).

Por fim, embora a letra de "O mineiro e o italiano" não contenha nenhuma menção direta à origem do mineiro, ou às porções territoriais de Minas Gerais que antigamente integravam a Paulistânia, a saber, as regiões do Triângulo Mineiro e do sul de Minas Gerais, seus elementos constitutivos e coesivos dão indícios, ensejam e/ou inspiram as inferências apresentadas até aqui; o que leva à interpretação de que o mineiro é paulistânico e caipira.

A presença do italiano contribui igualmente para reforçar a sugestão do local onde se ambienta a narrativa, dado que os mais de um milhão ${ }^{73}$ de italianos que entraram no Brasil se dirigiram, em esmagadora maioria, às fazendas de café que à época da "grande imigração" se espalhavam por significativas partes da região paulistânica (PETRONE, 1978, p. 100; RIBEIRO, 2006, p. 360 e 367; BIGAZZI, 2006, p. 82).

Esse dado, para além de sua indicação geográfica, propõe algo, também, em relação ao tempo histórico da narrativa. De sua parte, o imigrante, principalmente sendo ele um

\footnotetext{
${ }^{73}$ Dados estatísticos apontam que cerca de 1.156 .472 italianos imigraram para o Brasil durante o período da "grande imigração" (PETRONE, 1978, p. 100).
} 
imigrante italiano, sinaliza a hora da virada do século XIX para o XX, momento em que "muitos grupos étnicos, sobretudo europeus, vieram como colonos para trabalhar nas fazendas de café", sendo que "nenhum deles foi tão numeroso como os italianos, obrigados a deixar o país pela situação de guerra e de miséria em que se encontravam no final do século XIX” (CAMARGO, 2004, p. 138). Contribuem para reforçar essa proposta de recorte temporal a presença de um advogado, "profissão atrelada à modernidade e aos avanços liberais" (MANOEL, 2016, p. 99), e o fato de uma demanda por terra na Paulistânia chegar ao e ser decidida por meio de um Tribunal.

Em relação ao tempo da narrativa dessa moda de viola, se é válido afirmar que as ideias de progresso, modernização, civilização são fenômenos ligados à esfera urbana e têm na burocratização institucional um de seus objetivos e consequências, a presença do advogado e a do juiz reforçam o argumento de que a história cantada se passou entre o final da Monarquia e início da Primeira República, período em que, para São Paulo (e para alguns pontos de sua ampla região de influência cultural e econômica), os ideais de urbanização e de modernização começam a se tornar hegemônicos. De acordo com Maria Alice Setubal,

\footnotetext{
o imaginário paulistano é pautado, a partir de meados do século XIX, pelas idéias de progresso e modernidade. Essa concepção foi mais amplamente difundida a partir da República, com o repúdio das elites ao passado colonial e imperial, considerado como formas atrasadas de vida. (SETUBAL, 2005, p. 40)
}

A partir disso, portanto, "no final do século XIX e começo do século XX, o conceito de civilização [já era] considerado como o grande objetivo a ser atingido pelas elites brasileiras, especialmente a carioca e a paulista" (SETUBAL, 2005, p. 40). E, com o ideal do conceito, um processo de urbanização e modernização se seguia, trazendo à baila novas profissões, relações sociais, instituições, realidades. Um dos epicentros desse processo foi a capital paulista, que no "início do século XX assiste a um surto de urbanização e modernização" (SETUBAL, 2004, p. 81-82). Mas, com o decorrer do século XX, seus avanços e efeitos foram ganhando capilaridade, espalhando-se paulatinamente pelo interior e pelas regiões mais afastadas que outrora compunham a Paulistânia.

Assim é que, na ocasião onde a questão em pauta é: “que horas eram” quando “o mineiro e o italiano vivam às barras dos tribunais"?, o advogado e o Tribunal de Justiça reforçam a indicação temporal sugerida pela presença do italiano. 
O juiz quatrocentão, por sua vez, ao acumular as prerrogativas de ser, simultaneamente, juiz e "quatrocentão", sugere não só a Paulistânia (local) e esse processo de modernização (hora), como também uma das consequências do próprio avanço e afirmação deste nas primeiras décadas do século XX. Segundo o Dicionário Caldas Aulete, "quatrocentão" é adjetivo que qualifica aquele ou aquilo "que é de origem paulista muito antiga". De acordo com Dionísio da Silva, esse termo ganhou força e sentido "a partir da década de 1930, especialmente [com a] Revolução Constitucionalista de 1932”, tendo sido, provavelmente, José Alcântara Machado de Oliveira o "primeiro a registrar a palavra como qualificativo da elite paulista" (SILVA, 2004, p. 672).

Se o grau aumentativo com que o adjetivo foi dicionarizado carrega em si, embutida, "uma concepção de poder" (SILVA, 2004, p. 672), por outro lado dissimula e combate a perda desse mesmo poder! É que, “com o processo de modernização, intensificado com o advento da República, são postas em xeque as relações sociais senhoriais baseadas em vínculos mais personalistas, de submissão e favor" (SETUBAL, 2004, p. 82). Esse processo vai se acentuando ao longo das primeiras décadas do século XX e,

a partir dos anos 1930, com o declínio da lavoura do café, [...] trouxe como consequência o deslocamento final do poder econômico e político da oligarquia de origem rural para setores essencialmente urbanos, que já se encontravam na cidade ocupando cargos políticos e desenvolvendo atividades ligadas ao comércio, às finanças e à indústria. (SETUBAL, 2004, p. 81-82)

Frente a essa conjuntura,

a manutenção da posição de poder da elite de origem agrária na estrutura social se dá mediante estratégias matrimoniais, pela obtenção de títulos de "doutor" e, ao mesmo tempo, com a continuidade de uma extensa rede social tecida em épocas anteriores. (SETUBAL, 2004, p. 81-82, grifos meus)

Conforme se desenhava esse cenário e avançavam essas circunstâncias, ecoando e, dessa feita, amplificando uma prática observável desde os tempos coloniais (PRADO Jr., 2011), não foram poucos os fazendeiros que "se fizeram" juízes e/ou financiaram os estudos de seus herdeiros que, num futuro nada distante, comporiam a elite bacharelesca dos 
“doutores advogados” da Primeira República (e para além dela).

Composta a partir de elementos (aparentemente) simples, por meio das relações e síntese que apresenta, "O mineiro e o italiano" expõe uma sociedade em que os limites entre o público e o privado não estão claramente estabelecidos nem firmados, e em que o arcaico e o moderno convivem imiscuídos na mesma paisagem, informando e regendo realidades díspares e coexistentes.

Daí o mineiro apelar para a compaixão do juiz como forma de justificar sua razão na demanda e obter ganho de causa no processo: "fale para o juiz pra ter dó da gente". Esse trecho da letra, somado aos "diga que nós somos pobres" e "que meus filhinhos vivem doentes", ao mesmo tempo que apelam para a empatia do juiz como forma de garantir uma decisão favorável ao mineiro, reforçam e nos remetem às práticas e relações sociais senhoriais baseadas em vínculos mais personalistas, de proteção, submissão e favor, que pautaram a vida da sociedade brasileira durante séculos.

Ao planejar sensibilizar o juiz e oferecer-lhe uma leitoa como presente/recompensa pelo favorecimento na causa, o mineiro, por meio dessa estratégia, projeta na esfera pública valores e práticas da esfera íntima, se enquadrando, assim, nos termos da cordialidade, definidos por Sérgio Buarque de Holanda (HOLANDA, 1995).

Muito embora essa estratégia faça sentido e tenha potencial eficácia dentro da sociedade caipira, o advogado adverte que, neste caso específico, o juiz quatrocentão é um homem que não se pauta pela cordialidade. Dito de outra maneira, para o advogado, o juiz não é um homem cordial. Antes, aquele quatrocentão é adjetivado como "uma fera", definindo-se por uma aspereza que não se sensibiliza com "filhinhos [que] vivem doentes"; é um "caboclo sério", que se pauta pela seriedade da lei, não pela consideração de que "um palmo de terra a mais" fará ou não fará falta a alguém. Em suma: trata-se de um homem moderno, um representante da moderna elite da Paulistânia que, sendo uma pessoa "de tutano", tem brios para sustentar a sua decisão não importa a quem doer e que não rege sua conduta a partir dos modelos de sociabilidade arcaicos.

Por fim, ao apresentar o juiz como um "Paulista da velha guarda" proveniente de uma "família de 400 anos", o advogado está elogiando a tradição e, por conseguinte, afirmando que o juiz, em oposição ao caipira e ao italiano, por direito de nascimento, se posiciona na sociedade em lugar superior. Assim é que, mesmo sendo um "caboclo" (ou seja, um mestiço, 
um caipira), o juiz é um "caboclo caipira" social e hierarquicamente superior se comparado ao mineiro (também caboclo mestiço e caipira, mas que não nasceu em uma família quatrocentona), e ao italiano (que chegou, afinal, há pouco, não tendo ainda raízes fincadas na tradição local). Em suma, a narrativa, por meio do advogado e por meio do seu desfecho, faz o elogio da tradição paulista "de 400 anos". Para além disso, ao estabelecer as relações hierárquico-sociais entre os personagens balizando-se em critérios de nascimento, nesse elogio à tradição o advogado sinaliza para os traços arcaicos que também conformam e informam a história e o lugar social do juiz: um homem que traz em si o moderno sem se desvencilhar por completo do arcaico.

A partir dessa lógica e estrutura, o humor da narrativa é construído ancorado no fato de que o mineiro, informado disso tudo pelo advogado, age espertamente: ao enviar a leitoa no nome do italiano, o mineiro sabia que estava garantindo a vitória na demanda. E, daí, o mosquito no angu: o juiz recebeu a leitoa como um presente do italiano e decidiu pelo mineiro a fim de mostrar que não aceitava suborno; não aceitava porque era "uma fera", porque era um "caboclo sério", porque tinha "tutano", porque vinha de uma "família de 400 anos", com lugar superior na sociedade.

A linearidade, como dito no início deste capítulo, é uma das características fundamentais da estrutura narrativa das modas de viola. Em "O mineiro e o italiano", no entanto, há uma ruptura da linearidade com que a história é contada. Essa quebra da linearidade da narrativa, porém, não se configura como um elemento descaracterizador de sua forma. Isso porque, além de ocorrer uma única vez, essa quebra tem o objetivo claro de não inviabilizar a anedota que traz consigo a subversão da ordem e a suspensão do lugar-comum, que são reveladas ao final da narrativa. Como se verá adiante, o humor é característica fundamental da cultura e da música dos caipiras. E, nessa canção composta por Teddy Vieira e Nelson Gomes, é justamente através da piada que a lição de moral e o conteúdo épico outros dois ingredientes primordiais da moda de viola - são transmitidos ao ouvinte-leitor.

Enquanto aquilo que há de épico se apresenta pelo ato heroico do mineiro que, astutamente (e com a ajuda de Deus), ganha a demanda, salvando sua família e preservando sua honra, a lição de moral veiculada por essa moda resgata o enredo de um lugar-comum bastante conhecido: a vitória do pequeno contra o grande, do mais fraco perante o mais forte, numa inversão de lógica que remonta aos longínquos tempos bíblicos de Davi e Golias, e se 
faz presente em praticamente toda a tradição da literatura ocidental

Voltando às questões que concernem às paisagens e aos tempos de " $\mathrm{O}$ mineiro e o italiano", embora o cenário dessa narrativa não possa ser considerado completamente rural, uma vez que, conforme desenvolvido há pouco, as presenças do advogado, do juiz e, por extensão, do Tribunal de Justiça, remetem a profissões, estruturas e instituições da burocracia citadina, no caso contado por essa moda de viola fica evidente que é o espaço geográfico rural que enseja e dá sentido àquilo que é descrito pela história.

Desse modo, mesmo que diferentes espaços sociais, rurais e urbanos, estejam representados nessa letra, em seu universo "os espaços urbanos nada mais são que pontos de apoio às roças, portanto, de utilidade secundária na sobrevivência e na cultura [...]. Trata-se de um mundo rural" (FRANCISCO, 2004, p. 31).

Assim, deduz-se que os elementos citadinos contidos na ou sugeridos pela letra, são coadjuvantes e servem, talvez, mais como marcadores de tempo do que de lugar, conforme se procurou demonstrar.

A partir de uma estrutura narrativa em que a dimensão relacional entre os personagens aparece em primeiro plano, o conflito em torno de uma demanda de terra serve de pano de fundo para o desenvolvimento da trama de "O mineiro e o italiano".

Em uma história que "se afinca em tipos bem marcados funcionalmente" (SANT'ANNA, 2009, p. 320), a partir de personagens-tipo e por meio de valores, noções e lugares-comuns "característicos ao extremo", a narrativa da letra de "O mineiro e o italiano" apresenta relações entre classes sócio-econômicas díspares e sintetiza certos "pormenores" de uma "sociedade contraditória", percebida, captada e descrita por meio das vicissitudes de seu processo histórico (SCHWARZ, 1987, p. 19).

Seja por meio dos personagens e das instituições nela representadas ou pelos conflitos e relações sociais, econômicas e de poder que expõe/infere, seus sentidos são elaborados ou sugeridos a partir de figuras "dotadas não só de alma cultural e funcionalidade social, mas também de individualidade, que se projetam em símbolos de classes e de indivíduos" (SANT'ANNA, 2009, p. 320). 
A seguir, este texto verticaliza alguns pontos e sentidos que são explicitados ou sugeridos por esses ingredientes que se constituem enquanto célula básica sobre a qual trabalham os autores de "O mineiro e o italiano". 


\subsection{São todos caipiras!}

De acordo com Antonio Candido, o vocábulo caipira exprime "desde sempre um modo de ser, um tipo de vida, nunca um tipo racial" (CANDIDO, 2017, p. 27). A partir desse entendimento, o autor emprega o termo para se referir aos aspectos culturais de um tipo social que se originou e se perpetuou na "área de influência histórica paulista", como resultante de um processo histórico que observou "acentuada incorporação [de] diversos tipos étnicos ao universo da cultura rústica de São Paulo - processo a que se poderia chamar acaipiramento, ou acaipiração, e que os integrou de fato num conjunto bastante homogêneo" (CANDIDO, 2017, p. 27).

No interior desse conjunto culturalmente homogêneo, que foi se consolidando a partir dos vários grupos étnicos e experiências que a Paulistânia acolheu e acaipirou, foram se formando classes sociais e econômicas distintas. Em um processo de estratificação sócioeconômica que se acentua a partir do advento da mineração, "esta diferenciação de camadas, pelo nível econômico e as formas de participação cultural, não decorreu necessariamente de uma diferença social na origem dos grupos” (CANDIDO, 2001, p. 104). Conforme escreveu o autor de "Os parceiros do Rio Bonito", “o fazendeiro abastado, o pequeno agricultor, o posseiro [provinham] as mais das vezes dos mesmos troncos familiares, e seus antepassados compartilhavam, originalmente, as mesmas condições de vida” (CANDIDO, 2001, p. 104).

Ademais, nesse processo de estratificação e diferenciação sócio-econômica, os fazendeiros e "homens de prol" (FRAGOSO, 1998) que acabariam por formar uma classe econômico-social apartada daquela composta por sitiantes, posseiros e agregados, não deixaram, de partilhar, porém, os mesmos costumes, a "fala ou grau de rusticidade" das classes inferiores. Mesmo que, com o tempo, "acompanhando a evolução dos núcleos urbanos" as camadas superiores mostraram a tendência de se desligar da cultura caipira - ou mesmo negar seu pertencimento a ela -, é seguro afirmar que, uns mais "participantes" do que "integrantes", outros mais "integrantes" que "participantes", todos eram e permaneceram, em algum grau, caipiras, relacionando-se, partilhando e compreendendo crenças, festividades, lógicas, valores morais, éticas, saberes, visões de mundo (CANDIDO, 2001, p. 104-106). É nesse sentido que Antonio Candido admite que "há na sociedade rural de São Paulo formas diversas de participação na cultura rústica" (CANDIDO, 2017, p. 96). Assim, por mais que ao longo do processo histórico da Paulistânia a estratificação e a desigualdade social passassem a ser mais demarcadas e profundas, fazendo com que cada um desses grupos 
sociais fosse adquirindo características que os singularizavam e opunham, todos eles têm como chão comum, e mantiveram em algum grau, a cultura caipira.

Mais tarde, à época da "grande imigração" e da modernização urbano-institucionalburocrática experienciadas pela região paulistânica, parte desse processo e da dinâmica de acaipiração vai se repetir em bases muito similares. Num arranjo segundo o qual "a origem italiana não era impedimento para ser ou não caipira" (SETUBAL, 2005, p. 90), e "entre a vila e a roça havia certa unidade de comportamento, pois um espaço completava o outro" (FRANCISCO, 2004, p. 33), o imigrante acaipirou-se, durante significativo período de tempo a modernização não criou uma diferenciação significativa entre o campo e a cidade, e os cargos da administração, do judiciário continuaram a ser preenchidos por caipiras da elite.

Considerando esses preceitos e processos, e confrontando-os com os elementos, ações e relações representados e sintetizados pela narrativa de "O mineiro e o italiano", é possível (e plausível) inferir que os personagens da letra da moda de viola em questão representam tipos sociais surgidos e moldados sob a tessitura cultural que se fez comum à grande maioria dos habitantes da Paulistânia.

Assim sendo, se é válido que o mineiro, o italiano, o juiz quatrocentão e o advogado são personagens que dão vida a tipos e relações sociais que surgiram e foram perpetuados ao longo da experiência e do processo histórico da Paulistânia, é seguro afirmar que ser caipira e "paulistânico" é o denominador comum entre os personagens que figuram nessa moda de viola. Donde Romildo Sant'Anna, ao definir o “caipira de São Paulo”, o descrever como sendo o resultado e a somatória num mesmo território e região geográfica, grosso modo, “do caboclo nativo dos sertões paulistas" ${ }^{\text {"74 }}$, do mineiro que migrou "em busca de novas terras para sobreviver", do "roceiro itinerante e desbravador", do "italiano migrante logo acaipirado" (SANT’ANNA, 2009, p. 316).

Como parte do grande lençol de cultura caipira que se espalhou e consolidou por aquele vasto território e que, como visto, à despeito de suas variantes e variações locais e do processo de estratificação econômico-social por ele experienciado, foi capaz de manter em seus habitantes (participantes ou integrantes) um considerável nível de caipirice, as características e relações evocadas por esses personagens-tipo acabam por fornecer um microcosmo das relações sociais vividas pelos integrantes-participantes da cultura caipira. Em outras palavras, essas figuras explicitam, rememoram, ou sugerem certas relações típicas

\footnotetext{
74 “Este juiz é uma fera, caboclo sério e de tutano, paulista da velha guarda família de 400 anos”...
} 
daquela sociedade e cultura. São sintéticas neste sentido. Sitiante, fazendeiro, magistrado ou bacharel, são todos, em algum grau, caipiras.

Se o mineiro alegoriza o caipira posseiro-sitiante que vivia sob "formas mínimas de ajustamento" (CANDIDO, 2001), o italiano pode sugerir o imigrante que se acaipirou, e, indo além, o descendente de imigrantes que ascendeu social e economicamente, tornando-se fazendeiro de café. O juiz quatrocentão, por seu turno, representa uma elite formada ainda no período colonial, possível descendente de algum homem de prol; ou, ainda, provém daqueles setores que, a partir do declínio eminente de algumas aristocracias rurais, observado a partir de meados do século $\mathrm{XX}$, se organizaram e lançaram mão de diferentes estratégias para manter-se enquanto elite. O advogado - doutor do café, elite na república dos bacharéis -, é, quem sabe, filho de um fazendeiro conhecido do juiz, talvez um seu compadre, genro, correligionário político...

Como integrantes ou participantes, dando razão de ser e existir, desenhando e perpetuando a historicidade da cultura caipira, as relações, tipologias e lugares-comuns evidenciados ou sugeridos pela narrativa da letra de "O mineiro e italiano" colocam esses quatro personagens em pé de igualdade em pelo menos uma questão: são eles todos caipiras!

A seguir procurar-se-á apontar e interpretar em quais pontos a letra de "O mineiro e o italiano" contribui para sustentar essas afirmações. 


\subsection{Um mineiro paulistânico e caipira}

$\mathrm{Na}$ narrativa de "O mineiro e o italiano" a figura do mineiro pode ser entendida como a generalização do "tipo sociológico ideal" representado pelo conceito de "caipira" (CANDIDO, 2017). Isso porque esse personagem é construído a partir de elementos que sugerem a representação de um "caipira típico", que vive sob condições rústicas, num sistema fechado ou semi-fechado de subsistência que se baseia em soluções mínimas vitais e na posse da terra, tendo na honra, na família, na religiosidade e na astúcia os pilares mais fundamentais e norteadores de sua existência.

Conforme escreveu Antonio Candido,

o caipira típico foi o que formou esta vasta camada inferior de cultivadores fechados em sua vida cultural, embora muitas vezes à mercê dos bruscos deslocamentos devidos à posse irregular da terra, e dependendo do bel prazer dos latifundiários para prosseguir na sua faina. (CANDIDO, 2017, p. 95)

Se é correto considerar que o termo "camada inferior", empregado por Candido, é sinônimo de "camada mais pobre", é possível estabelecer uma primeira relação entre o personagem mineiro e o "tipo sociológico" do caipira: na narrativa da canção, esse é apresentado como pobre.

Não se afirma, com isso, que ser pobre é condição suficiente ou determinante para alguém ser caipira; tampouco se afirma que todo caipira é pobre! Mas, levando em conta os demais elementos e as relações que definem esse personagem nessa narrativa, sua condição de pobreza desponta como um bom indício de que esse mineiro representa um tipo de caipira que, na verdade, era o mais comum dentre a população paulistânica, uma vez que não ser pobre, naquela sociedade, era mais exceção do que regra. De acordo com Maria Sylvia de Carvalho Franco, historicamente os núcleos de povoação da Paulistânia formaram-se a partir de "famílias independentes, de sitiantes, proprietários ou posseiros" que dariam origem ao grosso da população de homens livres e pobres daqueles territórios, com "estilo de vida específico", “integridade de cultura e de organização social” (FRANCO, 1997, p. 33).

Ademais, se ser pobre contribui para que se considere esse personagem a representação de um tipo específico de caipira, seu pauperismo sugere uma realidade de “constante [...] dureza do trabalho e das condições da vida no campo," (SETUBAL, 2004, p. 
69). Essa dureza de condições, na letra, aparece na frase "meus filhinhos vivem doentes".

Estar doente constantemente pode indicar, por exemplo, falta de condições ideais de alimentação, vestuário (quando o frio aperta!), higiene, saneamento e acesso à saúde pública, algo não raro de se observar entre populações que têm por realidade uma "vida social de tipo fechado, com base na economia de subsistência" (CANDIDO, 2017, p. 44). Ora, não é difícil deduzir que uma vida pautada em mínimos vitais e regida pela sazonalidade e imprevisibilidades da natureza seja uma vida mais sensível às privações e infortúnios involuntários causados pelo clima, pelas doenças, pela carestia de alimentos e roupas. Dado que esse "mínimo vital" corresponde a um "mínimo alimentar", numa relação em que a "alimentação [é] apenas suficiente para sustentar a vida" (CANDIDO, 2017, p. 60), novamente é plausível depreender que uma população subnutrida é uma população pobre, e está mais sujeita a doenças e privações em seu desenvolvimento físico e anímico.

A dureza das condições de vida e trabalho do mineiro é sugerida, também, pelo fato de que, ao viverem doentes, seus filhos não podem ajudar na faina diária de seu núcleo familiar: uma das características gerais do caipira e de sua cultura, de acordo com Antonio Candido, é o trabalho doméstico (CANDIDO, 2017, p. 97). Esse, além de essencial à sua "vida social" - termo aqui compreendido como sinônimo de "satisfação de necessidades" (CANDIDO, 2017, p. 34) -, está estruturado na família e tem por particularidade o emprego ativo dos filhos no processo laboral. "Para os meios tradicionais caipiras, o núcleo familiar é de grande importância” (MANOEL, 2016, p. 112) e, tendo início desde tenra idade, a efetiva participação dos filhos nos afazeres e esforços que garantem a manutenção do núcleo familiar ao qual pertencem é essencial.

Perpetuando-se como "a referência principal de valores e do modo de organizar a vida [do caipira], [...] a família continua como centro das relações sociais e econômicas do pequeno lavrador até meados do século XX” (SETUBAL, 2004, p. 67 e 69), configurando e confirmando uma situação em que, para além dos filhos e da mulher, "o círculo dos parentes mais próximos [completa] a unidade fundamental de vida social" do caipira (SETUBAL, 2004, p. 69). Nesse sentido, a família é estrutura indispensável para que o caipira se reconheça (em sua identidade) e para que obtenha êxito em garantir seu equilíbrio de mínimos em relação ao meio ${ }^{75}$.

\footnotetext{
75 "Dir-se-á, então, que um grupo ou camada vive segundo mínimos vitais e sociais quando se pode, verossimilmente, supor que com menos recursos de subsistência a vida orgânica não seria possível, e com menor organização das relações não seria viável a vida social: teríamos fome no primeiro caso, anomia no segundo" (CANDIDO, 2017, p. 33).
} 
Daí que, para o mineiro, envergonhar seus parentes tem um peso muito grande. Ao fazê-lo, o caipira corre o risco de colocar em xeque toda uma rede de valores e relações que não somente pautam sua existência como também a tornam possível. Resultante de uma cultura em que se manter a dignidade é uma necessidade vital e na qual a bravura e a ousadia são valores altamente prezados (FRANCO, 1997, p. 54-55), "voltar de a pé pra Minas Gerais" causaria humilhação, vexame e desonra. Semelhante situação de constrangimento extrapolaria, no mais das vezes, a figura do mineiro, se estendendo a seu núcleo familiar e parentes próximos, gerando vergonha e repulsa que poderiam ensejar, por exemplo, abandono familiar ou negação de pertencimento por parte destes em relação ao mineiro. Sem os filhos para ajudar e sem poder contar com os parentes, o mineiro se veria na situação limite de não ser nem mesmo capaz de garantir sua sobrevivência.

Para piorar esse quadro, a possível derrota na demanda tira o sono do "pobre caboclo" pois resultaria, ademais, na perda de seu "palmo de terra". A terra, para o caipira, possui valor material e simbólico inestimáveis, uma vez que este "sempre foi o maior bem da cultura caipira" (MANOEL, 2016, p. 112). Conforme escreveu Maria Alice Setubal, na cultura caipira a terra

carrega [...] significados muito mais profundos que seu valor de produção ou de troca. No nível das representações, destaca a materialidade física da terra: lugar de viver, de morar, criar filhos e ser gente e, ao mesmo tempo, elo de ligação entre passado, presente e futuro, local da memória individual e coletiva. Enfim, é a terra da gente. (SETUBAL, 2005, p. 98)

Os depoimentos recolhidos por Moraes Silva ressaltam a terra como o alojamento das lembranças, local da memória e também como o primeiro acolhimento, o lugar protetor, de pertencimento e identidade. Também para aqueles que vivem no campo, a terra de alguma forma preserva esses valores. (SETUBAL, 2005, p. 98)

Assim, ao dado concreto de que sem a terra o mineiro perderia de imediato sua capacidade de subsistência soma-se o fato de que, privado de seu pedaço de chão, o caipira perde sua identidade, sua memória, sua história, seu futuro. Ao perder a demanda e se ver obrigado a "voltar de a pé pra Minas Gerais" o mineiro seria privado, de uma só vez, de seus 
valores mais caros e de seus bens mais estimados, ficando sem terra, sem família ${ }^{76}$, sem honra, sem identidade, sem condições de existir... O palmo de terra a mais, que para o italiano é indiferente, representa, para o mineiro, a diferença entre ser ou deixar de ser.

Ainda que, historicamente, o caipira tenha moldado sua existência pautada na mobilidade, pelos deslocamentos constantes e pela marca do provisório, os elementos da narrativa dessa moda de viola fazem crer que o mineiro vive em um tempo em que esta possibilidade já não se apresentava como disponível. É que esta mobilidade restauradora pressupõe abundância de terras desocupadas e baixa densidade demográfica ${ }^{77}$. A presença do imigrante, de uma certa burocracia institucionalizada representada pelo tribunal, pelo juiz e, principalmente, pelo advogado (bacharel da República?!), contribuem para sustentar o argumento de que o tempo dessa narrativa dista do tempo dos bandeirantes, dos caipiras seminômades que podiam deslocar-se incessantemente à busca de terras. Tudo leva a crer que o tempo dessa história situa-se num período onde a disponibilidade de terras já não se fazia abundante, estando a capacidade de deslocamento e reequilíbrio dos mínimos pela via da ocupação de outras terras virtualmente extinta enquanto possibilidade viável. Essas questões serão discutidas na sequência deste texto, principalmente no Capítulo III.

Para já, o interessante é notar que a maneira como o "causo" da demanda de terra é contado, para além do que já foi dito, também sugere a condição do mineiro em relação à terra pela qual luta. Não é descabido imaginar que o mineiro, como tantos caipiras, seja um posseiro pois, além de fazer alusão ao "funcionamento cordial da justiça" (ideia que será discutida adiante), a certeza da derrota demonstrada pelo mineiro dá a entender que ele não tem como provar legalmente que "o palmo de terra" em disputa a ele pertence. Conforme estudou Antonio Candido, a posse de terra era uma situação "bastante generalizada" dentro da realidade do caipira (CANDIDO, 2017, p. 98), a ponto da "posse, ou ocupação de fato da terra, [ter pesado] na definição da sua vida social e cultural” (CANDIDO, 2017, p. 98). Essa

\footnotetext{
${ }^{76}$ Uma vez que a migração favorece ou pode causar uma desintegração da unidade familiar (SETUBAL, 2004, p. 69).

77 "A vida social do caipira assimilou e conservou os elementos condicionados pelas suas origens nômades. A combinação de traços culturais indígenas e portugueses obedeceu ao ritmo nômade do bandeirante e do povoador, conservando as características de uma economia largamente permeada pelas práticas de presa e coleta, cuja estrutura instável dependia da mobilidade dos indivíduos e dos grupos. Por isso, na habitação, na dieta, no caráter do caipira, gravou-se para sempre o provisório da aventura” (CANDIDO, 2017, p. 45); “[...] estudos evidenciam que o mundo caipira começou a se estabelecer com a fixação das moradias no interior paulista, a partir das bandeiras que se adentravam no sertão. Alguns fatores exerceram nítida influência nesse processo: terra abundante, mobilidade constante, caráter aventureiro do mameluco e relação visceral com natureza" (SETUBAL, 2005, p. 20).
} 
condição de posseiro se caracterizava pela ausência de registro legal da propriedade, situação que expunha o caipira a "constantes expulsões da terra por falta de documentação" (SETUBAL, 2005, p. 20), deixando-o, como escreveu Antonio Candido, "a mercê dos bruscos deslocamentos" (CANDIDO, 2017, p. 95).

Sua condição de pobreza e isolamento também contribuíam para expor o caipira a essa situação jurídica em relação à terra: compelido a "formas de legitimação cartorial da posse" às quais eram a ele inacessíveis (RIBEIRO, 1995, p. 386), posto que "a autoridade pública [esteve] sempre [referida] a instituições alheias ao mundo caipira" (FRANCO, 1997, p. 34), não foram poucas as vezes que o caipira dependeu "do bel prazer dos latifundiários" para prosseguir na sua faina" (CANDIDO, 2017, p. 95) - ou da boa vontade de uma autoridade: "fale para o juiz pra ter dó da gente", diz a letra. E, conforme a região paulistânica experienciava o "avanço das condições capitalistas no campo" (SETUBAL, 2005, p. 20), a expropriação de terras de posseiros só fazia aumentar, pois

o latifúndio se formava à custa de proprietários menores, por compra ou espoliação - esta sempre fácil numa sociedade em que a precariedade dos títulos e a generalização da posse de fato desarmou o lavrador, na fase em que a expansão econômica passou a exigir os requisitos legais para configurar os direitos de propriedade. (CANDIDO, 2017, p. 94) 


\subsection{O italiano}

Conforme mencionado anteriormente, dentre as várias nacionalidades que imigraram para o Brasil, os italianos, vindo em massa, predominaram e, São Paulo ${ }^{78}$, acabou se tornando a região que absorveu o maior contingente daquele povo (RIBEIRO, 2006, p. 360 e 367; BIGAZZI, 2006, p. 82). Segundo escreveu Maria Tereza Schorer Petrone, São Paulo "não só dispunha de meios para subsidiar a viagem dos imigrantes, como contava com uma corrente espontânea de imigrantes, atraídos ou pelo sucesso de seus compatriotas ou pela propaganda que os cafeicultores e o próprio Estado faziam na Europa”, pois, como já foi dito, em grandes porções da antiga Paulistânia "a imigração destinava-se a fornecer principalmente braços para a grande lavoura" (PETRONE, 1978, p. 99, 100 e 103). Desse modo, “apesar do grande número de nacionalidades que vieram para São Paulo, quem marcou a vida na fazenda de café e a fisionomia das cidades foi, sem dúvida, o italiano" (PETRONE, 1978, p. 105) que, desde sua chegada, contribuiu para moldar não só a economia da região, como também sua cultura, costumes, modos de ser e ver (BIGAZZI, 2006; CASTELLANI, p. 107).

Acontece, porém, que "quando a Europa derramou multidões de imigrantes que acolhemos, [...] todos eles, ou quase todos, foram assimilados e abrasileirados". Por isso, se “a imigração estrangeira, principalmente de pobres trabalhadores brancos europeus [...] representou também uma enorme ameaça de transfiguração da população brasileira preexistente", sucedeu que, no Brasil, "encontrando uma sociedade já formada e etnicamente integrada, [essa multidão] apenas afetou seu destino, [...] transformando-se mais os recémchegados do que os que aqui viviam" (RIBEIRO, 1995, p. 73 e 259, respectivamente). Dito de outro modo, foi o imigrante que se "abrasileirou", e não o contrário.

Nesse processo de abrasileiramento, esses imigrantes italianos "mostraram grande abertura em relação ao modo de vida brasileiro, tanto que logo se assistiu a uma caipirização de seus costumes" (SETUBAL, 2004, p. 25), realizada por meio de uma "integração relativamente rápida dos italianos tanto em relação aos costumes e língua, como principalmente através dos casamentos com brasileiros/as" (SETUBAL, 2004, p. 74). Contribuíram para tanto o fato dos italianos "serem uma comunidade relativamente aberta ao processo de aculturação" e da religião de ambas culturas ser, predominantemente, a católica (SETUBAL, 2004, p. 29).

\footnotetext{
${ }^{78}$ E, por extensão, a Paulistânia, que com o passar do tempo e por meio da própria distribuição desse contingente de pessoas pelo território da região tornou-se a terra de grande número de imigrantes italianos.
} 
Dado que "na cultura e na sociedade caipira há não apenas permanência de traços dos traços que desde logo se estabeleceram como 'mínimo social' - mas retorno, perda de formas mais ricas de sociabilidade e cultura, por parte dos que se iam incorporando nela, a partir de grupos mais civilizados" (CANDIDO, 2017, p. 55-56), dos italianos que se acaipiraram, uma parcela regrediu culturalmente, acabando por se "tornar verdadeiros nômades, mudando-se ao final da colheita em busca de vida melhor, de melhores terras e condições de trabalho" (SETUBAL, 2004, p. 26).

Os que nessa busca obtinham êxito, aos poucos iam se tornando pequenos proprietários ou, dentro de uma ou duas gerações, fazendeiros. Os que não, no mais das vezes continuaram a viver sob os ditames dos "mínimos sociais", da sociabilidade estável e pouco dinâmica" (CANDIDO, 2017, p. 55-56) que correspondia e caracterizava a grande maioria da população caipira. Nestes, "a imagem do italiano pobre passou a indiferenciar-se da do caipira, consolidando tudo como um mesmo contingente de desanimados e oprimidos" (SANT'ANNA, 2009, p. 328). Naqueles, a mobilidade social, conforme mencionado, "acarretou a formação de uma camada de sitiantes e a ascensão de alguns deles à estrutura dominante" (SETUBAL, 2005, p. 37).

Conforme apontado por Durham, a grande mobilidade social de uma parcela dos imigrantes na zona rural se concretizou em razão de "alguns elementos [que] contribuíram para uma adequada adaptação e para o sucesso dos italianos" (DURHAM, apud SETUBAL, 2005, p. 37). Dentre eles destacam-se:

[o] conhecimento de técnicas de cultivo e plantio; [o] trabalho familiar, com a permanência dos filhos na casa mesmo depois de casados e a inclusão do trabalho feminino na lavoura; [o] espírito de poupança; mais oportunidades no comércio do mercado local por deterem esse conhecimento ou por valorizarem a educação; e a consequente possibilidade de aprendizagem nesse setor. (SETUBAL, 2005, p.37)

Alicerçados nesses rudimentos, organização e espírito, nas regiões da Paulistânia, "onde a maioria dos italianos empregava-se como colonos nas fazendas" (SETUBAL, 2005, p. 29), "o sonho de serem donos de um pequeno lote de terra geralmente se [tornava] possível graças a duras economias feitas durante a estada na fazenda de café" (PETRONE, 1978, p. 111). 
Como era permitido aos colonos manter roças de subsistência e criação de animais, o que excedia ao consumo familiar era vendido, trocado ou transformado. Foi o caso do milho transformado em fubá, costume que acabou se estendendo a todo o interior paulista. Isso permitia ao colono possuir uma reserva, para o objetivo da maioria deles: comprar uma pequena propriedade. (CAMARGO, 2004, p. 139-140)

Contribuía, também, para a consecução dessa aspiração, “o fato de possuírem uma concepção econômica da vida dirigida para o progresso e a valorização do futuro como conquista" (SETUBAL, 2004, p. 29).

Em São Paulo a mobilidade horizontal e vertical é um traço marcante do imigrante instalado na frente pioneira altamente especializada na produção para o mercado internacional. Começando como assalariado, participando de um dos traços típicos da vida paulista, ou seja, a mobilidade horizontal à procura de melhores oportunidades em outra fazenda, o imigrante mede seu sucesso pela ascensão à condição de pequeno proprietário, pelo abandono, portanto, da condição de braço assalariado. (PETRONE, 1978, p. 132)

Naturalmente, nem todos imigrantes foram capazes ou tiveram a chance de consumar sua mobilidade vertical. Da mesma forma, da fração que granjeou tornar-se pequeno proprietário de terra, apenas um pequeno número completou o caminho que levava ao topo da hierarquia sócio-econômica. Cabe ainda observar que, dentre os que locupletaram, nem todos provinham das regiões rurais ou tinham sido colonos; uma quota havia feito fortuna na cidade, principalmente na Capital paulista, por meio, por exemplo, de atividades comerciais. Mas, aqueles que conseguiram enriquecer, "se uniram num sistema semelhante ao ideal de vida bandeirante, nessas alturas em pleno reinado do café, a prevalecer a instituição colonial e imperial do baronato" (SANT'ANNA, 2009, p. 328). Os então "novos-ricos”, parte desses transmudados em latifundiários - "alguns [tornando-se] mesmo reis do cafe",79 (SANT'ANNA, 2009, p. 329) -, passaram a reivindicar e disputar, com a elite caipira nativa, os espaços sociais, as terras, os lucros, o poder. Instaurava-se assim, "pela similitude entre os caipiras nativos e a versão rural do carcamano - o 'polenteiro' -, um sentimento de classe

\footnotetext{
79 "Geremia Lunardelli, o 'rei do café', é talvez o melhor exemplo do sucesso desses imigrantes" (CAMARGO, 2004, p. 149).
} 
que se expressa em ressentimentos" ${ }^{\prime 0}$ (SANT'ANNA, 2009, p. 328). Com o tempo, o convívio inevitável nos espaços sociais da elite, os casamentos entre itálicos e quatrocentões, foram apaziguando os ânimos, de modo que "os italianos novos-ricos, claro, com exceções, fecharam-se em copas e adotaram a política da boa vizinhança com os barões nativos do café e capitalistas urbanos, estes na maior parte antigos fazendeiros" (SANT'ANNA, 2009, p. 329).

A letra de "O mineiro e o italiano", ao falar do italiano, não assinala precisamente sua origem ou classe social, nem indica de forma taxativa se esse imigrante é pobre, remediado ou um "novo-rico".

Dessa forma, a partir do que foi exposto por este item 2.3, e da leitura da narrativa dessa moda de viola, duas possíveis interpretações se apresentam como razoáveis: 1) o italiano como aquele imigrante que permaneceu pobre ou pequeno proprietário, disputando palmo a palmo a terra e a sobrevivência, com homens igualmente pobres, vivendo ambos sob condições mínimas dentro de uma rusticidade tipicamente caipira; 2) o italiano (ou um descendente de italiano) como a representação de um imigrante que ascendeu socialmente, passando de colono a fazendeiro, e que sob a lógica e a pressão dos avanços da cafeicultura disputava cada palmo de terra que pudesse aumentar sua produção, lucros, poder.

Como recém enunciado, apesar da letra da canção não oferecer elementos suficientes para se afirmar de forma taxativa que o italiano, mais do que o colono imigrante que

\footnotetext{
80 "A elite paulista, inicialmente, tentou singularizar-se, separando-se dos imigrantes através de escolas e clubes destinados exclusivamente àqueles que, anos mais tarde, teriam seus descendentes classificados como 'quatrocentões'. A despeito do seu esforço, essa chamada 'elite paulistana' e paulista, acabou por miscigenar-se aos imigrantes. Segundo Raymundo Faoro, em seu livro Os donos do poder, no início do século XX, muitos dos novos-ricos, habitantes da cidade de São Paulo, principalmente os de origem italiana ou japonesa, tinham sido colonos nas grandes fazendas de café dos quatrocentões. [Quando] as famílias tradicionais são afetadas pela queda da Bolsa de Nova York, em 1929, que derrubou os preços do café [...], os fazendeiros paulistas, chamados 'barões do café', nem sempre tendo o título legítimo de barão, não encontrando compradores para sua produção, empobrecidos, veem-se obrigados a vender algumas de suas fazendas. Em muitos casos, elas foram compradas por antigos empregados. Na peça teatral Os ossos do barão, de Jorge Andrade, a filha de um fazendeiro casa-se com um filho de colonos italianos, ex-empregados de seu pai. O rapaz, apesar de ter estudado e obtido um diploma de 'doutor', não tinha pedigree e só consegue ser recebido pela alta sociedade através do casamento com moça das famílias quatrocentonas que aceitavam o consórcio para dourar o brasão. Os conflitos gerados pela gradual miscigenação entre a aristocracia paulistana antiga e a emergente classe dos descendentes de italianos foram mostrados também pelo dramaturgo e contista Antônio de Alcântara Machado, um quatrocentão, que na obra Brás, Bexiga e Barra Funda, uma coletânea de contos publicada em 1928, trata do quotidiano dos imigrantes italianos e dos ítalo-descendentes na cidade, mostrando as impressões duma São Paulo imersa na experiência da imigração, que então vinha modificando os trejeitos da cidade." (fonte: https://pt.wikipedia.org/wiki/Quatrocentão, acessado em 31/03/2016)
} 
permaneceu pobre, simboliza aquele que se tornou cafeicultor fazendeiro, algumas passagens da letra sugerem esta interpretação mais do que a primeira.

Por meio da demanda de terra dramatizada pela letra, é possível captar uma referência (ou sugestão) à fazenda e à pequena propriedade ou posse. Esta, aparece representada pelo pedaço de chão do mineiro; aquela, pela terra do italiano disposto (e capaz) de gastar "alguns capitais" para ganhar a demanda. Ora, tendo em mente a história da estrutura fundiária e da desigualdade na distribuição de renda no Brasil, desde os tempos da Colônia, não é difícil supor (ou mesmo aceitar como evidente) que aquele que tem capitais à disposição para "comprar uma demanda" represente um fazendeiro e não um pequeno proprietário; representaria, ainda menos, um homem pobre livre e posseiro.

Independente da quantia de capitais em jogo, dentro da realidade da grande maioria da população que integrava a sociedade caipira, estar disposto a e/ou ter condições de dispor de dinheiro para resolver uma situação tal qual a narrada pela letra é índice seguro de pertencimento a uma classe sócio-econômica mais privilegiada.

Um outro dado da letra que sugere ser o italiano um fazendeiro, é a convicção de que "um palmo de terra a mais para o italiano é indiferente", expressa pelo mineiro. Ora, "um palmo de terra" para um caipira pobre e posseiro pode significar a diferença entre sobreviver ou não; para um pequeno proprietário, pode ser o tanto que lhe falta para que sua roça de subsistência, aumentada em um palmo, passe a gerar pequenos excedentes que tornem sua situação de remediado menos intermitente ou frágil; para o grande proprietário, conquistar (leia-se espoliar) "um palmo de terra a mais" significa, principalmente, aumentar seu poder de mando e controle, seus lucros e domínio político-administrativo. E, na Paulistânia, o latifúndio se “formava à custa de proprietários menores, por compra ou espoliação - esta sempre fácil numa sociedade em que a precariedade dos títulos e a generalização da posse de fato desarmou o lavrador, na fase em que a expansão econômica passou a exigir os requisitos legais para configurar os direitos de propriedade" (CANDIDO, 2017, p. 94).

A ganância, o sarcasmo e o apetite voraz demonstrados pelo italiano - que chegava a "roncar" de bravo e se dispunha mesmo a gastar uma soma de seu capital não só para ganhar a demanda como para desonrar e humilhar o mineiro, fazendo-o "voltar de a pé pra Minas Gerais" -, expressam, aparentemente, projetos, ideais e objetivos mais alinhados àqueles de alguém que é capaz de tudo pelo poder. A vilania e o pendor a corromper que fica sugerido na frase "nem que eu gaste alguns capitais", a fúria e a cobiça viperinas, de certa forma desproporcionais para ganhar uma disputa em que o que está em jogo é "um palmo de terra", não parecem ser compatíveis com a necessidade daquele que, humildemente quer melhorar 
sua condição e espaço de plantio ou, ainda, do posseiro agricultor que duramente luta pela subsistência em seu minguado espaço de chão.

Além disso, na narrativa, essas posturas e atitudes, demonstram, no italiano, uma ausência ou perda da noção e do valor da solidariedade vicinal, um dos aspectos mais caros e essenciais à cultura caipira e à sobrevivência de seus integrantes (CANDIDO, 2001). Postura, esta, típica das "das classes rurais abastadas que, participando cada vez menos, com o correr do tempo, na vida da própria vizinhança tradicional" (CANDIDO, 2017, p. 78), iam perdendo o senso de pertencimento, de reconhecer-se como um igual, o que, quase sempre, resultava num tipo de apagamento, segundo um processo no qual "os mais ricos [abandonavam] o sistema de cooperação vicinal, marcando assim a diferença crescente entre sítio e fazenda" (CANDIDO, 2017, p. 94).

Isso tudo contribui para que se perceba o personagem italiano como a alegoria daquele imigrante que ascendeu sócio-economicamente. Ora, se fosse o italiano um imigrante acaipirado que permaneceu pobre, ele teria provavelmente incorporado e mantido em seu cotidiano esse aspecto da cultura caipira (ou, no limite, não o teria esquecido ou negado).

Na letra, o comportamento do italiano demonstra uma postura que, na verdade, se configura como oposta à solidariedade e empatia para com o próximo.

Seu sarcasmo prazeroso de "ver o mineiro voltar de a pé pra Minas Gerais" colabora para esse entendimento. Ter prazer ou, pelo menos gosto, de ver o sofrimento alheio ser maior do que o necessário extrapola todos os níveis, mesmo que mínimos, de empatia, compaixão, solidariedade. 


\subsection{O juiz quatrocentão e o advogado aconselhador}

Ainda na colônia, à medida em que a fixação ao solo vai se avolumando, os bairros, as vilas e depois as cidades se formando, algumas "funções se tornam mais diferenciadas e exclusivas" (PRADO Jr., 2011, p. 311). Caio Prado Jr. cita o comerciante como exemplo. Segundo o autor, a partir do momento em que uma determinada aglomeração alcança certa importância, o comerciante deixa de ser comerciante "apenas nas horas disponíveis da lavoura" para sê-lo em tempo integral (PRADO Jr., 2011, p. 311). Essa especialização atinge igualmente os setores administrativos e a burocracia jurídica, de modo que "vão surgindo algumas autoridades fixas e permanentes, como o juiz que não é mais o simples fazendeiro a exercer o cargo nas horas vagas" (PRADO Jr., 2011, p. 311).

Acontece, no entanto, que essa especialização jurídico-administrativa, no Brasil, nunca significou a total separação entre o público e o privado (HOLANDA, 1995). Se o juiz, por um lado, deixou de exercer suas funções de forma intermitente, poucas vezes deixou de ser, por completo, o simples fazendeiro (que de simples tinha tão somente a rudeza de seus costumes, caipira que era).

É também ainda no período colonial que um tipo específico de absenteísmo se desenha e, com o desenrolar do processo histórico, torna-se regra: durante o período da safra e dos "maiores trabalhos rurais", os grandes proprietários residem nas fazendas; no restante do ano, "preferirão os prazeres e distrações da cidade", alternando, assim, seu local de residência entre um e outro. Em um espaço, tanto quanto no outro, "são os fazendeiros, senhores de engenho, grandes lavradores que formam a sua nata social” (PRADO Jr., 2011, p. 311).

Essa situação implica serem "os centros urbanos um reflexo das condições dominantes no campo. Os senhores rurais formam, aí também, a classe superior" (PRADO Jr., 2011, p. 312), numa estrutura que se perpetuaria sem maiores alterações, valendo como regra até os dias da Primeira República e, em alguns casos e regiões, para além dela. Daí que, para o caipira despossuído, a cidade e a vila se constituírem "como símbolos do poder local" (FRANCISCO, 2004, p. 37).

Baseada nessa estrutura e realidade, os quadros da administração pública e do sistema jurídico eram recrutados ou formados, desde a Colônia, a partir da elite latifundiária (PRADO Jr., 2011), como parte de um sistema que trazia em sua essência a prática rotineira de se negociar cargos públicos, "do peculato, do suborno e de todas as demais formas de corrupção administrativa" (PRADO Jr., 2011, p. 356-357). 
Ciente da sociedade em que vivia, o italiano cogita ganhar a demanda por meio da corrupção. Por mais que isso não apareça de forma direta na letra da canção, quando o personagem esbraveja que pretende ganhar a causa nem que para tanto tenha que gastar alguns capitais, insinua que a corrupção é uma saída ao alcance das mãos (ou dos bolsos...). Assim, a intenção (ou possibilidade real) de "comprar o juiz", ou, no limite, a sentença, fica sugerida pela passagem em questão; e remete a um modus operandi nada estranho à sociedade e ao processo histórico brasileiros.

Acontece, porém, que aquele juiz quatrocentão, na canção, é apresentado como "caboclo sério e de tutano, paulista da velha guarda", incorruptível, proveniente de uma "família de 400 anos". Dito de outra forma, o juiz, na narrativa, é descrito como um homem não cordial. Pautando sua conduta de acordo com princípios modernos, num claro elogio à modernidade paulistana e à elite quatrocentona - que seria o baluarte dessa modernização -, o juiz de "O mineiro e o italiano" é adjetivado de modo a situá-lo não só como elite mas também como um homem moderno, ilibado dentro de um sistema corrompido, como alguém capaz de representar uma modernidade que rompe e supera, inclusive, traços e heranças do Brasil Colonial.

Essa construção do juiz como um homem (paulista) moderno e corretíssimo é afirmada pelo advogado e absorvida pelo mineiro de maneira tão contundente e definitiva que esse é o dado que serve de matéria-prima para o plano redentor que confere, ao mineiro, a vitória na demanda de terra. 


\subsection{Uma demanda de terra sob os olhos da justiça de um mundo cordial}

Em uma sociedade em que o "uso dos aparelhos governamentais como propriedade privada" era realidade, a conduta do servidor público era orientada, em elevado grau, pelos "interesses de seu meio social". Maria Sylvia de Carvalho Franco explica que "essa diferenciação rudimentar entre função oficial e vida privada permitiu a extensão do poder oriundo do cargo público para a dominação com fins estritamente particulares". Nesse contexto, "o destino do homem pobre definiu-se num mundo regido por dois princípios divergentes de ordenação das relações sociais - associações morais e ligações de interesses que se articularam e tiveram efeitos deletérios recíprocos (FRANCO, p. 139, 122, 137, 110, respectivamente).

Nessa cadência, "a modernidade dos paulistas viveu no limiar de dois tempos, o que se quer ser e o que se é, mesmo não reconhecendo esse pertencimento. [Esse] é um dilema que se acentua à medida que vai chegando o século XX" (FRANCISCO, 2004 p. 40).

Pois essa divergência entre ordenações e seus (possíveis) resultados deletérios, bem como a expressão de uma modernidade incompleta estão presentes na narrativa de "O mineiro e o italiano". A canção interpretada por Tião Carreiro e Pardinho sintetiza e expressa relações e conflitos próprios a uma sociedade confrontada a um mundo regido pelos costumes justaposto - a todo momento - a outro regido pelo ordenamento jurídico, entre um arcaico e outro moderno.

No mineiro, essa relação se expressa quando ele demonstra não saber exatamente como se comportar ou como proceder perante a institucionalizada e burocrática lógica jurídica (por isso "precisa" do conselho do advogado). Mas, ao mesmo tempo, o mineiro compreende que o juiz é um homem moderno, que não pauta sua conduta de acordo com a cordialidade do Brasil arcaico. Por fim, entre arcaico e moderno, talvez o mineiro tampouco entenda o moderno mecanismo econômico que fomenta e conduz a voracidade por terra que o italiano demonstra, numa lógica que faz com que "um palmo de terra" seja objeto de demanda judicial.

No italiano ela se mostra quando esse, ao acaipirar-se, "regride culturalmente" (CANDIDO, 2001) e passa a operar de acordo com as visões e valores de sua nova pátria, um lugar (aparentemente) menos moderno que seu país de origem.

No juiz e no advogado - que possuem, pé esquerdo na burocracia moderna letrada e institucionalizada, pé direito no sistema patriarcal arcaico e regente das relações mais 
estruturantes de um "mundo cordial" 81 - está expressa também a convivência coexistente do arcaico com o moderno. Aqui, os elementos da narrativa reforçam a noção de uma realidade sociológica em que a polarização entre o arcaico e o moderno traz à tona conflitos, incongruências, antagonismos e desajustes. Expressões de um país em que o processo histórico não caminhou na direção de estabelecer a modernidade por completo; lugar onde este "estar por completar-se" ainda hoje implica desigualdades, privilégios, distorções sociais e econômicas, patriarcalismos.

A partir disso tudo é que a narrativa da canção em questão é construída de modo a nos fazer crer que o mineiro, sem dúvida, perderá a causa. Como membro de uma sociedade em que os interesses pessoais são contemplados via aparelhamento e uso privado das instituições governamentais, numa estrutura burocrática onde as decisões são tomadas a partir de interesses que convém às classes que compõem essa mesma elite, não é difícil perceber (nem estranho admitir) que o mineiro, pobre, posseiro e sem padrinhos, por certo sairia derrotado.

Pois dentro da lógica desse mundo de tempos sobrepostos, no qual aquilo que é consuetudinário está justaposto ao ordenamento jurídico moderno, mesmo quando a balança pesa para o lado da burocracia institucionalizada, as chances dos indivíduos identificáveis no personagem-tipo do mineiro terem seus interesses e direitos garantidos continuam ínfimas.

Assim o é porque, apesar da demanda estar sendo julgada e decidida via Tribunal, que o mineiro tenha um advogado para orientá-lo e defendê-lo, que o juiz seja ilibado e incorruptível, como referido acima, nesse mundo ao qual o mineiro pertence, os cargos com poder decisório e de mando estão concentrados, todos, ou nas mãos de cidadãos provenientes das elites ou de correligionários seus. E, no universo ao qual se reporta a canção, as decisões, via de regra, se coadunavam aos interesses dessa elite.

Daí o peso do juiz ser apresentado e confirmado como um homem moderno, não cordial. Donde esse fato contribuir não só para fazer o elogio à elite paulista quatrocentona como também para definir um rumo diferente ao destino do mineiro.

É por meio da parcela de modernidade que o juiz encarna que, mesmo lançando mão à esperteza de uma trapaça, ao ganhar a demanda, o mineiro "desfruta o momento fugaz de ser um cidadão" (SANT'ANNA, 2009, p. 334).

O potencial estético, o poder emancipatório, a graça e o humor dessa moda de viola estão, portanto, e também, tanto no improvável resultado da demanda e na suspensão do lugar-comum, quanto na subversão da ordem que ela nos anuncia ao seu final.

\footnotetext{
${ }^{81}$ Adapto o conceito de "homem cordial" (HOLANDA, 1995) aos meus propósitos.
} 
O risível é, no mais das vezes, receptáculo das verdades e idiossincrasias mais enraizadas, estruturais e condicionantes. 


\subsection{A questão do humor}

O tempo reservado ao lazer, conforme escreveu Antonio Candido, é característica essencial do modo de vida caipira. E o lazer, se não implica necessariamente a presença viva do humor e do riso, com certeza os sugere, sendo para ambos, campo fértil.

Para o caipira, o tempo do lazer é a hora de ouvir a viola, de jogar conversa fora com os vizinhos e parentes, da "contação de causos" e anedotas. De rir e se divertir, enfim.

Conforme apontaram Elias Thomé Saliba (SALIBA, 2002) e Camila Koshiba Gonçalves (GONÇALVES, 2013), o humor, na cultura e na música dos caipiras, é uma característica não só marcante como presente em todas as suas fases, constituindo-se, dessa forma, como um dos aspectos mais recorrentes dentro do modo de vida e do repertório caipiras.

Já as primeiras gravações feitas em São Paulo, ainda na era mecânica, foram classificadas pela imprensa da época como "de caráter cômico" e "humorístico" (GONÇALVES, 2013, p. 241). Em seu início, a "apresentação do caipira ingênuo, simples e atrapalhado, [foi] uma ideia que deu certo na capital paulistana, vendendo discos e livros que a ele se referiam" (GONÇALVES, 2013, p. 239).

Com o advento das gravações elétricas, porém, principalmente a partir de Cornélio Pires, o humor na música e na cultura caipira passou a ilustrar "o lado astuto, divertido e simples do caipira paulista" (GONÇALVES, 2013, p. 243). Assim, a partir da tradição iniciada em Cornélio Pires, retratar o caipira como um sujeito "cheio de espertezas, simplicidade e finura, capaz de façanhas e de se sobrepor às injustiças e ao enfautamento dos citadinos, com ricas peculiaridades" passou a ser o padrão (GONÇALVES, 2013, p. 297).

Em "O mineiro e o italiano", a comicidade é construída e o riso alcançado, justamente, de acordo com boa parte dessas características do humor corneliano, que, historicamente, se estabeleceu como padrão dentro da tradição da música e da cultura dos caipiras.

Trabalhando a partir da astúcia como um traço definidor do caráter de um dos personagens, Teddy Vieira e Nelson Gomes criaram uma história que ao seu final deixa a imagem de um caipira humilde - em oposição ao sarcástico e arrogante italiano. Esperto, o mineiro, por meio de um plano que é simples, mas cheio de "finura", é também capaz de uma façanha que o livra de uma (provável) injustiça. Nesse sentido 
funcionalidade e o cerne aventuresco do personagem Pedro Malazarte de antiga tradição ibérica. São as 'más artes' daquele que atazanam e infernizam os poderosos. Este personagem-tipo carrega uma lastro de picardia. (SANT'ANNA, 2009, p. 336)

Segundo Câmara Cascudo, há nele [Malazarte] igualmente o plano social de crítica, de ataque, de castigo aos ricos e aos fidalgos, adaptado no sertão brasileiro, aos fazendeiros e comerciantes que são ludibriados..." (CASCUDO, apud SANT’ANNA, 2009, p. 337). Bérgson apontou, igualmente, para esse caráter de crítica social que o humor comporta. Para o autor, é inerente ao riso a função social "de expor a vivência social, seus comportamentos, práticas e revezes" (BÉRGSON, apud MANOEL, 2016, p. 83). Pois é assim que, digno de um Pedro Malazarte, o mineiro sai, por fim, vitorioso, subvertendo o "caráter inelástico da estrutura de poder" (COHN apud FAORO, 2012, p. 8).

De mais a mais, "claro está que os valores simbólicos [dessa moda de viola] aplicamse a outras situações análogos, nas pelejas contra a injustiça e aos poderes constituídos, na mundividência do caipira” (SANT'ANNA, 2009, p. 330), pois

a arquitetura anedótica" desta moda de viola "dá ao personagem caipira um sentido de supremacia anti-heroica, mas resignada, ou admitida emotivamente como legítima. [...] Isso se deve, dum lado, pela ênfase à humildade; de outro, pela insurreição do humilde na luta contra os fundamentos sociais do poder político, movido pelo poder da astúcia. (SANT'ANNA, 2009, p. 322)

No cancioneiro da música caipira, essa função de crítica social e caráter de denúncia que o humor traz em si podem ser observados como uma constante. Dentro do repertório de Tião Carreiro e Pardinho, por exemplo, é possível se notar essa acepção do humor sendo empregada para "narrar os modos de vida e a identidade caipira" (MANOEL, 2016, p. 84). Ou seja, desde muito cedo, e através de sua história na fonografia, o humor fez-se presente como característica essencial não só das gravações de música caipira como também para a construção da carreira da dupla que interpreta o fonograma que serve de objeto de estudo a esta dissertação. Em outras palavras, a presença do humor faz parte da tradição dessa música e dessa dupla. 


\subsection{Aspectos musicais de "O mineiro e o italiano": quando a música informa tanto quanto a letra}

Intimamente ligada "ao fazer e ao viver do camponês do centro-sudeste do Brasil" (VILELA, 2015, p. 77), a música caipira, por meio de seus elementos musicais, ainda que de forma mais subjetiva do que o texto - mas não por isso menos reveladora -, também sugere a excelente síntese que vem sendo discutida ao longo deste capítulo.

Sem embargo, a maneira como "O mineiro e o italiano" foi composta, interpretada e gravada, em outros termos, sua narrativa musical, demonstra poder evocativo análogo ao de seu texto. A audição atenta de seu fonograma e a análise minuciosa de seus elementos musicais (sonoridades, instrumentação, arranjo, forma, melodia, ritmo, harmonia, prosódia), demonstram que o potencial sugestivo aí presentes são tão fortes quanto os manifestos na letra. Desse modo, assim como o escrutínio de sua letra, a análise musical também suscita questões inerentes ao modo de vida caipira, à história de sua gente e às relações entre estes e o mundo à sua volta.

Lançada por Tião Carreiro e Pardinho em 1964, primeiro em disco 78 rpm e logo em seguida no LP "Linha de Frente”, sua instrumentação é mínima: viola caipira e duas vozes masculinas. O arranjo, simples e direto: introdução, cinco estrofes que repetem a mesma melodia - cantada (majoritariamente) em duetos de terça -, um mesmo recortado de viola caipira que se repete por cinco vezes e um coda que, ao final da última estrofe, recupera a mesma frase tocada nos três últimos tempos do compasso final do recortado.

Assim, logo de início os elementos estruturais desse fonograma nos remetem ou fazem pensar nos "mínimos sociais", na rusticidade crua, na cultura da solidariedade descritas como essenciais na definição do caipira e de sua cultura. Seria pois, a música caipira, uma música de mínimos vitais?

Diferentes autores atestam que, no que se refere às suas propriedades formais e harmônicas, a música caipira caracteriza-se por ser simples, homogênea. João Paulo do Amaral Pinto escreve que "os gêneros caipiras e sertanejos de maneira geral, costumam ser relativamente simples em suas progressões de acordes, bem como em sua forma" (PINTO, 2008, p. 147). Roberto Corrêa, no mesmo sentido, afirma que

a estrutura musical das canções das duplas é, basicamente, a mesma: introdução e parte $\mathrm{A}$, que se repetem de acordo com o tamanho da poesia. Em alguns casos, é acrescentado um refrão. (CORRÊA, 2000, p.70) 
A harmonia é simples, e grande parte das músicas utiliza-se de uma tonalidade maior, centrada nos acordes de Tônica, Sétima da Dominante, e Subdominante. (CORRÊA, 2000, p.70)

Sendo a música de viola uma parte fundamental do modo de ser do caipira e, consenso, que "a música caipira de raiz não existe sem a viola caipira" (SETUBAL, 2005, p. 126), o emprego deste instrumento no arranjo nos remete diretamente a um dos elementos centrais da vida do caipira. Para além disso, a presença solitária da viola caipira na gravação pode sugerir a ideia de isolamento, que, como apontado anteriormente, é característica marcante da cultura caipira. Ainda sobre questões que concernem à instrumentação, a ausência do violão também aponta para um elemento que remete diretamente à experiência e cultura caipira: é que, para os caipiras, o violão era "instrumento da cidade", não da zona rural (GONÇALVES, 2013, p. 269).

Por outro lado, o "estar sozinho" do caipira nunca significou estar completamente isolado. Seu isolamento se caracterizava por ser um isolamento relativo, e tinha na família e nos vizinhos de bairro uma presença tão real quanto necessária (CANDIDO, 2007). À vista disso, esse isolamento, que é apenas relativo, está representado, na moda de viola, pelo canto em dueto: o cantar em dupla pressupõe parceria, ajuda, colaboração, convívio e auxílio vicinal. Assim, ao mesmo tempo em que esse fato faz alusão às "raízes da cultura caipira embasadas [nos] laços de vizinhança e na reciprocidade" (SETUBAL, 2005, p. 101), alude a uma dinâmica convencional do mutirão. Do mesmo modo que no mutirão as pessoas se reúnem com um propósito específico, que tem data e tempo de duração mais ou menos previstos para acontecer e durar (CANDIDO, 2007), o ato de cantar em dupla também se realiza com data e duração previstas e geralmente no âmbito de festas ou ocasiões especiais. Ademais, a prática do mutirão previa, ao seu final, a realização de uma festa. Ora, o lazer e a música, elementos igualmente fundamentais para a cultura caipira, têm suas origens “totalmente vinculada às festas" (SETUBAL, 2005, p. 126).

Uma outra característica da cultura caipira que este fonograma evoca: cantadas na maior parte do tempo em intervalos de terça, a voz de Pardinho se caracteriza justamente por seu tom nasal e agudo, típicos do falar e do cantar caipira, conforme estudou Mário de Andrade. "Dada a simplicidade no acompanhamento e o predomínio completo da melodia e do canto sobre a instrumentação, Mário de Andrade acabou por enfocar suas análises na fala dos cantores". E, ao assim fazer, o que mais chamou sua atenção foi o aspecto nasal da fala caipira, que para ele se manifestava especialmente no canto (GONÇALVES, 2013, p. 267). 
Assim como sua instrumentação e arranjo, a harmonia de "O mineiro e o italiano" é simples. Construída sob as relações e funções harmônicas mais básicas, por meio dos movimentos de tônica - dominante - tônica e tônica - subdominante - tônica, a harmonia desta moda de viola está estruturada a partir dos coeficientes mínimos exigidos para se estabelecer a tonalidade, como explica Sérgio de Freitas. Segundo esse autor, ao lado do movimento tônica - subdominante - dominante - tônica, os dois formatos de progressão que compõem a harmonia de "O mineiro e o italiano", "são as mais simples relações harmônicas existentes na tonalidade, são os resumos mínimos do sistema, são aquelas menores articulações funcionais capazes de estabelecer a tonalidade" (FREITAS, 1995, p. 23-24). Qualquer estrutura mais básica do que estas significa ausência de relações tonais.

Antonio Candido escreveu que a um "mínimo vital" equivale um "mínimo social" (Candido, 2017, p. 89), definindo esses conceitos como o resumo dos níveis mínimos de recursos, funções e articulações para que um sistema alimentar e social seja capaz de existir e/ou se estabelecer. Qualquer nível abaixo desses mínimos significaria, segundo o autor, anomia ou extinção. Se for válida a ideia de que o mínimo harmônico - representado pela estrutura da harmonia de "O mineiro e o italiano" - pode ser interpretado como equivalente aos mínimos vitais e sociais observados por Candido, novamente aqui há uma correspondência entre um elemento musical desta moda de viola com um estrutural da cultura caipira.

Somado a isso, os aspectos harmônicos do fonograma sugerem uma outra característica basilar da cultura caipira. $\mathrm{Na}$ Paulistânia, configurou-se, como visto anteriormente, um tipo de cultura e vida social "condicionados em grande parte por aquele fenômeno de mobilidade" (CANDIDO, 2017, p. 43). Assim, a mobilidade pode ser entendida como uma das características mais essenciais e primárias do caipira e sua cultura.

Ora, na música, uma das funções da harmonia é possibilitar/provocar/promover a sensação de movimento, de um deslocar-se. E, musicalmente falando, o que possibilita essa sensação de deslocamento é o movimento harmônico gerado pelo caminhar de um acorde a outro, de uma função harmônica a outra. É por meio das relações funcionais tonais, e do trânsito entre elas, que a tonalidade se viabiliza e se estabelece. E é exatamente por meio desses movimentos e suas relações que, ao se concretizarem, são geradas as harmonias que sugerem a sensação auditiva do movimento.

Tal qual o caipira que se desloca em busca de terra nova para plantar e existir, e que, mesmo em seu isolamento e simplicidade de mínimos, para garantir sua subsistência necessita dos familiares e vizinhos, os acordes buscam nas funções tonais, nos acordes que 
por meio delas se avizinham, sua razão de ser e existir; e, nesse deslocar-se constante de um acorde ao outro, por meio das relações tonais encontram os meio para dar vida à tonalidade que, por sua vez, gera a harmonia que garante o movimento.

Em termos de forma e estruturação musical, no fonograma gravado por Tião Carreiro e Pardinho em 1964, as cinco estrofes são precedidas pela introdução e interpoladas pelo já citado recortado de viola caipira que, aparecendo - ao mesmo tempo - sempre antes e depois de cada estrofe (à exceção da última), cumpre a dupla e cíclica função de: 1) preparar a atenção do ouvinte para o texto que virá; 2) dar tempo para que este apreenda o que acabou de ser narrado.

A introdução caracteriza-se por ser um trecho modal, construído sobre um compasso binário e baseado no modo mixolídio do campo harmônico maior. Tendo como fundamental a nota $\mathrm{Si}$, o trecho é estruturado por meio de um baixo pedal.

Sobre o baixo pedal e sua utilização por Tião Carreiro, ao analisar a introdução do Pagode de Viola "Nove Nove" - igualmente gravada por este violeiro -, João Paulo do Amaral Pinto escreveu:

também é muito frequente o uso dos pares mais graves soltos, como o quarto e quinto par. Assim como as outras cordas soltas, eles funcionam muitas vezes como preenchimento da melodia, formando por vezes baixos pedais, devido ao padrão rítmico fixo determinado pelo arpejo da mão direita. (PINTO, 2008, p. 151)

A citação acima descreve o caso, também, das introduções de viola tocadas por Tião Carreiro em "Pagode em Brasília" (PINTO, 2008, p. 151) e em "O mineiro e o italiano", conforme demonstra a transcrição a seguir: 


\section{O mineiro e o italiano}
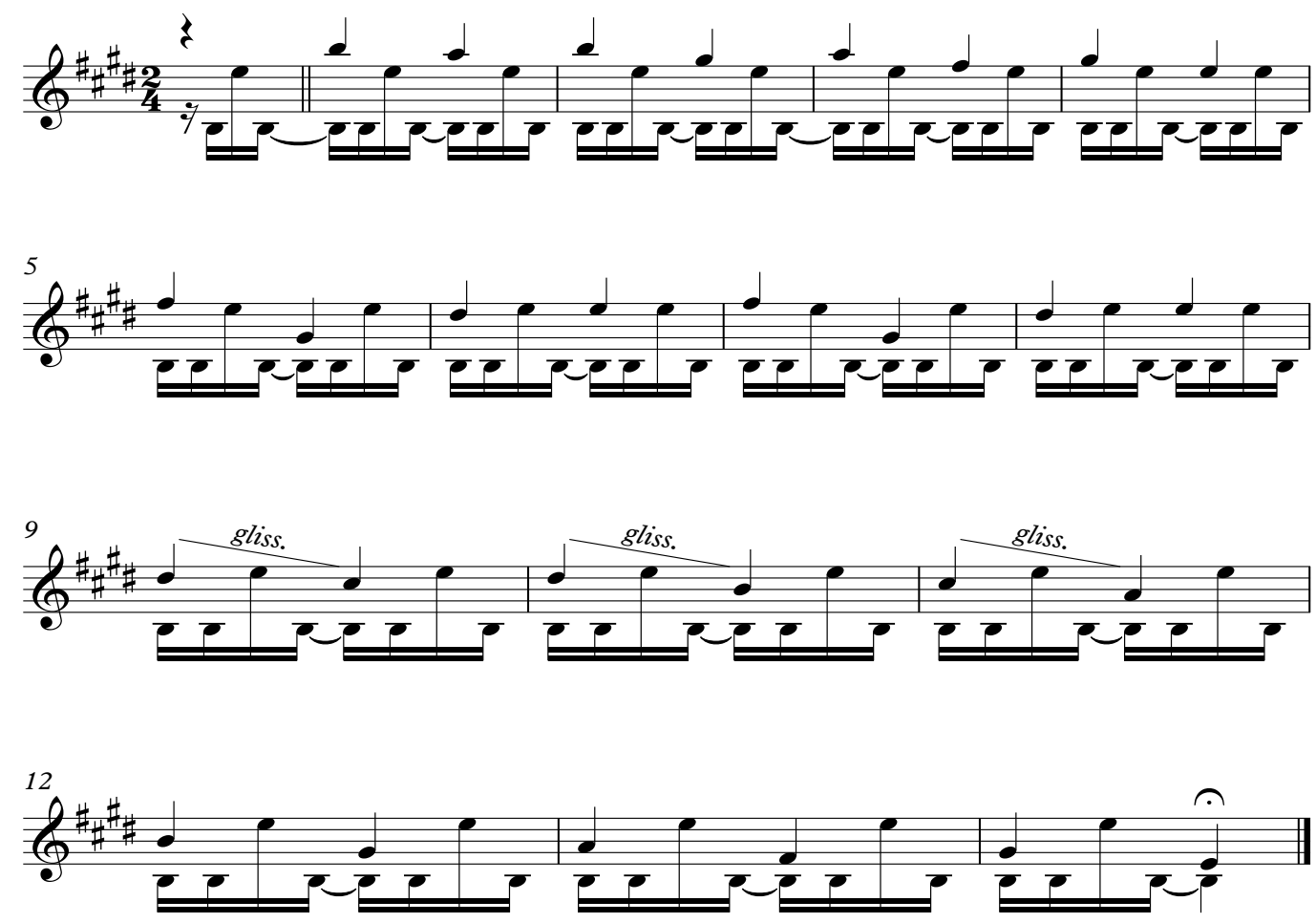

Ritmicamente organizado em torno de sucessivas semicolcheias, nesse baixo pedal o violeiro ponteia a quarta justa do modo mixolídio (nota $\mathrm{Mi}$ ) a cada três repetições de sua fundamental (nota $\mathrm{Si}$ ). Essas notas pedais "no grave e no agudo", além do significativo "papel rítmico" que desempenham, "causam um efeito harmônico modal" (PINTO, 2008, p. 151), formando uma espécie de base que sustenta a voz descrita pelas semínimas, responsável pelo contorno da melodia. Do efeito gerado pela sobreposição destas duas estruturas caracterizam-se a sonoridade do modo mixolídio e a respectiva sensação auditiva que este transmite.

Uma pergunta plausível em relação ao aspecto harmônico desta introdução pode ser a que indague se este Si, sendo o quinto grau da escala de Mi maior, não cumpriria, na verdade e neste exemplo, o papel de dominante do acorde de tônica, que nesta composição é o acorde de $\mathrm{Mi}$ maior ${ }^{82}$ - acorde que é tocado imediatamente após os quatorze compassos que

\footnotetext{
${ }^{82} \mathrm{Na}$ gravação, ouve-se a tonalidade de Mi bemol e não a de Mi. Este fato pode estar relacionado tanto a questões técnicas da gravação quanto àquelas que envolvem a afinação da viola caipira, tema amplo, com
} 
compõem a introdução. Aproveita-se o ensejo desse detalhe para abrir-se um parêntese e chamar a atenção para a irregularidade da quadratura desta introdução. Construída sob quatorze compassos, ela apresenta uma dimensão que, musicalmente, não é comum. $\mathrm{Na}$ forma popular da canção, quadraturas com tamanhos expressos em múltiplos de quatro $(4,8$, $12,16,32)$ são mais correntes, como comprovam a prática musical e o repertório da música popular de diferentes culturas e tempos históricos ${ }^{83}$.

Voltando à possível questão sobre o Si exercer a função harmônica de dominante ao invés de estabelecer-se como centro modal, pelas razões apontadas no parágrafo anterior, acredito que a resposta seja não. Para além do que já foi dito, o fato de não haver movimento harmônico por quatorze compassos também nos remete às noções de homogeneidade e linearidade harmônica, características da música modal. Por fim, os efeitos acústicos gerados pela utilização do baixo pedal nos fazem ouvir e perceber os seis compassos do recortado de viola que se segue à introdução não como uma continuação ou segunda parte desta, mas como um novo evento musical, uma nova estrutura. $\mathrm{O}$ fato do recortado ser repetido sempre ao começo e ao final de cada estrofe também acentua sua compreensão auditiva enquanto uma parte descolada da introdução, como um evento musical que se refere mais à dinâmica das estrofes do que à da própria introdução.

No que se refere ao modo mixolídio e seu emprego na música caipira, é novamente João Paulo do Amaral Pinto que nos serve de base. Segundo o autor,

este modo é pouco frequente nas músicas do segmento caipira e sertanejo ao menos até a década de cinquenta e, como se sabe, é mais comum na música regional nordestina, além de ocorrer em manifestações populares da região do norte de Minas Gerais. Segundo o que o violeiro e pesquisador Ivan Vilela nos relatou, a utilização do modo mixolídio por Tião Carreiro em suas composições colaborou decisivamente para a inserção deste estilo de

diversas particularidades e nuances. As questões que concernem tanto às afinações da viola caipira quanto às causas de sua variabilidade e instabilidade foram estudadas a fundo por Ivan Vilela e estão muito bem descritas em um dos itens do capítulo I de seu livro Cantando a própria história: música caipira e enraizamento. Para este trabalho, é suficiente saber-se que um dos fatores que causavam pequenas variações na afinação - como esta de meio tom observada na gravação que nos serve de base - estão ligados, dentre outras coisas, ao fato dos violeiros afinarem de ouvido, sabendo de core, mais ou menos, a tensão que deveria ser aplica às cordas para que as mesmas atingissem determinado tom (sendo os mais comuns os de Mi e Ré). Dessa forma, às vezes "errava-se" o grau de tensão, um pouco para cima ou um pouco para baixo. Isto posto, por razões práticas todas as transcrições e referências à tonalidade do fonograma analisado por este trabalho serão realizadas e referidas como estando na tonalidade de Mi.

${ }^{83}$ Sobre esta afirmação, analise-se (e conte-se os compassos) da grande maioria das canções do repertório da música popular, tanto brasileira quanto de outros países (EUA, por exemplo). O acesso a qualquer coletânea de canções comprova facilmente esta afirmação. 
melodia e harmonia no segmento sertanejo. (PINTO, 2008, p. 140-141)

É pois, sob o contexto da inserção do modo mixolídio na linguagem e práxis da música caipira que, segundo Amaral Pinto, podemos observar que a partir da "gravação em 1961 do pagode 'Nove Nove' [...] (o primeiro pagode a incluir o mixolídio), Tião Carreiro iria compor uma série de outros pagodes, introduções e músicas com esse modo" (PINTO, 2008, p. 140-141). Dessa forma, a partir da legitimidade, da importância e da posição ocupada por Tião Carreiro dentro do universo da música caipira ${ }^{84}$, este não só inaugurou o emprego deste modo exógeno aos gêneros caipiras como também o validou e consolidou, tornando-o parte integrante da linguagem e do discurso musical caipira. Isso se deu, como recém afirmado, por meio de composições ou introduções, tal qual a de "O Mineiro e o Italiano", que ficaram célebres e baseavam-se no uso do modo em questão.

Ainda sobre esta introdução de "O mineiro e o italiano", cabe destacar, por fim, que ela se enquadra numa prática musical que é conhecida por ponteio ou ponteado. Consoante o que afirma Rafael Marin da Silva Garcia,

em algumas músicas a viola caipira antecede o canto da dupla e a introdução harmônica, representada pelo "recortado", com uma linha musical essencialmente melódica [,] de caráter virtuosístico [e] não relacionada com a melodia na qual será cantado o texto. Temos, portanto, que além do acompanhamento do dueto vocal com as escalas duetadas, ou deixando os cantadores à capela, a viola caipira também pode realizar aquilo que geralmente os violeiros designam de "ponteio" ou "ponteado", que difere do "recortado" por ser mais melódico do que rítmico. (GARCIA, 2011, p. 192)

Não somente o ponteado da introdução de "O mineiro e o italiano" como também a estrutura de seu arranjo e sua forma encerram o conteúdo descrito neste excerto. A citação inventaria, quase que como uma caracterização pormenorizada, todos os elementos e estruturas musicais que dão forma e conteúdo musical ao fonograma que nos serve de objeto de estudo. Ficam de fora, apenas, a coda e a função do recortado quando tocado com a finalidade de, ao mesmo tempo, arrematar uma estrofe e preparar o início da próxima.

Em acordo com e exemplificando os elementos e características levantados por Rafael Marin da Silva Garcia, a versão de Tião Carreiro e Pardinho para "O mineiro e o italiano"

\footnotetext{
${ }^{84}$ Sobre a legitimidade, a importância e a posição ocupada por Tião Carreiro dentro da música e para a cultura caipiras ver PINTO, 2008.
} 
contém um ponteado que apresenta uma melodia diferente daquela das estrofes e que, antecedendo o recortado e em comparação a ele, é essencialmente mais melódico do que rítmico. Recortado esse que, no arranjo da canção cumpre, também, a função de introdução harmônica para o canto da dupla. Cantada em dueto de terças (com algumas passagens em quartas), a melodia das estrofes desta moda não possui acompanhamento harmônico. É por vezes acompanhada pela viola caipira (que faz a dobra da primeira voz em uníssono, fazendo uso da escala duetada ${ }^{85}$ ) e, por outras, realizada à capela.

Como anteriormente mencionado, logo em seguida à introdução é tocado, pela primeira de suas cinco repetições, um recortado de viola. $\mathrm{O}$ recortado que se ouve entre as estrofes é o mesmo daquele que procede a introdução, com uma sutil diferença em seu final, observada nos dois tempos do último compasso. Naquele recortado executado imediatamente após a introdução, há, em seus dois últimos tempos, um movimento harmônico de tônica dominante - tônica. Movimento que não é realizado nas outras quatro ocasiões onde se ouve o recortado. Nelas, a finalização se dá por meio de um acorde de tônica que preenche os dois tempos do último compasso.

Todos os recortados do fonograma são, invariavelmente, iniciados pela frase em anacruse $^{86}$ abaixo transcrita:

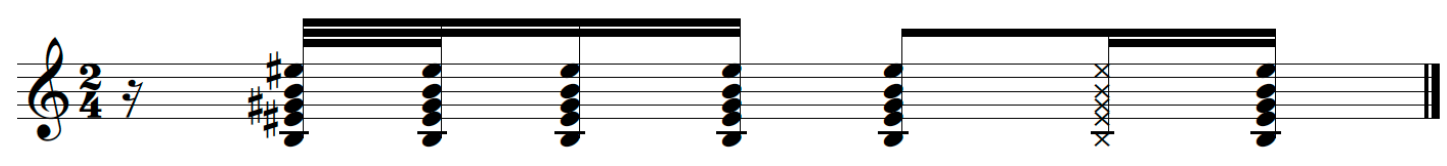

De igual modo, todos são concluídos por uma fermata aplicada sobre seu acorde final. Em todos os casos essa fermata funciona como um recurso que dilui o tempo do compasso, propiciando ao intérprete-cantor dar início à melodia da estrofe sob outra lógica temporal que não a do compasso.

Antes de seguir-se adiante, a esta altura cabe ainda um comentário sobre a quadratura destes recortados. Os quatro recortados interpolados entre as estrofes possuem a dimensão de

\footnotetext{
${ }^{85}$ Sobre o conceito de escala duetada ver PINTO, 2008.

${ }^{86}$ Esta frase em anacruse é também conhecida pela termo rasqueado anacruse (PINTO, 2008, p. 92).
} 
quatro compassos. No que vem logo a seguir da introdução, porém, contam-se cinco compassos, sendo a fermata realizada no segundo tempo do quinto compasso.

Um outro aspecto que chama a atenção em relação à execução deste recortado inaugural é que, em temos de métrica temporal, seu início, na gravação, é um pouco “atropelado". É muito difícil contar-se os tempos ou perceber a continuidade métricatemporal que o liga à ou que dê sentido rítmico reconhecível e condizente com a métrica do compasso da introdução. Dito de outra forma, a continuidade rítmico-temporal é quebrada, perde-se a natural e fluida passagem de uma seção à outra, parecendo que as duas estruturas foram coladas uma à outra - de maneira ou desatenta ou que ignorou a métrica e os tempos de seu de seu compasso, que é binário tanto na introdução quanto no recortado. Tem-se a impressão, por vezes, que ao invés de tocadas e gravadas ao vivo e em sequência, essas partes foram gravadas em separado, editadas e posteriormente colocadas uma em prossecução à outra. $\mathrm{Ou}$ isso ou esse fato atende a regras e procedimentos estruturais e estilísticos inerentes à forma moda de viola os quais não me foi possível averiguar ou perceber.

Há portanto, na passagem de uma estrutura à outra, uma lacuna, uma quebra temporal que, pelo que foi descrito até aqui, pode ser tributária a uma série de potenciais fatores musicais e/ou técnicos. Acredito que esse fato pode estar ligado, como cogitado acima, tanto a problemas técnicos de estúdio (i.e. corte da fita de gravação para se fazer a edição do trecho musical ou uma emenda, pouco tempo de estúdio - que, numa situação de gravação é sempre o fator mais caro e escasso) ou a questões técnico-interpretativas-formais. Até o momento em que escrevia este texto, não havia logrado entender ou encontrar alguma fonte que comprovasse um desses potenciais fatores como causa da ruptura temporal ou que explicasse de forma satisfatória esse evento musical e suas possíveis razões de ser. De igual forma, não fui capaz de compreender musicalmente o trecho e transcrevê-lo a fim de poder aferir alguma conclusão pela via da análise do documento em si.

A propósito do recortado enquanto estrutura musical própria à música caipira, e, mais especificamente à forma moda de viola, é possível afirmar que, de início, recortado e moda de viola eram termos que se referiam a duas situações distintas ${ }^{87}$, mas pertencentes a uma mesma prática. Dentro do universo da cultura caipira, essas duas expressões musicais eram

\footnotetext{
${ }^{87}$ É somente "com o advento do disco [que], tanto a moda de viola quanto o recortado passaram a ser gêneros também executados separadamente da catira como um todo" (PINTO, 2008, p. 91).
} 
partes integrantes da (do) catira, uma manifestação folclórica que envolvia dança, música e a narração de histórias e "causos satíricos" $"$. Como explica João Paulo do Amaral Pinto,

a catira ou o catira é um gênero caipira [...] que envolve dança, canto e toque de viola e é encontrado nos estados de São Paulo, Minas Gerais e Goiás. Realizada por duas filas de dançadores e por uma dupla de cantadores, a catira alterna momentos de dança e de moda de viola. (PINTO, 2008, p. 90)

No momento da dança, os violeiros não cantam, apenas tocam a batida da catira na viola para acompanhar os sapateados e palmas dos dançadores. Enquanto estes descansam, os violeiros cantam modas de viola [...]. (PINTO, 2008, p. 90 - grifo meu)

Não é demais reafirmar que a forma moda de viola, enquanto gênero musical, caracteriza-se - desde seu princípio, quando ainda ligada à catira, até sua aparição em disco por ser uma manifestação que sofreu poucas alterações em sua estrutura e formato ${ }^{89}$.

Vejamos a transcrição da batida tradicional da catira, proposta por Amaral Pinto (PINTO, 2008, p. 92):

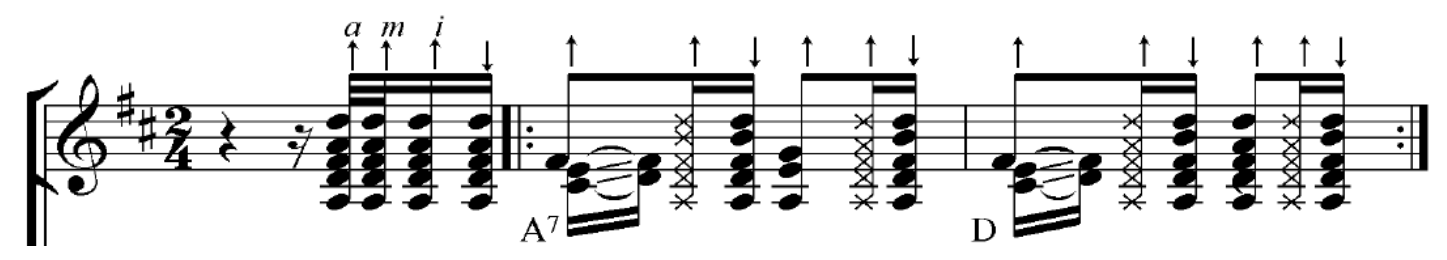

Agora comparemos a batida acima com a que se segue (PINTO, 2008, p. 92):

\footnotetext{
${ }^{88}$ SANT’ANNA, 2000.

${ }^{89}$ Uma das alterações sofridas pela moda de viola, que vale a citação, foi a adaptação de sua narrativa (Romance) ao formato-tempo da indústria fonográfica. É bem conhecida, documentada e citada (VILELA, 2015; SANT'ANNA, 2000) a passagem em que Tonico e Tinoco explicam a diminuição da duração temporal das narrativas das modas quando estas passaram a ser gravadas pela indústria do disco.
} 


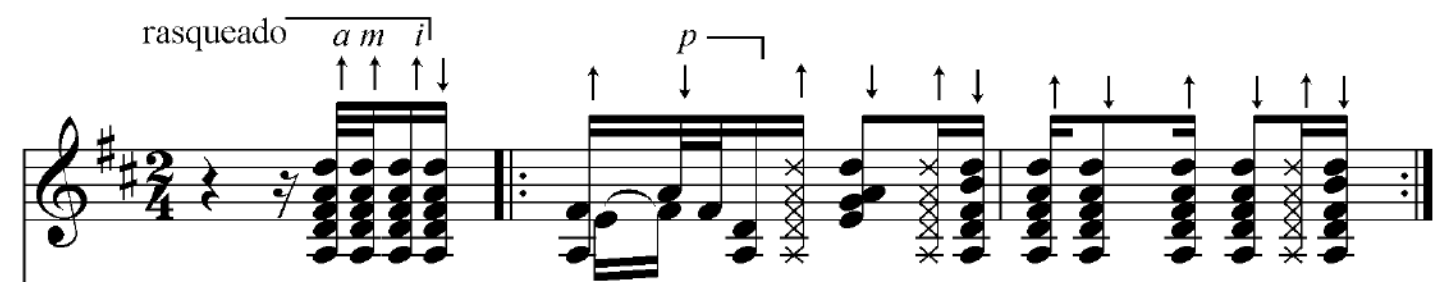

Essa segunda batida nada mais é do que a síntese da batida do recortado de Tião Carreiro $^{90}$. Note a semelhança entre as duas que, de fato, diferem em apenas uma figura rítmica: a do primeiro tempo do segundo compasso.

Assim, pelo que foi exposto nos parágrafos precedentes em relação ao recortado, depreende-se que este, ao mesmo tempo em que era parte integrante da moda de viola, existia independente dela, como acompanhamento rítmico-musical à dança da catira pois, como descrito acima, essa dança era acompanhada por um ritmo repicado que nada mais era do que o ritmo produzido por meio da batida da catira. Para além disso, esse ritmo repicado entrou para o vocabulário (e prática) da música caipira como aquele que dava forma rítmica a um trecho que aceitava como sinônimo os termos repique, repicado, recorte ou recortado. Tendo isso em conta - e considerando a confusão e miscelânea de usos, significados e significações que os termos em questão sofreram e/ou assumiram ao longo do tempo -, acredito que esses termos se referem a estruturas musicais intercambiáveis. Eles acabam por nomear, de forma plural, fenômenos que musicalmente são, senão idênticos, ao menos equivalentes.

De igual modo, é seguro afirmar que o recortado de Tião Carreiro nada mais é do que uma variação da batida da catira. Mas com um detalhe importante: a incorporação de um síncopa! As questões que envolvem as relações da síncopa com a música caipira, bem como aquelas que discutem a presença (ou não) de elementos afro-brasileiros neste segmento musical, são questões que extrapolam os limites e objetivos deste trabalho.

\footnotetext{
${ }^{90} \mathrm{O}$ recortado de viola tocado por Tião Carreiro no fonograma de "O mineiro e o italiano" se não é idêntico, é deveras semelhante ao desta síntese oferecida por João Paulo do Amaral Pinto.
} 
Em sua obra $O$ Dialeto Caipira, Amadeu Amaral afirma que “ [...] a prosódia caipira [...] difere essencialmente da portuguesa [sendo que] o tom geral do [seu] frasear é lento, plano e igual [...], [e], as pausas [...], são [...] mais abundantes" (AMARAL, 1920, p. 17). Na moda de viola "O mineiro e o italiano" essa prosódia peculiar está representada mormente pela estrutura da melodia e pela forma como as palavras são entoadas e pronunciadas pela dupla Tião Carreiro e Pardinho. Esse fato pode ser observado por meio de alguns elementos e características que conformam a melodia e sua interpretação.

Esse "pausar-se abundantemente" pode ser percebido nas fermatas longas que ocorrem em todos os finais de estrofe, sempre antes de cada recortado de viola. Se estas fermatas ao final de cada estrofe podem ser compreendidas, aqui, como representação das abundantes pausas do falar caipira, observadas por Amadeu Amaral ${ }^{91}$, o prolongamento da duração das notas da melodia ao final de cada frase pode ser interpretado como um reflexo do lento tom geral de frasear do caipira.

Nesta melodia as notas com maior duração de tempo situam-se, sempre, na última (caso da $1^{\mathrm{a}}$ estrofe) ou na penúltima (caso das $2^{\mathrm{a}}, 3^{\mathrm{a}}, 4^{\mathrm{a}}$ e $5^{\mathrm{a}}$ estrofes) sílaba tônica da derradeira palavra de cada frase. Ou seja, há, nesse demorar-se ao final de cada período, algo que remete a esta lentidão da fala, do fraseado, a uma ausência de pressa para se encadear o que vem a seguir, àquilo que se está por dizer. Dá-se ao ouvido e ao intelecto, assim, um tempo para se absorver e pensar no que foi enunciado, ao mesmo tempo em que se cria uma expectativa pela sequência do enredo.

Esse aspecto é reforçado pela estrutura musical-interpretativa da moda de viola que, pela razão mesma da letra (com sua história e mensagem) ocupar lugar central em sua forma, a melodia cantada raramente possuir acompanhamento harmônico. Como observa Romildo Sant'Anna, "as melodias da Moda Caipira e, principalmente das modas-de-viola, [...] abstêmse de significações propriamente musicais em respeito à inteligibilidade do texto" (SANT'ANNA, 2009, p. 140). Desta feita, na moda de viola, acompanhamento, quando há, é realizado pela viola caipira, de forma melódica, em uma situação em que o violeiro toca a melodia cantada ao mesmo tempo e no mesmo ritmo que o cantor a canta. Ainda sobre esse aspecto Romildo Sant'Anna escreve que “o acompanhamento instrumental" [na moda de viola] se evidencia no intervalo entre as estrofes, funcionando como elemento de suspense e

\footnotetext{
${ }^{91}$ AMARAL, 1920.

${ }^{92}$ Leia-se "harmônico-rítmico".
} 
anticlímax, despertando o interesse pelo porvir lírico-narrativo da estrofe seguinte" (SANT'ANNA, 2009, p. 73-74). É o que se observa no fonograma ora analisado.

Diferentemente das emboladas e desafios, típicos do nordeste brasileiro, por exemplo, a moda de viola não é cantada de forma rápida e contínua, sendo que seus versos e estrofes não obedecem a um encadeamento direto, sem interpolações instrumentais e/ou pausas (fermatas). Em acordo também com esta característica do gênero, em "O mineiro e o italiano" as palavras, as frases e as estrofes não são pronunciadas com velocidade e/ou encadeadas imediatamente umas às outras. Indo além e extrapolando esse único exemplo, de maneira geral - como observam autores tais quais Vilela (VILELA, 2015) e Sant'Anna (SANT'ANNA, 2009) -, salvo em algumas exceções, neste gênero da música caipira as palavras quase nunca são pronunciadas de forma corrida. Quando isso ocorre, serve tão somente ao propósito de adequar o tamanho de uma ou outra palavra ou frase ao da melodia, pois, como explica Ivan Vilela em seu livro Cantando a própria história: música caipira e enraizamento, na música caipira, "talvez pela não importância dada ao uso das regras de metrificação, algumas vezes os versos se fazem maiores que o tamanho da melodia que os comporta" (VILELA, 2015, p. 75). Ainda de acordo com Vilela, "a saída para lidar com esse aparente problema é um acelerar da fala que extrapola o esperado rítmico, criando assim um novo e sofisticado recurso, o da transgressão da normalidade prosódica" (VILELA, 2015, p. 75).

O professor-violeiro toma exatamente a moda "O mineiro e o italiano" como exemplo ilustrativo do argumento que desenvolve acerca das questões da métrica e da prosódia na música caipira. Tendo por base a primeira estrofe da letra o autor desenvolve uma análise da qual vale a transcrição:

O mineiro e o italiano (1)

viviam às barras dos tribunais (2)

Numa demanda de terra (3)

que não deixava os dois em paz (4)

Só de pensar na derrota (5)

o pobre caboclo não dormia mais (6)

O italiano roncava (7)

nem que eu gaste alguns capitais (8)

Quero ver esse mineiro (9)

voltar de a pé pra Minas Gerais (10) 
Notemos que os versos se alternam entre sete e nove sílabas. O verso de número seis tem onze sílabas em vez de nove, e o verso de número oito tem oito sílabas em vez de nove. Outro acontecimento interessante é que vez ou outra, ao cantar, não executam a esperada elisão de vogais. Separam-nas para dar a métrica, como é o caso dos versos de número quatro, que tem oito sílabas métricas em vez de nove (que-não-dei-xa-vaos-dois-em-paz) e se transforma, ao ser cantado, em nove sílabas métricas (que-não-dei-xa-va-osdois-em-paz) e o verso de número sete, com seis sílabas métricas (oi-ta-liano-ron-ca-va), que quando cantado passa a ter sete sílabas métricas (o-i-talia-no-ron-ca-va).

(VILELA, 2015, p. 75-76)

Ao cantar de uma maneira que não empreende a elisão das vogais, os intérpretes fazem com que o verso se torne maior do que realmente é, como demonstrado acima. Uma vez maior, alongado, esse verso não só se adéqua à quadratura da melodia como também demanda mais tempo para ser declamado (em relação ao anterior), como se pode supor. Se é válido que algo que demande mais tempo pode ser associado à ideia de "algo que é mais lento", pode-se inferir que o resultado desse processo de "alongamento do verso", tipificado pelo exemplo da primeira estrofe de "O mineiro e o italiano", ilustra e corrobora a noção de um mais lento e pausado falar do caipira.

Os aspectos plano e igual do frasear caipira estão sintetizados por uma melodia que é quase linear e pelo fato, observado por Sant'Anna, de que as melodias da música caipira, "principalmente das modas-de-viola, [serem] sempre muito semelhantes entre si" (SANT'ANNA, 2009, p. 140). Essa semelhança, que pode ser lida como "pouca diversidade" estético-expressiva ou ainda enquanto ausência de variação significativa em termos de forma, estrutura, quadratura, relações intervalares e escolha entre/das notas, tonalidades, alturas, movimentos melódicos de tessitura reduzida, pode ser interpretada de forma similar como índice de igualdade no sentido de configurar um tipo específico de discurso e maneira de falar que se caracterizam por terem um ritmo discursivo e uma prosódia mais uniformes e constantes em sua realização e entoação se comparados ao da língua portuguesa falada em outras regiões do Brasil (sob a influência formativa de outros dialetos e sotaques) ou mesmo em relação ao "Português de Portugal". Se esse argumento for válido, as melodias das modas 
de viola atuariam, a este respeito, na qualidade de espelho desta prosódia mais homogênea, regular, com pouca variação dinâmica ${ }^{93}$ no falar e cantar.

Ainda sobre os aspectos relativos à linearidade e à uniformidade da melodia de " $O$ mineiro e o italiano", é válido constatar-se que ela foi construída sob uma pequena variação nas alturas das notas e que, suas cinco diferentes frases, são as únicas utilizadas em todas as cinco estrofes da moda.
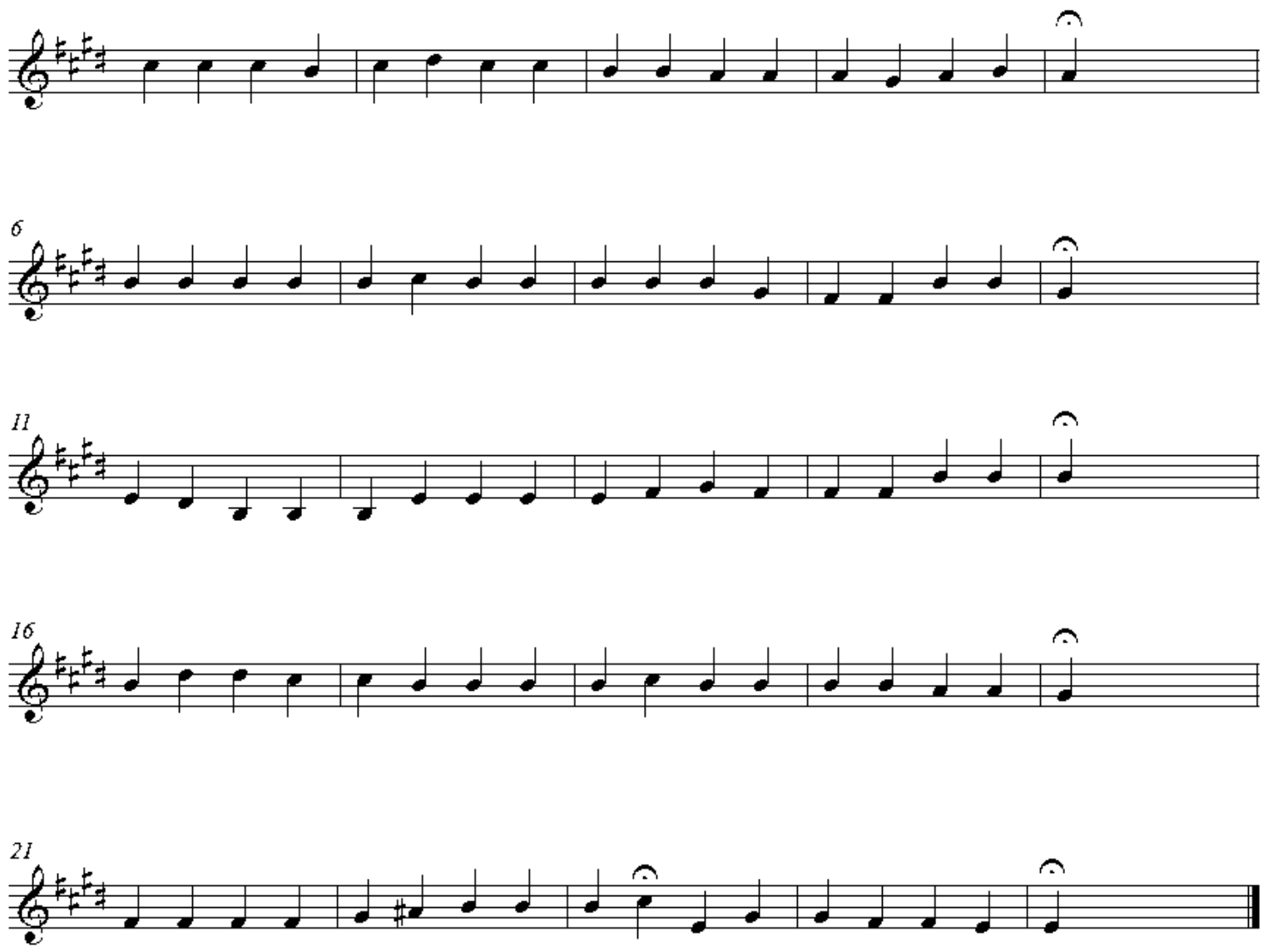

A transcrição acima refere-se à primeira voz, cantada na gravação por Tião Carreiro. Como se pode perceber, a melodia é composta majoritariamente por sequências de notas repetidas - o que remete diretamente à ideia de algo que é plano e igual -, por trechos em as notas se movem em graus conjuntos - o que se relaciona à noção de pouca variabilidade e de

\footnotetext{
${ }^{93}$ Dinâmica, nesse caso, na acepção musical do termo, qual seja, a de "variação, gradual ou repentina, ou combinação destas, na intensidade do som e sua graduação, do fortíssimo ao pianíssimo, na execução de um trecho musical”. Fonte: Dicionário Caldas Aulete.
} 
planície -, e por saltos intervalares de terças e quartas, considerados intervalos consoantes ${ }^{94}$ sendo consoante palavra que nos situa no campo semântico daquilo que está em conformidade ou de acordo com algo, daquilo que é harmonioso, logo, de algo simétrico, regular, uniforme.

Note-se que, no conjunto dessas cinco frases que compõem a melodia de "O mineiro e o italiano", a maior distância entre notas é um intervalo descendente de sexta. Localizado na quinta frase do grupamento, entre as notas Dó sustenido (quarto espaço do pentagrama) e Mi (primeira linha do pentagrama), esse salto intervalar mais dilatado ocorre uma única vez em toda a melodia. Para além desse seu caráter de exclusividade, faz-se necessário chamar a atenção, também, para uma questão que se relaciona ao lugar em que ele se assenta na melodia: esse salto de sexta maior realiza-se após uma fermata, elemento musical que alonga a duração da nota. Ao alongar a duração da nota que precede o salto, a fermata permite não só que o intérprete tenha tempo de parar para "pensar" na e "ouvir" a nota procedente - o que pode resultar em uma entoação mais precisa e afinada -, como conduz o ouvinte, por meio da suspensão da "nota fermatada", a não perceber o salto como tal. No limite, o espectador ouve a sequência das duas notas não como um intervalo de sexta entre duas notas mas como um intervalo entre frases. Isto o induz a ouvir o Dó sustenido como arremate de uma frase e o Mi como começo de um novo (e apartado do precedente) período melódico. Essa circunstância contribui, por um lado, para atenuar (ou mesmo anular) a dificuldade da realização do salto para o intérprete e, por outro, para mitigar (ou até suprimir) o efeito e o sentido que este produz no ouvinte. Outrossim, o fato de ser um Mi a "nota alvo" desse salto intervalar - nota que corresponde à tonalidade da canção -, também age como atenuante dos efeitos e sentidos produzidos por um salto melódico dessa monta. Destarte, a ocorrência desse intervalo de sexta maior na melodia não contribui para desestabilizar a sensação (auditiva e para além) de estarmos diante de uma melodia plana, pouco variante, tal e qual o falar caipira.

Pensando ainda no que foi acima transcrito e tendo em mente elementos que podem ser relacionados às ideias e noções ligadas ao âmbito significativo do adjetivo "igual", é possível afirmar-se que, melodicamente, as frases dois e três podem ser consideradas análogas, uma vez que ambas são formadas por quatro trechos de notas repetidas, três saltos intervalares $\left(3^{\mathrm{a}}, 4^{\mathrm{a}}, 3^{\mathrm{a}}\right.$ e $3^{\mathrm{a}}, 4^{\mathrm{a}}, 4^{\mathrm{a}}$, respectivamente) e dois trechos em que a melodia se desloca por graus conjuntos.

\footnotetext{
${ }^{94}$ Sobre este assunto ver FREITAS, 1995.
} 
Alguns dos atributos planos e das noções de igualdade (no sentido de pouca ou sutil variação) que acabaram de ser descritos, analisados e interpretados nos parágrafos anteriores podem ser facilmente observáveis, mesmo para os não iniciados em teoria, escrita e leitura musicais, por meio do próprio contorno que o desenho que as notas inscreve no papel. Vejamos novamente a melodia transcrita:
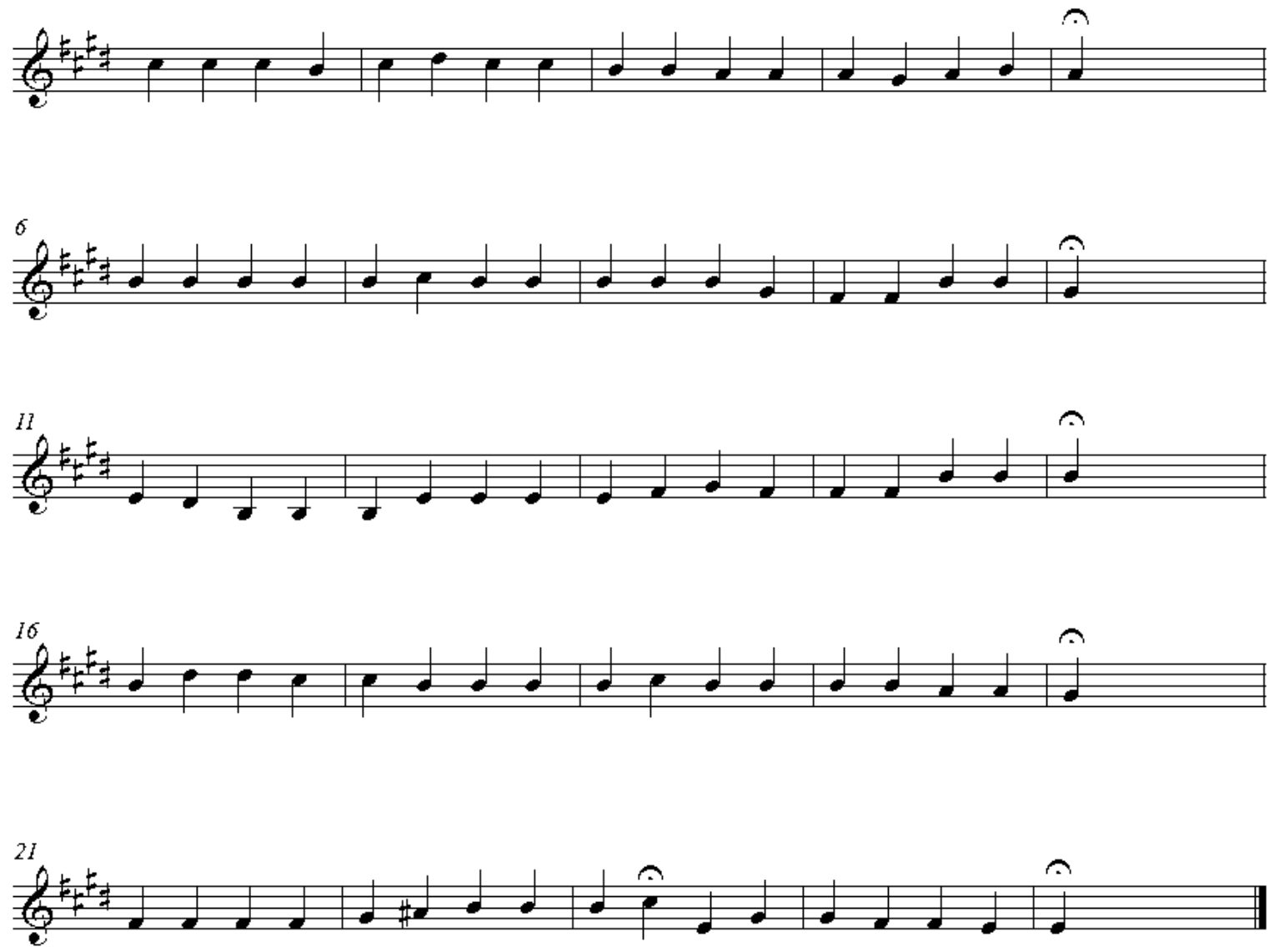

Ao observá-la, se imaginarmos estar olhando para uma fotografia onde as cabeças das notas são o traço que demarca o contorno de um relevo no horizonte, a imagem que se forma a partir deste traço imaginário de relevo está muito melhor representada por este desenho 
do que por este

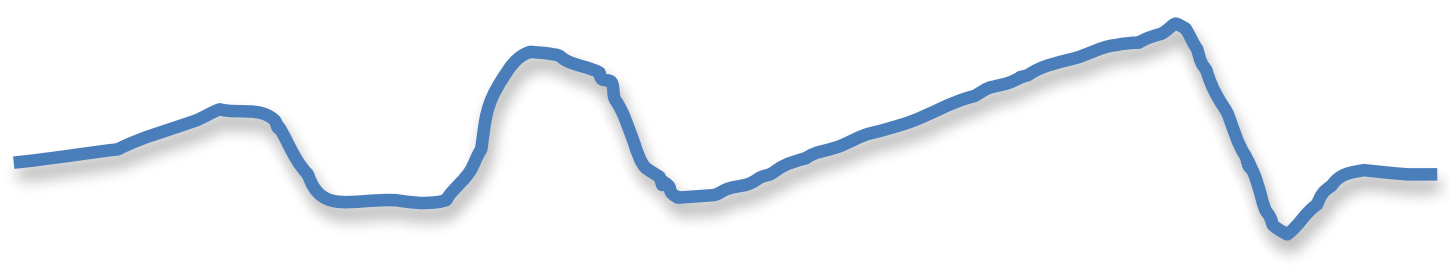

Assim, o "desenho melódico" - construído a partir de uma linha imaginária que uniria as cabeças das notas - sugere mais uma superfície plana, uma planície, do que uma acidentada.

Uma vez que, como descrito e analisado em capítulo anterior, a segunda voz cantada por Pardinho desenvolve-se em dueto de intervalos de terça (às vezes quartas) construídos a partir da melodia da primeira voz de Tião Carreiro, as mesmas relações e afirmações constantes na análise realizada a partir da transcrição da melodia da primeira voz podem ser assumidas como válidas para a segunda.

Em relação à fonética do dialeto caipira, Amadeu Amaral notou que o " $r$ inter e postvocálico (arara, carta) possui um valor peculiar: é linguo-palatal e guturalizado"; observou ainda que, em sua pronúncia, "não há quase nenhuma vibração tremulante [e que], para o ouvido, este $r$ caipira assemelha-se bastante ao $r$ inglês post-vocálico [sic]". Para o autor isso se dá "muito provavelmente" por ser este $r$ caipira "o mesmo $r$ brando dos autóctones" que, ainda de acordo com Amaral, "não possuíam o $r r$ forte ou vibrante" (AMARAL, 1920, p. 21). Exemplos disso podem ser verificados na forma como a dupla pronuncia as palavras "minêro", dormia, quero, "parenti”, "parmu”, para, "indiferenti”, "sinhor", fera, guarda, dar, porém, "vereditu”, “cunformi”, fora, coração, gorda.

Há, contudo, momentos em que esse $r$ é pronunciado "à italiana". São os casos de barra (em “vivia às 'barra' dos tribunais"), terra e derrota. Nestes casos, há vibração tremulante, a língua vindo para frente e para cima (em direção ao céu da boca) e tocando os dentes incisivos superiores. Não há, porém, o que se estranhar nestes casos!

Em primeiro lugar, porque Tião Carreiro e Pardinho tinham essa "fonética italiana" no ouvido, uma vez que ambos passaram a maior parte de suas vidas no Estado de São Paulo que 
é, como visto, aquele que recebeu o maior número de imigrantes italianos no Brasil. Em segundo, cabe notar que essa pronúncia "à italiana" ocorre quando o locutor está dando voz ao narrador da história, que, neste caso, pode ser tanto um paulista da capital ou do interior, quanto os próprios autores da moda, Teddy Vieira e Nelson Gomes. Este, nascido em Buri, passou sua vida adulta na cidade de Osasco; aquele, homem nascido e criado em Itapetininga. Ambos viveram, pois, em regiões com forte presença e influência da imigração italiana. Em terceiro, não deve causar estranheza uma vez que é notório o fato de que o Português brasileiro constituiu-se e consolidou-se como um idioma plural em sua fonética, prosódia, vocabulário, hibridismos... Negar isso é incorrer em preconceito linguístico, questão que será discutida na segunda parte deste texto.

Isso posto, acredito que esse $r$ italiano aí está, antes, por conta da habilidade artísticointerpretativa da dupla enquanto locutora da história. Tal habilidade consiste em intercalar o dialeto caipira com os diferentes modos de se falar (léxico) e pronunciar (fonética) o português do Brasil; cada um correspondendo ao personagem em questão ou ao narrador em seus respectivos momentos de fala. Em uma história que possui um narrador (que nesse caso são seus autores ou um paulista qualquer), personagens (o mineiro, o italiano, o advogado, o juiz quatrocentão) e um locutor (a dupla Tião Carreiro e Pardinho, como dito acima), é essa habilidade que dá vida e alto valor estético à narrativa e ao fonograma. O quanto essa escolha estética é consciente, premeditada e treinada (praticada como ferramenta de interpretação) talvez nunca saberemos. Mas é fato que essas mudanças e interpolações ocorrem, são perceptíveis e seguem determinado padrão no fonograma em questão.

Ainda sobre os aspectos da fonética do dialeto caipira, Amadeu Amaral escreveu que "a consonância palatal molhada lh não existe no dialeto" (AMARAL, 1920, p. 22). Na letra de "O mineiro e o italiano", isso está exemplificado na frase "[...] meus filhinhos vivem doentes", onde o substantivo filhinhos é pronunciado filinhos. O mesmo caso reaparece em "ver meus filinhos 'di a pé". Por fim, em "eu fiz conforme lhe havia dito", o lhe é pronunciado $l i$, soando a frase “conformi li havia dito". Em todos esses exemplos, o locutor está dando voz ao mineiro, ou seja, à fala do caipira. Ocorre, no entanto, que a consonância palatal molhada $l$ pode ser ouvida em "paulista da velha guarda [...]", onde ao invés de 'véia' - que, em acordo com o dialeto, seria a pronúncia esperada - a dupla canta a palavra pronunciando o "lh molhado". Observa-se aqui mais uma ocorrência interpolação apontada acima, no caso da pronúncia do $r$. A frase "paulista da velha guarda, família de quatrocentos anos" é uma fala do advogado para o mineiro, onde os intérpretes, dando voz a àquele, recorrem ao Português brasileiro em acordo com a gramática normativa da língua. Para 
reforçar essa afirmação, basta atentar-se ao fato de que além do $t h$ molhado, a dupla também faz a utilização normativa do plural em "quatrocentos anos", o que não ocorre em outros trechos da letra em que os cantores dão voz ao mineiro caipira. Isso se dá em todos os exemplos em que o plural normativo é ignorado (i.e. "o mineiro e o italiano vivia às barra dos tribunais"; "seria feio pros seus parenti"; "diga que nós 'semos' pobre"; "que meus 'filinhos' vivem doenti). A única exceção ocorre na frase "não caia nessa bestera 'sinão' nói vamu entrá pro cano"; nela, quem fala é o advogado mas, mesmo assim, a gramática normativa não é seguida. Uma possível interpretação para esse exemplo pode também ser retirada da obra de Amaral. Logo nas duas primeiras páginas da introdução de seu livro o autor escreve que o dialeto caipira "dominava em absoluto a grande maioria da população [da antiga província de São Paulo] e estendia a sua influência à própria minoria culta" e que, "ao tempo em que o célebre falar paulista reinava sem contraste sensível, o caipirismo não existia apenas na linguagem, mas em todas as manifestações da nossa vida provinciana" (AMARAL, 1920, p. 11 e 12). Em outras palavras, ainda que pertencente à classe dominante e letrada, o advogado era também caipira! Se não por completo, ao menos em suas raízes. Estes paulistas letrados e quatrocentões deixavam transparecer esse fato em costumes, gestos, algumas expressões idiomáticas e em um uso, ainda que contido e evitado, do vocabulário e do modo de falar (fonética) do caipira. Por vezes, o controle sobre a fala com visas à utilização "correta" (leiase normativa) do idioma era alcançado com o esforço da atenção e sob a memória das reprimendas de tutores recebidas em tenra idade; ou, ainda, pelo o medo de serem percebidos como iguais "aos de baixo", com o pavor do lugar que o preconceito linguístico os podia inserir. Algozes, esta classe dominante - donde saíam os poucos homens letrados daqueles tempos - jamais aceitariam possuir um lugar e um senso-comum, uma cultura, enfim, que os colocassem à mesma estatura e estrato social de suas vítimas. Daí, mesmo tratando-se da fala do advogado, ser possível observar a utilização da norma culta de forma concomitante à do dialeto caipira. Esse exemplo ilustra uma habilidade interpretativa da dupla que é ainda mais aguçada do que a suposta algumas linhas acima ou um mero acaso?

A última questão relacionanda à fonética do dialeto caipira que será abordada por este texto diz respeito às vogais. De acordo com Amaral, as vogais tônicas, "em regra, não sofrem alteração" e "o único fato importante a assinalar com relação a estas é que, quando seguidas de ciciante $(s$ ou $z$ ), no final dos vocábulos, se ditongam pela geração de um $i$ : rapaiz, mêis, péis, nóis, lúiz (AMARAL, 1920, p. 22). Na letra de "O mineiro e o italiano" isso ocorre nas frases "diga que nóis semos pobres [...]" e "não deixava os dois em paiz". Algo interessante a se notar é que essa ditongação permite que "paz", última palavra da segunda frase da primeira 
estrofe, ao ser pronunciada "paiz", passe a rimar com "tribunais", "mais" e "capitais", todas últimas palavras da primeira, terceira e quarta frases, respectivamente, dessa primeira estrofe.

Ao longo de cinco páginas Amadeu Amaral nos fornece um rol de explicações e exemplos das transformações sofridas pelas vogais (tanto tônicas quanto átonas) no dialeto caipira. Este rol está sumarizado na tabela abaixo que, além disso, traz ocorrências destas transformações observadas no fonograma de "O mineiro e o italiano":

\begin{tabular}{|c|c|c|}
\hline vogal & sonoridade no dialeto & exemplo na letra \\
\hline$e$ & $\begin{array}{l}\text { quando inicial, "aparece } \\
\text { mudada em } i \text { nasal" }\end{array}$ & $\begin{array}{l}\text { "não deixava os dois im } \\
\text { paiz"; } \\
\text { "o advogado achou } \\
\text { isquisito" }\end{array}$ \\
\hline$e$ & $\begin{array}{l}\text { quando medial "muda-se } \\
\text { frequentemente em } \\
\text { (tisôra, Tiodoro, piqueno), } \\
\text { sobretudo sehá outro ii na } \\
\text { sílaba seguinte: pirigo, } \\
\text { dilicado, minino, atrivido, } \\
\text { intiligente, pidir". }\end{array}$ & $\begin{array}{l}\text { "siria feio"; "o sinhor não } \\
\text { sabe [...]"; "Não caia nessa } \\
\text { besteira sinão [...]"; "eu } \\
\text { não acriditu"; }\end{array}$ \\
\hline$e$ & $\begin{array}{l}\text { Amaral não faz menção do } \\
e \text { quando final; em } O \\
\text { mineiro e o italino há, } \\
\text { contudo, inúmeros } \\
\text { exemplos em que o } e \text { final } \\
\text { muda-se em } i \text {. }\end{array}$ & \\
\hline$o$ & $\begin{array}{l}\text { "medial, muda-se muitas } \\
\text { vezes em } u \text { : tabuleta, } \\
\text { cuzinha, dumingo, } \\
\text { sobretudo nos infinitivos } \\
\text { dos verbos em ir, que têm } \\
\text { na sílaba imediatamente } \\
\text { anterior à tônica: ingulí(r), } \\
\text { bulí(r), tussí(r)". }\end{array}$ & \\
\hline
\end{tabular}


No que concerne aos aspectos léxicos, a letra de "O mineiro e o italiano" não contém muitos exemplos dos vocábulos que foram coletados e "dicionarizados" por Amaral. A única ocorrência verificada é a palavra angu. Esta aparece na frase “jogo meu 'deploma' fora se nesse angu não tiver mosquito". Esse substantivo tem origem africana e, sobre a existência de vocábulos africanos no dialeto caipira, Amadeu Amaral afirmou que a maior parte destes “não são aquisições próprias" sendo que, “a colaboração do negro, por mais estranho que o pareça, limitou-se à fonética; o que dêle nos resta no vocabulário rústico são termos correntes no país inteiro e até em Portugal." Uma vez mais, quando algo menos típico, peculiar ou exclusivo ao dialeto é observado na letra e em sua interpretação, isso se dá em um momento em que o locutor está dando voz não ao mineiro caipira, mas ao advogado!

Cabe aqui uma derradeira observação sobre a já citada interpolação criada pela dupla em sua interpretação. A certa altura do fonograma, Tião Carreiro e Pardinho cantam adevogado ao invés de advogado (onde o $d$ mudo tem som de $d+i$ ), invertendo assim a lógica do dialeto caipira de colocar o $i$ no lugar do $e$. A mesma inversão aparece em "jogo meu diploma fora". Sobre essa questão, recorro uma vez mais ao que atestou Amaral:

na pronúncia normal portuguesa tem-se dado, em tais casos, justamente o fenômeno contrário (dissimilação), embora nem sempre se substitua o $i$ por $e$ na escrita: menino, preguiça, vezinho, menistro. (AMARAL, 1920, p. 23)

Assim como todas as ocorrências onde advogado é pronunciado adevogado, a frase acima pertence à fala do narrador...

Por tudo que foi acima exposto, debatido e interpretado, espero ter demonstrado que o fonograma de "O mineiro e o italiano" condensa, de maneira razoavelmente ampla e interessante, os principais aspectos e características do dialeto caipira que foi inventariado por Amadeu Amaral. Para além disso, por meio da análise se pode constatar - ou ao menos especular - que a dupla Tião Carreiro e Pardinho, ao desempenhar o papel de locutor da história, demonstrou extrema habilidade artístico-interpretativa ao diferenciar a fala de cada personagem de acordo com sua classe e inserção sociais. Assim, a prosódia, a maneira de falar e pronunciar as palavras, de formar os plurais (ou de não formá-los) e as frases, o vocabulário, foram mais ou menos realizados ao modo segundo o qual cada personagem o faria, de acordo com a classe e locus social ao qual pertenceriam. A interpretação da dupla ilustra de maneira formidável aquilo que Amaral chamou a atenção, a saber, que "um dialeto bem pronunciado, [...] bastante característico[...] dominava em absoluto a grande maioria da 
população e estendia a sua influência à própria minoria culta. As mesmas pessoas educadas e bem falantes não se podiam esquivar a essa influência” (AMARAL, 1920, p. 20). 


\section{A questão da terra e do relógio}

Conforme o que se vem desenvolvendo até aqui, e de acordo com a interpretação proposta por esta dissertação, o espaço geográfico e a experiência comum da narrativa (musical e literária) de "O mineiro e o italiano" são a Paulistânia e a cultura caipira; e, seu tempo, aponta para uma cronologia que situa o caso historiado pela moda em algum lugar entre o final do século XIX e a primeira metade do XX.

Se essa interpretação for válida, em relação à questão "que horas são?” na canção composta por Teddy Vieira e Nelson Gomes, algumas perguntas que podem surgir a partir dela são: de qual ponto dessa cronologia se está falando? É possível precisá-la um pouco mais? Em outras palavras, até que ponto a narrativa da letra fornece indícios ou sugere algo para que se possa, ao menos, tornar a indicação temporal "situada em algum lugar entre o final do século XIX e a primeira metade do XX" um pouco menos abrangente?

Para este trabalho, a resposta às questões apresentadas no parágrafo anterior é: sim! Este capítulo tem por objetivo, pois, apontar, aventar e interpretar alguns ingredientes que sugerem que a demanda de terra que tirava o sono do mineiro e a paciência do italiano "ocorreu", provavelmente, no período situado um pouco antes, um pouco depois, do início da década de 1930. Para além disso, procura demonstrar porque, para o mineiro, perder a demanda e, consequentemente, sua terra, tem significados e implicações tão profundas quanto irreversíveis.

Se as razões que impeliram as incursões bandeirantes estavam ligadas à pobreza material e humana a que estavam submetidos aqueles homens ${ }^{95}$, pouco ou quase nada se alterou quando estes começaram a fixar-se um tanto mais. Os velhos paulistas engendraram uma sociedade rústica e ensimesmada que, conforme discutido nos capítulos anteriores, caracterizava-se por estar organizada a partir de "mínimos vitais marcados pela pobreza" (CANDIDO, 2017). Essa forma de organização "gerou um caráter provisório de existência e uma cultura material específica" (SETUBAL, 2005, p. 20), delineando "uma vida social marcada pelo isolamento, a independência, o alheamento às mudanças sociais" (CANDIDO, 2017, p. 56).

\footnotetext{
${ }^{95}$ RIBEIRO, 1995, p. 106 e HOLANDA, 1986, p. 26.
} 
Parte dessa existência era balizada pelo provisório pois tinha na agricultura extensiva itinerante "um recurso para estabelecer [seu] equilíbrio ecológico". É que, por meio da mobilidade, o caipira encontrava um expediente eficaz "para ajustar as necessidades de sobrevivência à falta de técnicas capazes de proporcionar rendimento maior da terra" (CANDIDO, 2017, p. 55). Na sua impermanência encontrava, da mesma forma, uma estratégia para seguir a vida quando, por algum motivo alheio à sua vontade - infertilidade causada pelo desgaste do solo, espoliação ou tentativas de subjugação, litígios e disputas via-se impedido de trabalhar a terra em que se encontrava. Quando alguma dessas situações se apresentava, o caipira migrava, procurando outro chão que lhe garantisse a subsistência. Como consequência, essa mobilidade seminômade acabava por reforçar a condição de isolamento e independência do habitante da Paulistânia, reafirmando e perpetuando sua economia como "naturalmente fechada", e agindo como "fator de preservação duma sociabilidade estável e pouco dinâmica" (CANDIDO, 2017, p. 55).

Assim sendo, no que concerne ao acesso à e aos usos da terra, as especificidades da cultura caipira historicamente se traduziram em uma realidade "em que a ocupação do solo era transitória, a propriedade não tinha registro legal, o trabalho baseava-se na unidade familiar e havia uma intensa relação com a natureza" (SETUBAL, 2005, p. 20).

Isso posto,

é preciso indicar, neste passo, que a agricultura itinerante era possibilitada não apenas pelas reservas de terra nova e fértil, imensas para uma população esparsa, como também pelo sistema de sesmarias e posses; sobretudo estas, que abriam para o caipira a possibilidade constante de renovar seu chão de plantio, sem qualquer ônus de compra ou locação. A posse, mais ou menos formal, ou a ocupação, pura e simples, vêm juntar-se aos tipos de exploração e ao equipamento cultural, a fim de configurar [a vida do caipira]. (CANDIDO, 2017, p. 56)

O excerto acima deixa evidente que o modo de vida do caipira e a obtenção de sua subsistência dependiam diretamente da disponibilidade de terras e da margem legal que o sistema de posses propiciava. Logo, enquanto houvesse "terras virgens despovoadas e desprovidas de qualquer valor" ou função mercantil de alta lucratividade a cultura caipira e a sobrevivência de seus integrantes estariam garantidas (RIBEIRO, 1995, p. 383). 
Durante os duzentos primeiros anos do povoamento da Paulistânia "a possibilidade de ocupar terras sem ônus [...] estava teoricamente aberta a todos" (FRAGOSO, 1998, p. 63-65), num cenário em que "os mais abonados [as obtinham] por concessão em enormes sesmarias e os mais pobres e imprevidentes apenas [as ocupavam] como posseiros" (RIBEIRO, 1995, p. $383)$.

Posteriormente, conforme o "avanço das condições capitalistas no campo" (SETUBAL, 2005, p. 20) era viabilizado e instituído, fazendo-se cada vez mais presente e notável, as questões relacionadas à posse, usos e propriedade da terra sofreriam significativas alterações. A partir de então, começaram a recair sobre o caipira pressões, privações, leis, instituições, cobranças que, no mais das vezes, expuseram-no a disputas e confrontos antes evitáveis, cobraram-no títulos e documentos aos quais não tinha acesso nem conhecimento, expropriaram-no a terra - impelindo-o a subjugar-se como agregado, parceiro ou empregado, no melhor cenário, e, no pior, forçando-o a desenraizamentos que geravam anomia e/ou causavam sua morte (social, cultural ou mesmo física). Esse processo histórico teve início ainda no século XVIII.

Conforme escreveu Caio Prado Jr., nos estertores do século XVIII a Paulistânia começou a "recuperar as forças exauridas em dois séculos de aventuras", inaugurando um "período de expansão e prosperidade" que se baseava na estabilidade da agricultura (PRADO Jr., 2011, p. 69). Parte significativa do capital que financiou essa expansão agrícola na região provinha do capital mercantil acumulado na "era da mineração" (FRAGOSO, 1998, p. 75) e, de acordo com Sampaio, esse círculo virtuoso "foi marcado pelo crescimento da produção açucareira" (SAMPAIO, 2014, p. 325). Isso porque, finda a abundância do ouro, em um fluxo migratório de regresso, muitos paulistânicos "retornam à sua terra e ali se instalam definitivamente" (FRANCISCO, 2004, p. 34). Parte daqueles que, como apontado no capítulo I, encontraram seu Eldorado na produção agrícola e/ou agropecuária durante o período do auge da mineração, "doravante [retornavam e transformavam] em capital o que acumularam, investindo na fabricação da cana-de-açúcar no solo fértil do interior de São Paulo" (FRANCISCO, 2004, p. 34). A partir disso,

nos vales do Tietê e do Paraíba formam-se grupos audaciosos de produtores. As melhores terras devem ficar sob sua posse, a fim de que o açúcar produzido venha a competir no mercado internacional. Reivindicam-se, então, as antigas sesmarias, inventam-se notações cartoriais, dá-se o direito de propriedade aos latifundiários, para preservar a qualidade das terras. $\mathrm{O}$ 
que outrora não tinha valor é sublimado, expropriado e utilizado. (FRANCISCO, 2004, p. 34)

Paralelamente à economia do açúcar, continuavam a dar bons frutos a "agricultura mercantil de alimentos" e o vultuoso comércio de animais que, após o declínio da mineração, encontravam novo fôlego e mercado com a transmigração da Corte portuguesa para o Rio de Janeiro. Mas, o que contribuiu para engrandecer de vez a fazenda paulistânica foi o advento da produção cafeeira, iniciada na região ainda no primeiro quartel do século XVIII e “incrivelmente aumentada nas primeiras décadas” do XIX (FRAGOSO, 1998, p. 74).

Assim, se a implantação e ampliação da lavoura canavieira abriu "uma era de desenvolvimento ao integrar a capitania ao lucrativo comércio de exportação" (MEDICCI, 2006, p. 393), o café veio para consolidá-la de vez, alterando as relações e reconfigurando fronteiras, limites e as questões relacionadas ao aceso, à posse, ocupação e propriedade da terra. Nesse processo, "com a ocupação dos latifúndios para a economia agroexportadora, as famílias mais pobres vão procurar alhures um espaço em que possam sobreviver" (FRANCISCO, 2004, p. 34), pois a mão-de-obra excedente e ociosa que representavam não foi aproveitada pelos latifundiários. Estes, por diferentes razões, buscaram no escravo, e depois no imigrante, os braços que precisavam para implantar seu projeto ${ }^{96}$. Estigmatizados enquanto força laboral, considerados vagabundos, incompetentes e inaptos ao trabalho, disciplina e regularidade que o latifúndio exigia (KOWARICK, 2019), aqueles homens livres e pobres, "que viviam em comunidades, sob economia de subsistência", enredariam um processo sucessivo e prolongado de renovação de sua transitoriedade, buscando sempre novas e distantes terras, "firmando-se em locais distintos do latifúndio" (FRANCISCO, 2004, p. 34). Nos bairros rurais, nas bordas das grandes fazendas, na ampliação das fronteiras, no limite da marginalização, iam confirmando sua condição de isolamento, independência, rusticidade, pobreza. Vivendo e renovando suas posses perpetuavam "a provisoriedade dos primeiros tempos, sem garantias" (FRANCISCO, 2004, p. 34).

Enquanto foi possível, essa estratégia se traduziu em uma forma eficaz de manutenção de seu modo de viver e cultura. Com o café, porém, a ocupação lucrativa do solo atingirá seu auge e sua exploração inviabilizará essa dinâmica de renovação e sobrevivência que o caipira experienciou. À época do café, a disponibilidade de terras deixou de existir, "um palmo de terra a mais" deixou de ser indiferente e o caipira viu-se privado de sua estratégia mais antiga

\footnotetext{
${ }^{96}$ Sobre as questões e razões que condicionaram este processo ver KOWARICK, 2019.
} 
de subsistir, constituindo-se, as fazendas de café, como "o primeiro grande abalo à cultura caipira, seguidas pelo processo de industrialização” (SETUBAL, 2004, p. 22-23).

O processo histórico suscitado pelo café condicionou a economia, a política, as relações sociais, da Paulistânia e do Brasil, por mais de cem anos. Sua evolução histórica deu novo perfil à região e mudaria para sempre os destinos de sua vida material e da de seu povo.

Desde fins do século XVIII e conforme avançava o XIX, o consumo mundial de café aumentava e o cultivo da planta configurava-se como interessante mercado (FURTADO, 2000, p. 114). Reunindo condições ideais de clima, terras disponíveis, mão de obra e capitais subutilizados ou ociosos, o Brasil não tardou a inserir-se de forma vigorosa nesse mercado. Já no início da década de 1830 "o café passou a se destacar na pauta de exportação" do recém estabelecido Império e, seu cultivo, a expandir-se em direção ao Oeste paulista; não levaria muito tempo para que se alastrasse e cobrisse vasta área da Paulistânia (FURTADO, 2000, p. 94-95; FURTADO, 2007, p. 147, 169, 170 e 252). Na segunda metade do Oitocentos "o café tornou-se, então, o elemento dinâmico da economia brasileira” (FURTADO, 2000, p. 115; RIBEIRO, 2006, p. 357) e, nos anos finais do Império, o Brasil era responsável pela produção de "mais de $80 \%$ do café exportável em todo o mundo" (FURTADO, 2000, p. 115). Na virada para o século XX, o "ouro verde" era, de longe, o produto mais representativo da pauta exportadora do país.

Nem mesmo o processo de abolição da escravidão abalou

o pólo de maior crescimento econômico, que era a Província de São Paulo, porque, desde a suspensão do tráfico de escravos, o planalto paulista recebeu numerosos contingentes de imigrantes que satisfizeram, em grande parte, as necessidades das regiões cafeeiras em plena expansão. (FURTADO, 2000, p. 109)

Sobre isso Darcy Ribeiro escreve que

as classes dominantes reestruturaram eficazmente seu sistema de recrutamento da força de trabalho, substituindo a mão de obra escrava por imigrantes importados da Europa, cuja população se tornara excedente e exportável a baixo preço. (RIBEIRO, 1995, p. 221) 
Contemporânea ao fim do regime monárquico brasileiro, como parte e consequência "do movimento da abolição da escravidão", a grande imigração ocorre, principalmente, a partir do "segundo lustro da década de 1880", "a fim de suprir as fazendas de café com mãode-obra" (PETRONE, 1978, p. 103). Segundo Maria Tereza Schorer Petrone, "a produção de café, depois da introdução em massa de imigrantes, aumentou tremendamente [...]", sendo a imigração uma das principais responsáveis "pela extraordinária expansão dos cafezais que perdurou praticamente até a crise de 1929” (PETRONE, 1978, p. 115). Nesse transcurso, “a lavoura cafeeira foi responsável direta ou indiretamente pela vinda de 2,5 milhões de estrangeiros, na grande maioria italianos" (SETUBAL, 2004, p. 25). Para Celso Furtado, foi essa a grande "corrente imigratória que tornaria possível a expansão da produção cafeeira no estado de São Paulo" (FURTADO, 2007, p.121).

Ademais, esses imigrantes italianos, "já [adaptados] ao regime salarial”, aqui chegaram predispostos "a [esforçarem-se] ao máximo para conquistar [...] um palmo de terra em que [pudessem] prosperar, [livres] da exploração dos fazendeiros” (RIBEIRO, 1995, p. 221).

A possibilidade de um dia se tornar proprietário de terra foi uma das molas propulsoras do processo imigratório para o Brasil. [...] O imigrante que vinha para São Paulo acreditava que depois de alguns anos de trabalho na fazenda de café pudesse comprar seu pedaço de terra. [...] A pequena propriedade surgiu devida à pressão do imigrante e apesar da vontade do fazendeiro de café. (PETRONI, 1978, p. 117-118)

Foi assim que, decorrido algum tempo, "a maioria das pequenas propriedades estava nas mãos de estrangeiros", predominantemente nas de italianos, que eram donos de " $66,4 \%$ [do total] das propriedades de estrangeiros" (PETRONE, 1978, p. 120).

Mais uma geração e "os italianos aparecem em quase todas as áreas onde se formam pequenas propriedades, sendo digno de nota que já no início do século $[\mathrm{XX}]$ havia extensas áreas onde os italianos se concentravam" (PETRONE, 1978, p. 117). Alguns deles fariam fortuna e tornar-se-iam poderosos e influentes, passando de "colonos a fazendeiros" em menos de cinquenta anos (SCATIMBURGO, 2006, p. 252; RIBEIRO, 2006, p. 362; SANT'ANNA, 2009, p. 328-329). A partir de então, este italiano-caipira, transfigurado ele, 
também como "novo rico" 97 e proprietário de terras, vai agir em acordo com os interesses da classe à qual acabara de se integrar como membro, pois, no que concerne ao social, pode-se afirmar seguramente que "o café suscitou uma classe" (SCATIMBURGO, 2006, p. 238).

Caio Prado Jr. afirmou que o café deu origem "à última das três grandes aristocracias do país, depois dos senhores de engenho e de mineradores" (PRADO Jr., apud CAMARGO, 2004, p. 129). Sobre o mesmo assunto, em seu livro Síntese da Economia Brasileira, Milton Braga Furtado escreveu que "a expansão da cultura cafeeira gerou uma nova aristocracia rural - a do barão do café, que se constituiu em uma classe econômica poderosa, com objetivos essencialmente capitalistas, como a propriedade, o lucro e a acumulação de capital" (FURTADO, 2000, p. 117).

Essa nova aristocracia econômica logo se confirmaria como elite política e administrativa, ocupando todas as esferas do poder e caracterizando-se por defender seus interesses - fossem eles de qualquer ordem - de maneira ferrenha, interessada e desproporcional, desafiando poderosos, remediados e despossuídos de igual modo. Tal práxis se realizaria de forma idêntica na esfera da Justiça (RIBEIRO, 2006, p. 364) e atingiu seu auge com "a conquista da autonomia estadual, ao proclamar-se a República" (FURTADO, 2007, p. 172). Assim, não era rara a situação em que fazendeiros de café, juízes, bacharéis, quatrocentões ou "novos ricos", partilhavam os mesmos interesses e objetivos, orbitam as mesmas instituições, ocupavam ou decidiam quem ocuparia cargos importantes, manipulavam a economia, aparelhavam o Estado...

Resultado de sua expansão e efeito de sua importância: o café, para além de

\footnotetext{
${ }^{97}$ O termo "quatrocentão" designa as antigas famílias de São Paulo, descendentes dos primeiros colonizadores e chefes das bandeiras, distinguindo-as dos chamados "novos-ricos", descendentes de imigrantes de diversas nacionalidades, relativamente recém-chegados (pois chegaram em fins do Império do Brasil (1822-1889), que ensaiavam formar uma nova categoria social. A condição de "quatrocentão" se opõe à dos "novos ricos", burgueses descendentes de imigrantes inicialmente muito pobres, alguns dos quais também bem sucedidos nos negócios a partir dos anos 1880 mais ou menos, como o terceiro "rei do café", o prussiano Francisco Schmidt (1850-1924), e o quarto "rei do café", o italiano Geremia Lunardelli (1885-1962).
} 
consolidar o deslocamento do eixo dinâmico da economia do país para o Sudeste, repercutiu, para o bem ou para o mal, "em todos os setores da vida nacional" (FURTADO, 2000, p. 94; RIBEIRO, 2006, p. 350).

No que tange a propriedade da terra, por exemplo,

estudos têm demonstrado que a expansão das fronteiras geográficas e políticas, de modo a ampliar as terras pertencentes aos membros de uma mesma família e, simultaneamente, estender seu poderio político e social a essas novas localidades, constituiu um fenômeno comum no desbravamento do território paulista. Isso ocorreu especialmente no oeste, a partir do século XIX, com a lavoura do café. (SETUBAL, 2004, p. 55)

Sobre esse processo, Darcy Ribeiro observa que "todo um aparato jurídico citadino se [colocou] a serviço" da concentração de terras nas mãos de poucos (RIBEIRO, 2006, p. 350). Somado a isso, agiram como catalisadores desse mecanismo: a Lei de Terras de 1850, a abolição da escravidão em 1888, a Proclamação da República em 1889 e as correntes imigratórias do final do século XIX e início do XX.

Assim, a partir do surgimento e da viabilização do café enquanto economia de exportação baseada na grande lavoura, e como produto das medidas e processos históricos acima citados, toda uma reordenação social, institucional e fundiária se opera no país, tendo a Paulistânia em seu centro.

No âmbito dessa reorganização, a mentalidade capitalista da nova aristocracia rural simbolizada pelo "barão do café" e a forma como a produção e a economia cafeeira foram organizadas e desenvolveram-se, associadas, modificaram as condições históricas de acesso à terra $^{98} \mathrm{e}$, por conseguinte, as relações entre posseiros, pequenos proprietários e grandes fazendeiros (RIBEIRO, 2006, p. 348-349). Nesse novo quadro de relações que se formava, enquanto houvesse terras desocupadas abundantes, os litígios entre latifundiários, pequenos proprietários e posseiros seriam diminutos e/ou de desburocratizada resolução (por meio, por exemplo, da mobilidade-migração tão real como presente no modo de vida do caipira pobre e posseiro). Contudo, como descreveu Celso Furtado (FURTADO, 2007, p. 233-234), a expansão da produção cafeeira (assim como dos lucros obtidos com ela) no Brasil, não se

\footnotetext{
98 “É enganoso supor que a ocupação territorial, na colônia, tenha-se dado somente através da sesmaria. A posse, pura e simples, constitui-se, na realidade, na forma mais comum de acesso à terra, em particular nos lugares onde pessoas com grandes capitais não se impuseram de maneira dominante. Durante toda sua história, o Brasil registrou um alto grau de movimentação de seus habitantes" (FRAGOSO, 1998, p. 63).
} 
realizou pelo aumento de produtividade, mas, sim, pela ampliação da área cultivada, num processo que se baseou "amplamente na utilização do fator terra" (FURTADO, 2007, p.169170; RIBEIRO, 2006, p. 366).

Somado a isso, é preciso lembrar que a época do café coincide com o período "em que se recorrem às últimas obras acessíveis e aproveitáveis de terras virgens" (PRADO Jr., 2011, p. 147). Nessa marcha, já no início do século XX a disponibilidade de terras desocupadas e a descobrir - que outrora propiciavam acesso à posse por meio da mobilidade e expansão constantes, evitando ou mitigando dissabores e disputas -, era mínima ou mesmo não existia. Em conjunto, esses fatores histórico-estruturais fizeram com que a pressão econômica sobre a terra (e por extensão sobre o caipira posseiro) aumentassem proporcionalmente ao aditamento da lucratividade e expansão da produção cafeeira.

Ora, em seu caminho, o avanço da expansão (geográfica e econômica) cafeeira não encontrou óbices significativos pois, além de contar com o aparato jurídico e político à seu dispor, estava estruturado a partir de uma situação em que "somente uma forte alta nos preços da mão de obra poderia interromper" o crescimento dos cafezais (FURTADO, 2007, p.170). Por uma somatória de fatores ${ }^{99}$, dentre eles a reserva de mão de obra que a população caipira pobre configurava e a oferta gerada pela imigração em massa (KOWARICK, 2019), “o setor cafeeiro pôde [...] manter seu salário real praticamente estável durante a longa etapa de sua expansão" (FURTADO, 2007, p. 220). Com isso, seu avanço (e o apetite por cada palmo de terra gerado em decorrência dele) acabaria por suscitar conflitos que até então não eram recorrentes. Num andamento em que, de forma progressiva, crescente e constante, pedaços de chão foram sendo reivindicados e documentados como propriedade de alguém (de acordo com o processo, estrutura e objetivos de expansão-concentração-apoderamento acima citados), as terras devolutas ou desocupadas tornavam-se cada vez mais escassas. Isso tudo desembocaria em uma situação em que a possibilidade de acesso à terra, sem ônus, deixava de ser uma possibilidade aberta a todos (FRAGOSO, 1998, p. 60), dando vez a uma realidade em que os conflitos entre classes concentrar-se-iam nas questões ligadas ao acesso, posse e propriedade da terra. Desse modo, se ao longo do século XIX "quase não há referências a conflitos" entre grandes e pequenos (FRANCO, 1997, p. 95), conforme a terra se tornou "objeto de interesse dos mais enriquecidos" - como mercadoria e fator essencial para a expansão da produção e lucros cafeeiros -, as tensões e disputas entre grandes e pequenos se avolumaram, chegando, por vezes, aos tribunais (FRANCO, 1997).

\footnotetext{
${ }^{99}$ Ver FURTADO, 2007, p. 218-222 e 232.
} 
Em virtude dos processos de acesso à terra herdados dos tempos coloniais, na Paulistânia "a maior parte das propriedades rurais era resultante da posse com limites vagos, definidos por acidentes geográficos" (CAMARGO, 2004, p. 129).

Com a expansão canavieira e cafeeira, a situação dessas glebas de estatuto jurídico duvidoso preocupava os seus proprietários. Suas pressões contribuíram para a aprovação da [Lei de Terras], regularizando assim a situação obscura quanto à posse de terras gerada desde a supressão da concessão de sesmarias em 1822. A partir da regulamentação de 1850 , as terras no Brasil pertenciam ao Estado e só podiam ser obtidas mediante compra. O negócio costumava ser vantajoso quando se compravam grandes extensões para o desenvolvimento da lavoura de exportação. Mas, para lotes pequenos e médios, os preços eram elevados, de modo que os trabalhadores livres não podiam adquiri-los. (CAMARGO, 2004, p. 129)

Conforme se pode inferir a partir da leitura do trecho acima, em teoria a Lei de Terras, "que passou a vigorar em 1850, [visava] regularizar a situação fundiária em todo o território [brasileiro]" (CAMARGO, 2004, p. 129). Na prática, ela foi pensada e implantada para evitar que o imigrante recém-chegado fosse, de imediato, capaz de comprar uma porção de terra e tornar-se pequeno proprietário, pois isso frustraria o ímpeto do fazendeiro que o "importava" como mão-de-obra substituta ao escravo; jamais para tornar-se proprietário de terra.

Conforme discutido há pouco, uma parcela desses imigrantes conseguiu contornar essa situação, boa parte tornando-se sitiante e, uma minoria, fazendeiro. Assim, se já nos dez primeiros anos do século XX “aparecem pequenas propriedades onde se produziu café, como é o caso dos italianos no bairro do Morro do Cipó, próximo a Ribeirão Preto" (PETRONE, 1978, p. 120), houve casos de italianos que chegaram a ser grandes latifundiários, como o imigrante Geremia Lunardelli (1885-1962), considerado “o quarto rei do café”.

Acontece, porém, que a lei de 1850 atingiu igualmente o homem pobre livre caipira. Ao contrário do imigrante italiano, entretanto, o posseiro caipira raramente conseguiu reverter a situação que a ele se impunha. Obrigado ou a comprar terras às quais os preços orbitavam muito além de seu poder aquisitivo ou compelido a "formas de legitimação cartorial da posse" às quais eram a ele inacessíveis (RIBEIRO, 1995, p. 386), via de regra era "expulso da sua posse, nunca legalizada" e, uma vez "despojado da sua propriedade, cujos 
títulos não existiam [...], persistia como agregado, ou buscava no sertão novo, onde tudo recomeçaria" (CANDIDO, 2017, p. 97). Nesse sentido é que

a Lei de Terras $[\ldots]$ vem dar o golpe definitivo nos posseiros, naqueles que se instalaram no pouso transitório de outrora. Sem documento que lhes garanta a propriedade, vão viver em terra sem qualidade, infértil. (FRANCISCO, 2004, p. 34)

Isso enquanto lhes foi possível pois, quando o avanço das pressões fundiárias causadas pela expansão do café atingiu seu ápice, a indisponibilidade de terras tornava-se a regra, quase não havendo "sertão novo" por onde se recomeçar. A mobilidade, agora "limitada pelo sistema de propriedade [...] e pela densidade demográfica" (CANDIDO, 2017, p. 203), deixava de ser a solução para o caipira restabelecer e a reafirmar sua independência, modo de vida e subsistência. A partir de então, quando "um determinado meio se exauria", ou o posseiro era expulso de sua terra "por grileiros e capangas" (CANDIDO, 2017, p. 97 e 203), o caipira pobre não encontrava mais condições de corrigir essa situação pela mobilidade. Sem possibilidade de alhures recriar seu meio, o que o permitiria alcançar seu equilíbrio e garantir sua sobrevivência, o recém expropriado via-se diante de uma condição de "desequilíbrio e crise" (CANDIDO, 2017, p. 203).

Assim sendo, de sua parte, com a Lei de Terras de 1850 e "o crescimento prodigiosamente rápido das culturas de café" (RIBEIRO, 1995, p. 388), o caipira posseiro viu-se destituído não só do acesso à terra como também de sua posse. Em última instância, viu-se privado de seu modo de ser e existir.

Conforme enunciado há pouco, o período do café é coetâneo àquele em que, em uma significativa parte da antiga Paulistânia, as últimas porções de terras virgens e/ou desocupadas estavam disponíveis. O avanço dos cafezais contribuía para piorar essa situação pois, como visto, a empresa cafeeira, quanto à sua organização material, caracterizou-se, além dos baixos custos monetários, pelo crescimento por extensão (FURTADO, 2007, p.170 e 177). Nesse cenário, à medida em que a economia do café crescia, a apreciação do valor monetário da terra e a cobiça dos grandes proprietários cresciam de forma diretamente proporcional. 
$\mathrm{Na}$ contra-mão desse processo, a quantidade de terra disponível ou desocupada se tornava cada vez menor, e, por corolário, a situação do caipira pobre só piorava. Isso porque, cada vez mais sem terras às quais recorrer, esse caipira via-se privado da "mobilidade" que restaurava seu "equilíbrio" de subsistência, da mobilidade que lhe garantia os mínimos vitais, da mobilidade, enfim, que o tornava menos sensível aos desmandos e à ganância de latifundiários sempre ávidos por "um palmo de terra a mais".

Assim, à época em que a economia cafeeira atingia seu auge, sem ter, literalmente, para onde correr - e, no mais das vezes nem a quem recorrer -, o caipira pobre, quando espoliado de sua antiga posse, perdia de uma só vez não só um de seus bens mais preciosos e definidores como também um dos meios mais antigos e estruturantes de garantir sua subsistência $^{100}$.

É nesse sentido que se deve apreender que "a influência da produção cafeeira afetou a vida dessas populações que dependiam do solo e da lavoura (MANOEL, 2016, p. 86)". É nesse sentido, portanto, que a demanda de terra dramatizada pela letra de "O mineiro e o italiano" ganha ares de "questão de vida ou morte", a ponto do mineiro perder o sono, pedir favores e se esforçar para criar laços cordiais, cogitar (talvez) corromper o juiz.

Dada a gravidade da situação que se imporia ao mineiro caso este perdesse a demanda, com as implicações e privações que viriam a reboque, o personagem não vê outra alternativa a não ser ganhar o processo a qualquer custo, mesmo que para isso tenha que mentir, trapacear, perjurar. Daí recorrer à astúcia para enganar o juiz e conquistar um veredicto favorável. Donde, a ação que dela resulta, imputável como crime de falso juramento perante o Tribunal, ser justificável. E, no limite, aceitável e perdoável, dado que "foi Deus no céu [que] deu esse plano". Mais do que ganhar a demanda, o que estava em jogo era salvar a vida de sua família, garantir seu único meio de subsistência e preservar o bem ao mesmo tempo incomensurável e inefável, que lhe dá razão e condição de viver e sentido à vida.

Para além da "questão da terra", a situação envolvendo o mineiro, com seus ingredientes e pela maneira como ela é apresentada pela canção, conota também questões

\footnotetext{
${ }^{100}$ A cultura caipira "tem sua origem e sua história fundadas na relação com a terra. (SETUBAL, 2005, p. 96)". Assim sendo, o caipira típico encontra "na terra, no contato com a natureza, a constituição de seu modo de ser e existir, estabelecendo um sistema de troca e interação de relação permanente" (SETUBAL, 2005, p. 95).
} 
relacionadas ao tempo da narrativa.

Mesmo que, historicamente, "a autoridade pública [esteve] sempre [referida] a instituições alheias ao mundo caipira" (FRANCO, 1997, p. 34), com o avançar da modernização burocrático-jurídico-admnistrativa vivida por São Paulo, a partir principalmente da Proclamação da República, essa situação começa a ser alterada. Ainda que essa modernização, bem como o alheamento e o isolamento que por tanto tempo caracterizam e condicionaram a vida do caipira, principalmente o caipira pobre, jamais tenham sido revertidos ou finalizados por completo, o avanço da capilaridade dos órgãos públicos e do acesso a essas instituições por parte de uma população excluída ou marginalizada foi, paulatinamente, se tornando tanto possível quanto real.

Se esse avanço pode ser sentido com o transcorrer do século XX, os fatos de um caipira pobre ter conhecimento da existência de uma burocracia estatal e de um sistema jurídico, demonstrar noção de seus direitos, contratar um advogado, e conseguir fazer com que seu problema chegue a um Tribunal de Justiça, sinalizam uma etapa já adiantada desse processo.

É neste sentido que se deve apreender que, para além de afetar negativamente a vida daquelas populações que dependiam do solo e da lavoura para sobreviver, ao transformar e modernizar os "centros urbanos em formação e expansão pelo interior do estado (MANOEL, 2016, p. 86)" a produção cafeeira também os impactou, ainda que em menor grau, de forma positiva.

Ainda que, como dito, a reversão de um isolamento que alheava esse caipira não só das mudanças sociais, como de suas causas e daquilo que ele poderia fazer para evitá-las, delas se defender ou a elas se opor, nunca tenha se realizado por completo, uma progressão dessa monta, tanto no que concerne ao aumento da capilaridade das e do acesso às instituições, quanto à uma tomada de consciência por parte da sociedade, leva, quando de modo célere, pelo menos duas gerações para ser observável e/ou sentida em seus efeitos concretos. Logo, partindo do período em que a modernização em questão passa de fato a ser empreendida a década de 1930, chega-se, fazendo-se as contas, à soma de tempo correspondente a mais ou menos duas gerações.

Em suporte à esse argumento, acorre o italiano. Posto que café e imigrante são “termos intrinsecamente ligados à literal 'tomada' de todo o interior de São Paulo pela lavoura cafeeira entre o final do século XIX e o início do século XX” (CAMARGO, 2004, p. 140), na história da canção, conforme dito anteriormente, a presença do imigrante italiano acaba por se configurar como um interessante marcador temporal. $\mathrm{O}$ fato do italiano ser, 
supostamente, um imigrante já enriquecido, proprietário de terra, contribui para tornar esse marcador um pouco mais preciso, colocando mais uma vez o entorno da década de 1930 como possibilidade plausível.

Conforme apontado no Capítulo II, "no Brasil, uma grande parte dos imigrantes dirigiu-se para a grande fazenda de café" (PETRONE, 1978, p. 96). Esses "grandes agrupamentos de imigrantes, sobretudo italianos, que desembarcam nos primeiros anos da República, [aumentaram] a produção cafeeira e [expandiram] as fronteiras: das fazendas, dos núcleos urbanos para lugares despovoados" (CAMARGO, 2004, p. 140). Ora, foi observado que um número significativo daqueles italianos tornou-se proprietário de terras, alguns chegando a se afirmar como latifundiários. Mas, não se deve esquecer que a esmagadora maioria daquela gente chegou pobre ao Brasil, precisando do tempo de algumas gerações para concretizar a ascensão vertical discutida no capítulo anterior. Fazendo-se outra vez as contas, novamente os anos que circundam a década de trinta do século XX apresentam-se como cronologia razoável. Assim, se a Proclamação da República confirma a chegada da elite cafeeira ao poder econômico e político no país, ao mesmo tempo em que incrementa "a grande imigração", a Crise de 1929 se apresenta como um bom marco da ascensão de muitos daqueles imigrantes. Outrora colonos, ao tempo em que uma parcela de velhos quatrocentões sentia os efeitos da quebra da bolsa de Nova Iorque, alguns daqueles imigrantes (ou seus filhos) aproveitavam os espólios para se tornar proprietários de terra. Ou para completarem, de palmo em palmo de terra, o caminho de ascensão rumo à constituição de seu latifúndio.

Por fim, no intuito de fornecer mais um indício que colabore para se inferir o tempo em que se passa o caso da demanda de terra, intima-se o personagem do magistrado.

O juiz de "O mineiro e o italiano" é "descendente de família tradicional paulistana" e, na narrativa, é caracterizado como quatrocentão. Como visto anteriormente, o adjetivo “quatrocentão" ganhou a acepção corrente por volta da década de 1930, principalmente a partir da Revolução Constitucionalista de 1932. Assim, antes desse período e fora do contexto histórico que o deu razão de se configurar como tal, imaginar alguém ter a alcunha de, ser descrito e reconhecido por quatrocentão, tendo no adjetivo uma forma de distinção e um aumentativo de suas qualidades positivas, parece configurar um anacronismo às avessas, criando um avant la lettre inconcebível para o enredo que a letra cria e para a experiência histórica que retrata. 
† Coda

Nesta dissertação a música caipira, a partir do fonograma da moda de viola "O mineiro e o italiano", composição de Teddy Vieira e Nelson Gomes gravada em 1964 pela dupla de música caipira Tião Carreiro e Pardinho, foi considerada enquanto um registro dos modos de ser, ver e existir do caipira e de sua cultura.

Como se procurou perceber, apontar, analisar e interpretar, sua síntese e sentidos evocam e/ou sugerem aspectos constituintes e singularizantes do modo de vida e da cultura caipira, bem como do processo histórico da Paulistânia.

Por meio de seus personagens, de seu enredo, e das relações nela sintetizadas, conforme visto, esta moda de viola trata ou sugere temas, processos e experiências tais como as relações com a terra e sua posse e/ou propriedade, a natureza e a vida na roça; a simplicidade no modo de ser e nos costumes; o linguajar e a religiosidade caipiras; o destino; as diferentes dimensões do tempo, as tradições e a modernidade, as festas e o lazer; noções de justiça e astúcia, o humor.

Conforme demonstrado, tal e qual sua letra, a narrativa musical de "O mineiro e o italiano" encerra um interessante e igualmente potente poder de síntese e evocação.

Assim, em conclusão, afirma-se que: quando considerado em sua totalidade, este registro fonográfico demonstra força evocativa e potencial sugestivo capazes de produzir uma interessante síntese. Ao mobilizar todo um conjunto de personagens, signos, símbolos, relações, lugares-comuns, os elementos constitutivos e formais do fonograma apontam e/ou presumem elementos característicos e aspectos importantes da história e experiência do caipira e de sua cultura. Por meio da descrição, comentário, análise e interpretação do conteúdo que dá sentido e coesão à narrativa (literária e musical), esta dissertação intentou investigar em que medida essa canção popular pode ser compreendida enquanto síntese do processo histórico e da experiência histórica e cultural da Paulistânia. 
Anexos

a) Anacruse do recortado de viola

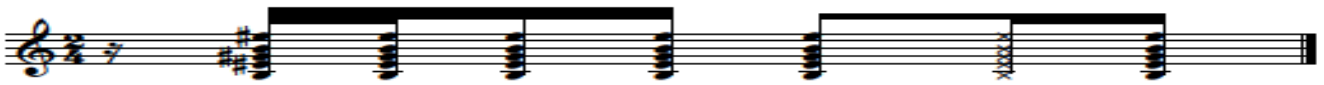

b)

O mineiro e o italiano

Introdução de viola caipira de Tião Carreiro

Parte I
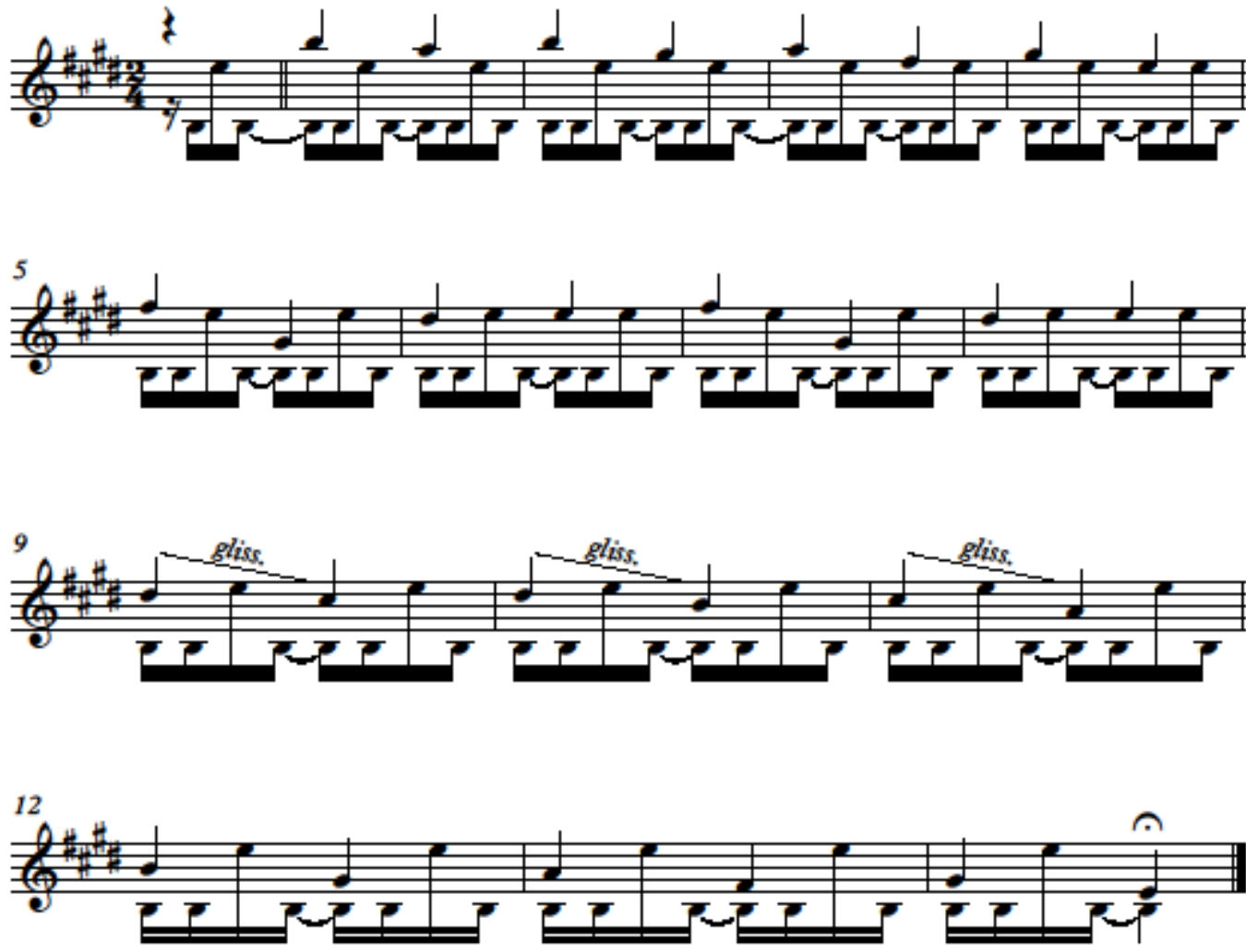
c)
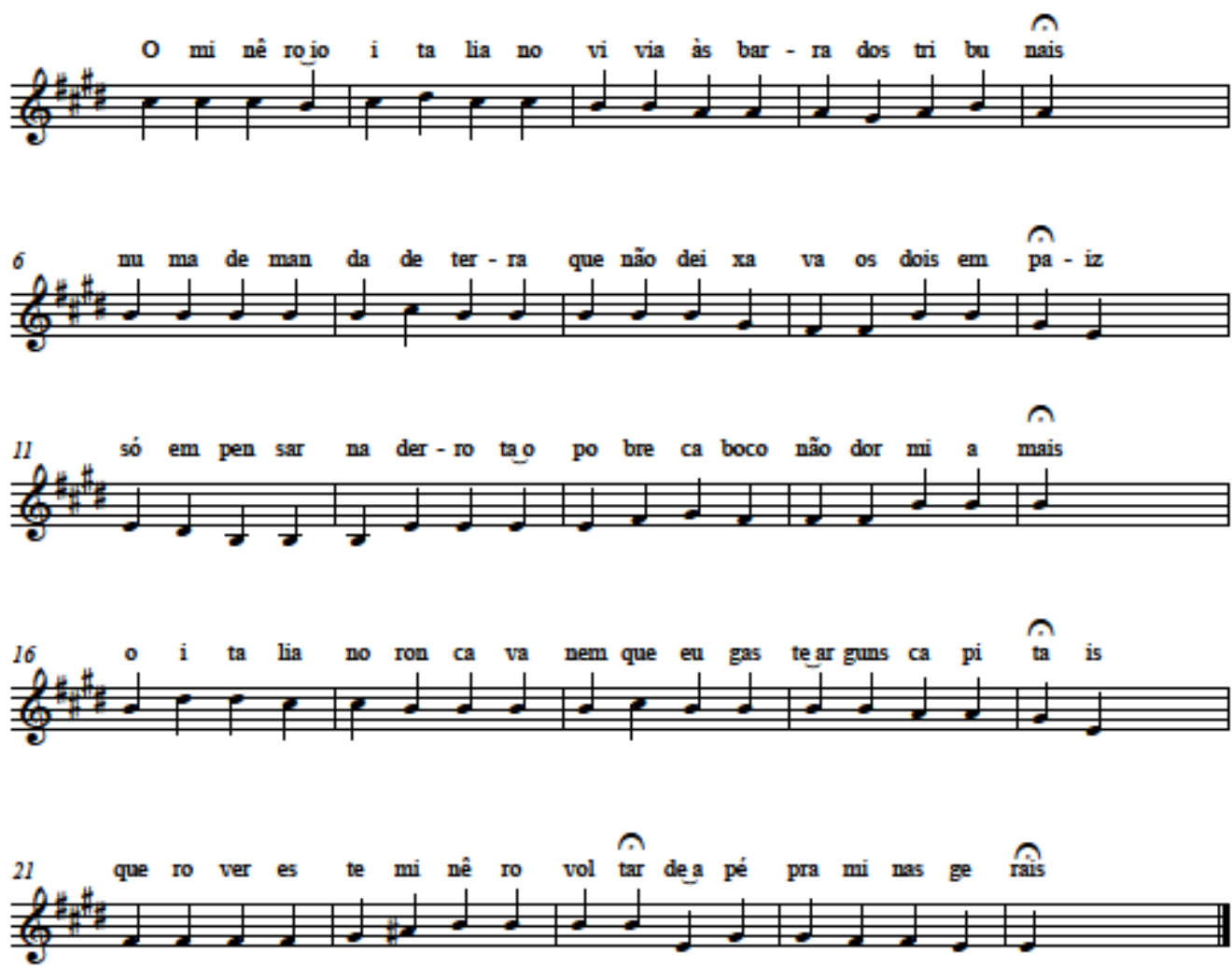

d)

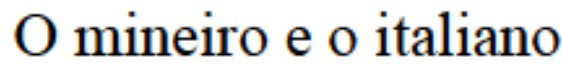

versão Conversa Ribeira
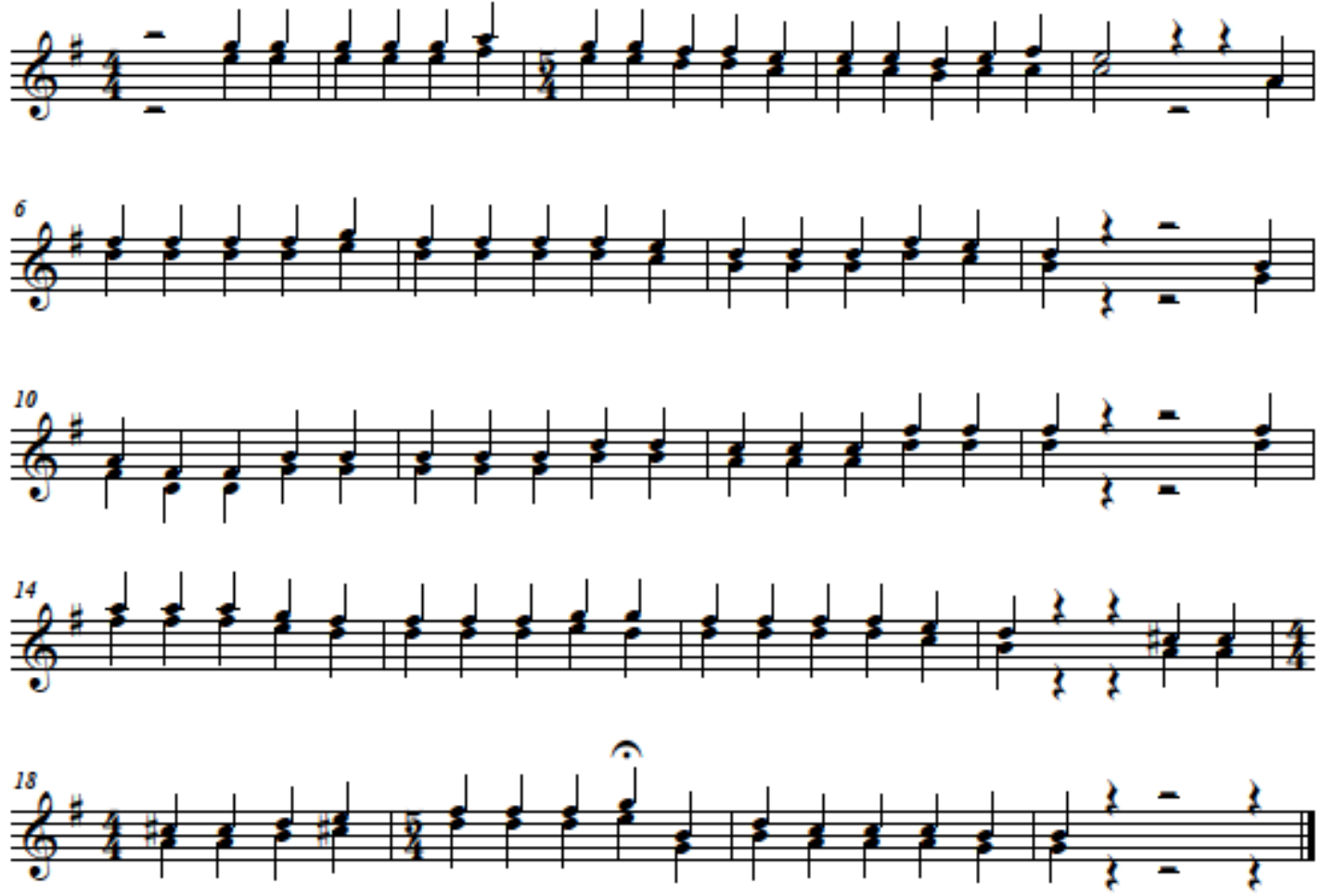
e)

O mineiro e o italiano

versão Tião Carreiro
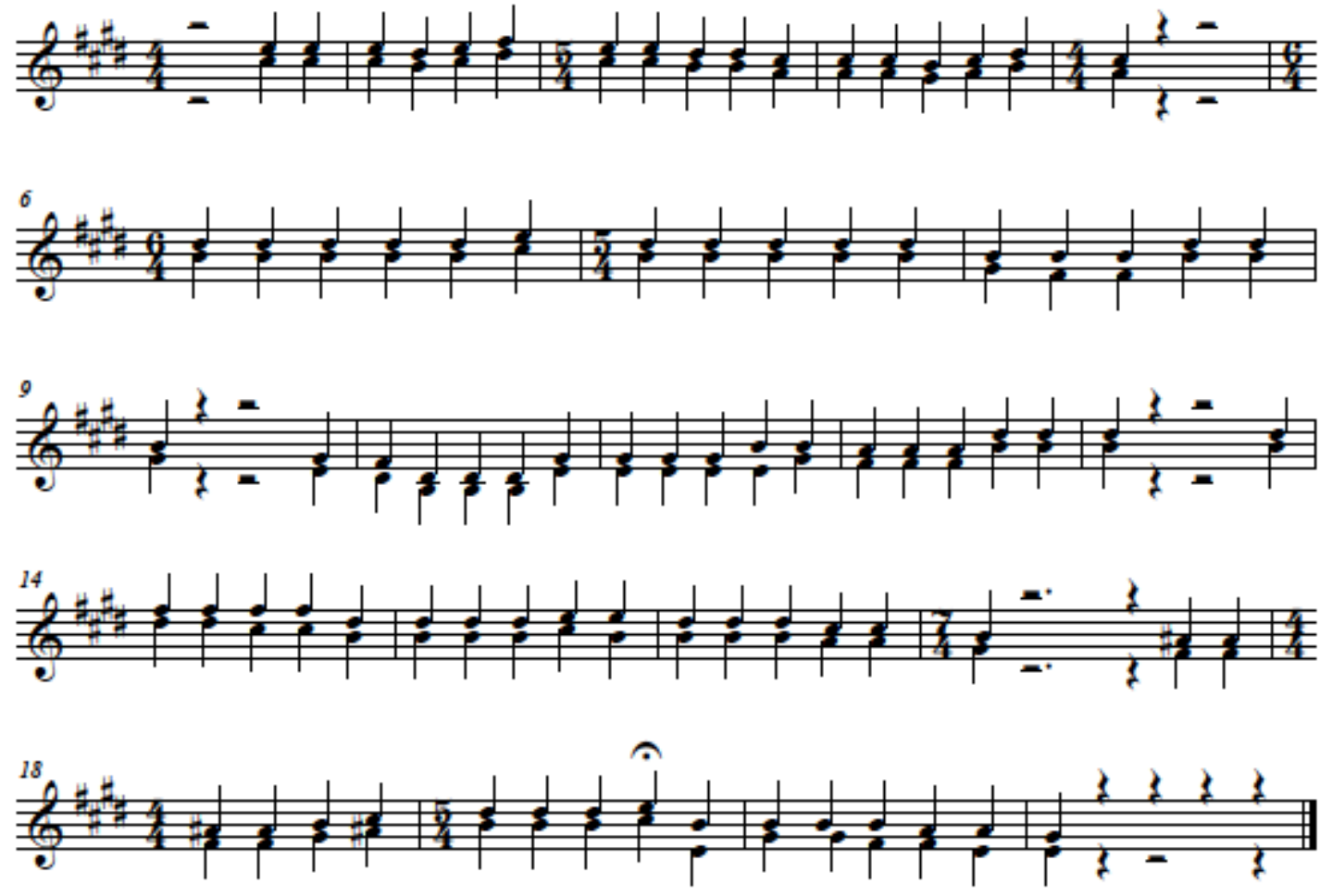
135

f) Transcrição da rítmica da melodia - sugestão do baterista Rodrigo Digão Braz.

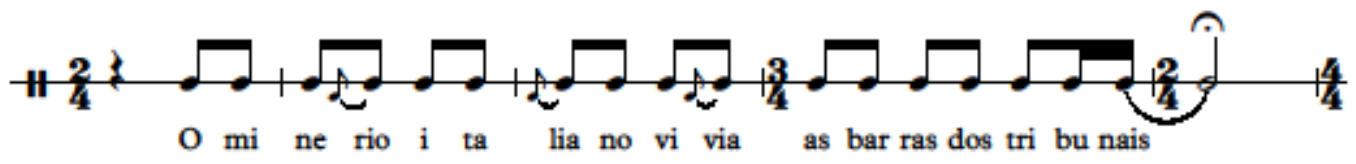

6
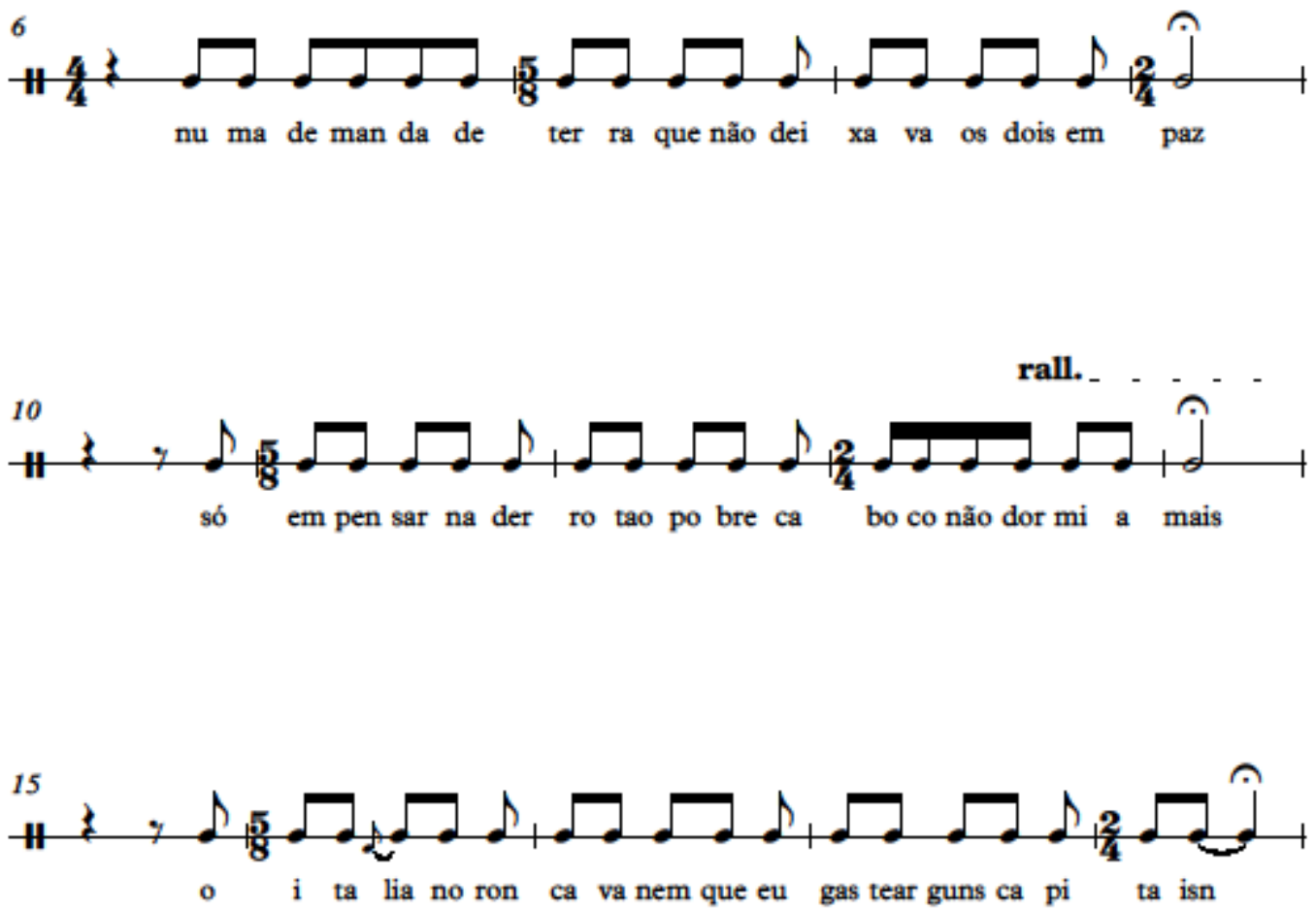

- i ta lia no ron ca va nem que eu gas tear guns ca pi ta isn

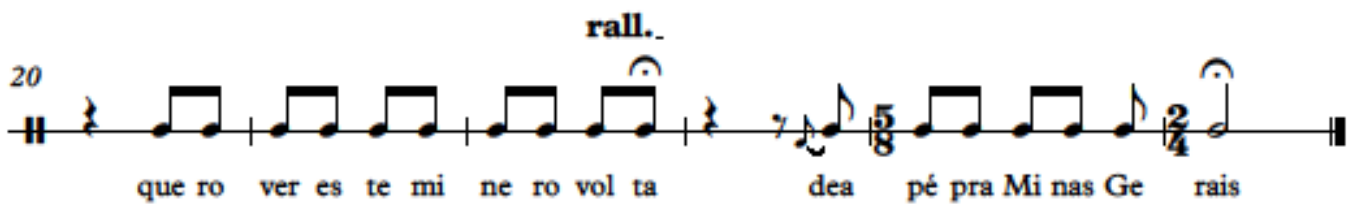




\section{Referências Bibliográficas}

ALONSO, Gustavo. Cowboys do asfalto: música sertaneja e modernização brasileira. 2011. Tese (Doutorado em história) - Universidade Federal Fluminense, Niterói.

AMARAL, Amadeu. O Dialeto Caipira. Casa Editora “O Livro”. SP: 1920.

AMARAL, João Paulo. A trajetória do violeiro Tião Carreiro - das primeiras duplas ao sucesso do criador e rei do pagode. Revista da Tulha, Ribeirão Preto, v. 2, n. 1, p. 144-173, jan.-jun. 2016.

ANDRADE, Mário de. Dicionário Musical Brasileiro. Oneyda Alvarenga, et al. (eds.) Belo Horizonte, Brasília, São Paulo: Itatiaia, Min. da Cultura, IEB, EDUSP, 1989.

. Ensaio sobre a música brasileira. SP: Martins Fontes, 1972.

. Pequena História da Música. BH: Itatiaia, 1987.

Proj. História, 2003.

A pronúncia cantada e o problema do nasal através dos discos. SP:

Sejamos todos musicais: as crônicas na $3^{\text {a }}$ fase da Revista do Brasil. OLIVEIRA, Francini Venâncio de (org.). SP: Alameda, 2013.

ARAÚJO, Lucas Antonio de. Tensões e ajustes entre tradição e modernidade nas definições de padrões da música sertaneja entre os anos 50 e 70. Tese de Doutorado UNESP. Franca : [s.n.], 2014.

BAGNO, Marcos. Preconceito Linguístico: o que é, como se faz. São Paulo: Edições Loyola, 1999.

BARREIROS, Daniel de Pinho. A crise de 1929 e duas elites: São Paulo e Rio de Janeiro diante da Grande Depressão. Estudos Ibero-Americanos, Porto Alegre, v. 35, n. 1, p. 128144, jan./jun. 2009.

BECKER, Bertha. Manual do candidato: geografia; apresentação do Embaixador Georges Lamazière. Brasília: FUNAG, 2012. 196 p. Disponível em http://funag.gov.br/loja/download/1014-Manual_do_candidato__ Geografia.pdf.

BESSA, Virgínia de Almeida. A cena musical paulistana: teatro musicado e canção popular na cidade de São Paulo (1914-1934). Tese de Doutorado. São Paulo: Universidade de São Paulo, FFLCH, 2012.

BIGAZZI, Anna Rosa Campagnano. Italianos: história e memória de uma comunidade. SP: companhia Editora Nacional, 2006.

BOLLE, Wille. grandesertao.br: o romance de formação do Brasil. São Paulo: Duas cidades; Ed. 34, 2004.

BRACKETT, David. Interpreting Popular Music. NY: Cambridge University Press, 1995. 
BRITO, Diogo de Souza. A "série vermelha" de Cornélio Pires: "estrambótica aventura" precursora da produção independente?. Anais do XXVI Simpósio Nacional de História - ANPUH. São Paulo, julho 2011.

CALDAS, Waldenyr. Acordes na aurora: música sertaneja e indústria cultural. 2. ed. São Paulo: Companhia Editora Nacional, 1979.

CALSANI,Rodrigo de Andrade. O imigrante italiano nos corredores dos cafezais : cotidiano econômico na Alta Mogiana (1887-1914). Dissertação de Mestrado. UNESP. Franca: [s.n.], 2010.

CAMARGO, Maria Daniela B. de. Terra Paulista (vol. I). São Paulo : CENPEC / Imprensa Oficial do Estado de São Paulo, 2004.

CAMPOS, Zóia Vilar. Italianos em São Paulo: de colonos a empresários do açúcar. 1876 -1941. Texto integrante dos Anais do XVIII Encontro Regional de História - O historiador e seu tempo. ANPUH/SP - UNESP/Assis, 24 a 28 de julho de 2006. Cd-rom.

CANDIDO, Antonio. Os parceiros do Rio Bonito: estudo sobre o caipira paulista e a transformação dos seus meios de vida. 9a Ed. São Paulo: Duas Cidades/Ed. 34, 2001 e 2017.

Sobre Azul, 2016.

Dialética da Malandragem. In: O discurso e a cidade. SP: Ouro O direito à Literatura. In: Vários Escritos. Ouro Sobre Azul. 2004.

O estudo analítico do poema. SP: Associação Editorial Humanitas, 2006.

CASTELLANI, José. São Paulo na década de trinta. SP: Policor, s/d.

CAVENAGHI, Airton José. O território paulista na iconografia oitocentista: mapas, desenhos e fotografias: análise de uma herança cotidiana. Anais do Museu Paulista. São Paulo.N. Sér. v.14. n.1.p. 195-241. jan.- jun. 2006.

CAVICHIA, Alessandro Henrique Dias. O tradicional e o popular nos ponteios de viola a MPB e a busca pelo autêntico sertão na estética da música caipira. V Congresso Internacional de História: Novas Epistemes e Narrativas Contemporâneas. UFG-Regional Jataí, Jataí-GO, 2016.

CHAVES, Edilson Aparecido. A música caipira em aulas de História: questões e possibilidades. Dissertação de Mestrado. Curitiba: Universidade Federal do Paraná, Programa de Pós-Graduação em Educação, 2006.

CINTRA, Rosana Aparecida. Experiências da imigração italiana no interior paulista: imigração, trajetórias e adaptação. Texto integrante dos Anais do XX Encontro Regional de História: História e Liberdade. ANPUH/SP - UNESP-Franca. 06 a 10 de setembro de 2010. Cd-Rom.

CORREAA. Roberto. A arte de pontear a viola. Brasília: Viola Corrêa, 2002. 
CORRÊA, Roberto L..Geografia: conceitos e temas. Rio de Janeiro, Bertrand Brasil, 2003, p. 49-76.

DA MATTA, Roberto. O que faz o brasil, Brasil?. RJ: Rocco, 1986.

DIAS, Saulo Sandro Alves. Desatando os nós do pagode sertanejo: a rumba no violão do maestro Itapuã. XXIV Congresso da Associação Nacional de Pesquisa e Pós-Graduação em Música. São Paulo, 2014.

DÓRIA, Carlos Alberto. A culinária caipira da Paulistania: a história e as receitas de um modo antigo de comer. Carlos Alberto Dória e Marcelo Corrêa Bastos. São Paulo: Três Letras, 2018.

DUARTE, Geni Rosa Duarte. A música caipira e sua incorporação ao universo radiofônico (São Paulo - 1920-1950). In: ALMIDA, P. R. et AL. (Org). Estado, Poder e Práticas Sociais. Cascavel: EDUNIOESTE, 2006, v., p. 105-125.

Alvorada rural na polifonia urbana: a música caipira no rádio paulistano (1920/1950). Texto integrante dos Anais do XVII Encontro Regional de História - O lugar da História. ANPUH/SPUNICAMP. Campinas, 6 a 10 de setembro de 2004. Cd-rom.

FAORO, Raymundo. Os donos do poder: formação do patronato político brasileiro. SP: Globo, 2012.

FAUSTINO, Jean Carlo. O êxodo cantado: a formação do caipira para a modernidade. Tese de Doutorado. São Carlos: UFSCar, 2014.

- A busca pelos aspectos universais da moda-de-viola. REV. TULHA, RIBEIRÃO PRETO, v. 2, n. 2, p. 154-176, jul.-dez. 2016 (disponível em https://www.revistas.usp.br/revistadatulha/article/view/121319.

A modernidade sincopada: moda de viola e o êxodo rural no Brasil. BRASILIANA - Journal for Brazilian Studies. Vol. 4, n.1 (Aug. 2015). ISSN 22454373.

O êxodo revisitado: a história do processo de adaptação cultural à modernidade em São Paulo segundo a música caipira. X Encontro Nacional de História Oral. Recife, 2010. ISBN 978-85-7315-769-7.

O caipira, o boi e a viola: representação e superação simbólica do caipira diante do êxodo rural em São Paulo.CADERNOS CERU, série 2, v. 20, n. 2, dezembro de 2009.

A história vista debaixo da viola de Tião Carreiro. IV Encontro

de

História da Arte. Campinas: IFCH-UNICAMP, 2008.

para uma

O êxodo cantado: A música tradicional paulista como fonte 
história oral. Oralidades: Revista de História Oral / Núcleo de Estudos em História Oral [do Departamento de História da Faculdade de Filosofia, Letras e Ciências Humanas da Universidade de São Paulo]. -- Ano 1, n. 1 (jan./jun. 2007). São Paulo: NEHO, 2007.

. Entre a formação e a desilusão - literatura e sociedade na moda de viola. Revista Ecos vol.15, Ano X, $\mathrm{n}^{\circ}$ 02, 2013.

O romance de formação (Bildungsroman) na moda de viola literatura e sociedade na música caipira. Revista Ecos vol. n 12 - Ano IX, 2012.

- O êxodo da viola - compreensão do êxodo rural a partir da música caipira. Texto integrante dos Anais do XIX Encontro Regional de História: Poder, Violência e Exclusão. ANPUH/SP - USP. São Paulo, 08 a 12 de setembro de 2008. Cd-Rom.

. Os desafios da viola: o processo civilizador paulista segundo a música caipira. XII Simpósio Internacional Processo Civilizador. Recife; 2009.

A moda de viola e a epopeia caipira: a música enquanto literatura dos povos iletrados. XII Congresso Internacional da ABRALIC: Centro, Centros - Ética, Estética. UFPR, Curitiba, 2011.

FERREIRA, Antonio Celso. A epopéia bandeirante. Letrados, instituições, invenção histórica (1870-1940). São Paulo: Editora UNESP, 2002.

FERRETE, J. L.. Capitão Furtado: viola caipira ou sertaneja?. Rio de Janeiro: Divisão de Música Popular de Instituto Nacional de Música/ Funarte (Coleção MPB, n. 18), 1985.

FONTANARI, Rodrigo. Entrantes mineiros e a cafeicultura paulista: a trajetória da família Villas Boas (1850-1914). XVIII Encontro Regional ANPUH-MG. Mariana, 2012.

FURTADO, Celso. Formação Econômica do Brasil. SP: Companhia das Letras, 2007.

FURTADO, Milton Braga. Síntese da Economia brasileira. RJ: LTC, 2000.

FONTES, Martins. Paulistânia. São Paulo: Martins Fontes, 1984 (1a. edição 1934).

FRAGOSO, João, FLORENTINO, Manolo e FARIA, Sheila de Castro. A economia colonial brasileira (séculos XVI-XIX). SP: Atual, 1998.

FRANCISCO, Luis Roberto de. Terra Paulista (vol. II). São Paulo : CENPEC / Imprensa Oficial do Estado de São Paulo, 2004.

FRANCO, Maria Sylvia de Carvalho. Homens livres na ordem escravocrata. São Paulo: Fundação Editora da UNESP, 1997.

FREIRE, Vanda Bellard. Pesquisa em música e interdisciplinaridade. Música Hodie, Vol. $10-\mathrm{N}^{\mathrm{o}} 1,2010$.

FREITAS, Sérgio Paulo Ribeiro de. Teoria da Harmonia na Música Popular: uma definição das relações de combinação entre os acordes na harmonia tonal. Dissertação 
apresentada ao Programa de Pós-Graduação em Artes da Universidade Estadual Paulista (Mestrado em Artes). SP, 1995.

GARCIA, Rafael Marin da Silva. Moda-de-viola: lirismo, circunstância e musicalidade no canto recitativo caipira. Dissertação de Mestrado. UNESP, São Paulo: [s.n.], 2011.

A viola caipira na Festa de Santo Reis em uma cidade do sul de Minas Gerais. REV. TULHA, RIBEIRÃO PRETO, v. 2, n. 1, p. 92-99, jan.-jun. 2016.

. A volta que o mundo dá. Trabalho de Conclusão de Curso, Universidade de São Paulo Departamento de Música da Escola de Comunicações e Artes. Ribeirão Preto, SP, 2007.

GARCIA, Rosicleide Rodrigues. A entoação do dialeto caipira do Médio Tietê: reconhecimento, características e formação. Tese de Doutorado. FFLCH-USP, São Paulo, 2015.

GARCIA, Walter. Melancolias, Mercadorias: Dorival Caymmi, Chico Buarque, o Pregão de Rua e a Canção Popular-Comercial no Brasil. SP: Ateliê Editorial, 2013.

GHIRARDELlO, Nilson. A ocupação da terra rural na zona Noroeste Paulista. In: À beira da linha: formações urbanas da Noroeste Paulista [online]. São Paulo: Editora UNESP, 2002. 235 p. ISBN 85-7139-392-3. Available from SciELO Books $<$ http://books.scielo.org $>$.

GOES FILHO, Synesio Sampaio. Navegantes, bandeirantes, diplomatas: um ensaio sobre a formação das fronteiras do Brasil. Brasília: FUNAG, 2015.

GOMES, Natanael dos Santos e SOLLES, Ramon Amancio. As transformações sociais e culturais presentes nas músicas de Tião Carreiro e Pardinho. RJ: Revista Phil ologus, Ano 21, N 61, Supl.: Anais do VII SINEFIL, 2015.

GOMES, Paulo C. da C.. O conceito de região e sua discussão. In: CASTRO, Iná E., s/d.

GONÇALVES, Camila Koshiba. Música em 78 rotações - "Discos a todos os preços" na São Paulo dos anos 30. São Paulo: Alameda, 2013.

GONZÁLEZ, Juliana Pérez. Da música folclórica à música mecânica: uma história do conceito de "música popular" por intermédio de Mário de Andrade. Dissertação de Mestrado. FFLCH-USP, São Paulo, 2012.

A indústria fonográfica e a música caipira gravada: uma experiência paulista (1878-1930). Tese de Doutorado. FFLCH-USP, São Paulo, 2018.

El mito del origen indígena-jesuítico del cateretê en la historiografía brasileña. Resonancias vol. 20, n 38, enero-junio 2016, pp. 37-54.

. “Ô de casa!": gramofones na roça e caipiras na fonografia (1929). ArtCultura, Uberlândia, v. 19, n. 34, p. 39-56, jan.-jun. 2017. 
GREGOLIM Jr., Luiz Manoel. Presença do Sagrado na música caipira de raiz brasileira: análise de composições de Tião Carreiro e Pardinho. Dissertação de Mestrado. São Paulo: Universidade Presbiteriana Mackzenzie, 2011.

HOLANDA, Sérgio Buarque de. Raízes do Brasil. SP: Companhia das Letras, 1995.

em 10 Vol.. SP/RJ: Difel, 1977. (dir.). História Geral da Civilização Brasileira. Coleção

Companhia das Letras, 2015.

Monções e Capítulos de Expansão Paulista (caixa). SP:

IKEDA, Alberto T.. Música na terra paulista: da viola caipira à guitarra elétrica in: Coleção Terra Paulista: histórias, arte, costumes. Manifestações artísticas e celebrações populares no Estado de São Paulo (VOLUME 3). coord. Maria Alice Setubal, SP: Imprensa Oficial do Estado, 2004.

Culturas populares no presente: fomento, salvaguarda e devoração. Estudos Avançados 27 (79), 2013.

KOWARICK, Lúcio. Trabalho e vadiagem - A origem do trabalho livre no Brasil. São Paulo: Editora 34, 2019.

LEITE, Sylvia Helena Telarolli de Almeida. Chapéus de palha, panamás, plumas, cartolas: a caricatura na literatura paulista (1900-1920). São Paulo: Unesp, 1996.

LÉVY, Jacques. Qual o sentido da Geografia Cultural?. Tradução: Jaime Oliva. Revista do Instituto de Estudos Brasileiros, Brasil, n. 61, p. 19-38, ago. 2015. doi: http://dx.doi.org/10.11606/issn.2316-901X.v0i61p19-38.

LOPES, Adriana e MOTA, Carlos Guilherme. História do Brasil: uma interpretação. SP: Editora SENAC, 2008.

LOPES, José Rogério e SILVA, André Luiz da. Os lugares da viola no Vale do Paraíba (SP). Sociedade e Cultura, v.11, n.2, jul/dez. 2008. p. 183 a 190.

MACHADO, Alcântara. Vida e Morte do Bandeirante. Brasília: Editora UnB/Fundação Darcy Ribeiro, 2014.

MALAQUIAS, Rilk. O pagode de viola de Tião Carreiro: configurações estilísticas, importância e influências no universo da música violeirística brasileira. Dissertação (Mestrado) - Universidade Federal de Goiás, Escola de Música e Artes Cênicas, 2013.

MANOEL, Diogo Silva. Comicidade e identidade na obra musical de Tião Carreiro: pagode de viola, cultura e identidade caipira no século $\mathbf{X X}$. Dissertação de Mestrado. Assis, 2016.

MANUEL, Peter. From Scarlatti to "Guantanamera": Dual Tonicity in Spanish and Latin American. Journal of the American Musicological Society, Vol. 55, No. 2 (Summer 2002), pp. 311-336. URL: http://www.jstor.org/stable/10.1525/jams.2002.55.2.311 . 
MARIANO, Neusa de Fátima. Herdeiros da rusticidade: a cultura caipira no município de Jaú (SP). GEOUSP - Espaço e Tempo, São Paulo, No 17, pp. 43 - 59, 2005.

MARTINS, José de Souza. Música Sertaneja: a dissimulação na linguagem dos humilhados: Capitalismo e tradicionalismo. São Paulo: Livraria Pioneira, 1975.

A sociabilidade do homem simples: cotidiano e história na modernidade anômala. $3^{\mathrm{a}}$ Ed., $4^{\mathrm{a}}$ reimpressão. São Paulo: Contexto, 2017.

MAZOTI, Lays. "Sem ordi não há porgueço e nois semo desordeiro!": humor, paródia e vida urbana em Alvarenga e Ranchinho. Marechal Cândido Rondon, 2011.

MEDICCI, Ana Paula. Para além de escravos e senhores: sociedade e economia paulistas entre 1750 e 1850. Revista de Estudos Avançados, 20 (57), 2006.

MELO Jr., João Alfredo Costa de Campos. O Conceito de Experiência Histórica em Edward Thompson. Anais do XXVI Simpósio Nacional de História - ANPUH • São Paulo, julho, 2011. Disponível em: $<$ www.snh2011.anpuh.org/resources/anais/14/1300653140_ARQUIVO_Anpuh2011.pdf $>$ Acesso em 20/10/16.

MELON, Cláudio Armelin. Transformação da música sertaneja do século XX: o jogo da contenção e absorção. XXVII Simpósio nacional - ANPUH: Conhecimento histórico e diálogo social. Natal, 2013.

MENESES, Ulpiano T. Bezerra de. A História, cativa da memória? Para um mapeamento da memória no campo das Ciências Sociais. Rev. Inst. Est. Bras., SP: 1992, p. 9-24.

MORAES, José Geraldo Vinci de. Cantar e contar o cotidiano: as modinhas paulistanas (anos 20/30). Cláudia Neiva de Matos, et al. (ed.) Palavra Cantada. Ensaios sobre poesía, música e voz. Rio de Janeiro: Faperj; 7 Letras, 2008. pp. 181-191.

MORAES, José Geraldo Vinci de Morais, SALIBA, Elias Thomé (orgs.). História e Música no Brasil. SP: Alameda, 2010.

NEGRÃO, Georgia Caprioli. O falar rural presente na música de raiz. Anais do $6^{\circ}$ Encontro Celsul - Círculo de Estudos Linguísticos do Sul. Universidade Estadual de Londrina, Londrina, s/d..

NEPOMUCENO, Rosa. Música caipira: da roça ao rodeio. São Paulo: Editora 34, 1999.

NICOLAZZI, Fernando. $O$ conceito de experiência histórica e a narrativa historiográfica. Dissertação de Mestrado. Universidade Ferderal do Rio Grande do Sul. Porto Alegre, 2004.

OLIVEIRA, Allan de Paula. Miguilim foi pra cidade ser cantor: uma antropologia da música sertaneja. Tese de Doutorado. Florianópolis: Universidade Federal de Santa Catarina, Antropologia Social. Centro de Filosofia e Ciências Humanas, 2009.

OLIVEIRA, Lúcia Lippi. A conquista do espaço: sertão e fronteira no pensamento brasileiro. História, Ciências, Saúde - Manguinhos, Rio de Janeiro, Vol. V (suplemento), pp. 195-215, Julho 1998. 
PAZETTI, H. A. O lugar da música caipira. In: VI Semana de Geografia da Unicamp, 1., 2010, Campinas. Anais... Campinas: [online: http://www.ige.unicamp.br/cact/semana2010].

PETRONE, Maria Tereza Schorer. Imigração. In: História geral da Civilização Brasileira Tomo III - O Brasil Republicano - $2^{\circ}$ volume - Sociedade e Instituições (1889-1930) Sergio Buarque de Holanda (org.). RJ: Difel, 1978.

PICINATO, Pricila Balan. O novo "caipira": o olhar do "eu" e do "outro". Dissertação de Mestrado. UNESP, Araraquara, 2013.

PINTO, João Paulo do Amaral. A Viola Caipira de Tião Carreiro. Dissertação de Mestrado. UNICAMP. Campinas, SP: [s.n.], 2008.

A trajetória do violeiro Tião Carreiro: das primeiras duplas ao sucesso do criador e rei do pagode. REV. TULHA, RIBEIRÃO PRETO, v. 2, n. 1, p. 144-173, jan.-jun. 2016.

PRADO Jr., Caio. Formação do Brasil Contemporâneo: colônia. SP: Companhia das Letras, 2011.

RIBEIRO, Darcy. O povo brasileiro: a formação e o sentido do Brasil. São Paulo: Companhia das Letras, 1995, 2006 e 2015.

SALIBA, Elias Thomé. Raízes do riso: a representação humorística na história brasileira da Belle Époque aos primeiros tempos do rádio. São Paulo: São Paulo Companhia das Letras, 2002.

SALVADOR, Frei Vicente do. Historia do Brasil 1500-1627. Livro Digital (PDF). Fundação Darcy Ribeiro. Disponível em http://www.fundar.org.br/bbb/index.php/project/historia-do-brasil-1500-1627-frei-vicente-dosalvador/.

SAMPAIO, Antonio Carlos Jucá de. In: FRAGOSO, João Luiz Ribeiro e GOUVÊA, Maria de Fátima (orgs.). O Brasil Colonial, Vol. 3. RJ: Civilização Brasileira, 2014.

SANT'ANNA, Romildo. A moda é viola: ensaio do cantar caipira. Unimar/Arte e Ciência, 2009.

SANTANA, Antônio de Jesus. Concepções de felicidade e tragédia na música raiz sertaneja como elementos de educação entre sujeitos. Dissertação de Mestrado. Americana: Centro Universitário Salesiano de São Paulo, 2015.

SANTOS, Jonas Rafael dos. Imigração e Ascenção Social em Ribeirão Preto entre o final do século XIX e meados do XX. Dispponível em: https://docplayer.com.br/9912466Imigracao-e-ascencao-social-em-ribeirao-preto-entre-o-final-do-seculo-xix-e-meados-do-XXjonas-rafael-dos-santos-1.html

SCATIMBURGO, João. Os paulistas. SP: Imprensa Oficial do Estado de São Paulo, 2006.

SETUBAL, Maria Alice. Vivências caipiras: pluralidade cultural e diferentes 
temporalidades na terra paulista. São Paulo : CENPEC / Imprensa Oficial do Estado de São Paulo, 2005.

(org.). Terra Paulista (coleção em 3 vol.). São Paulo : CENPEC / Imprensa Oficial do Estado de São Paulo, 2004.

SEVERIANO, Jairo. Uma história da música popular brasileira: das origens à modernidade. São Paulo: Editora 34, 2008.

SILVA, Albert Stuart Rafael Pinto da. Representações de Caipira nas Práticas Literárias de Cornélio Pires. Dissertação de Mestrado. Programa de Pós-Graduação em Educação Universidade Metodista de Piracicaba, 2008.

SILVA, Antônio Sá da. O continuum de justiça e vingança na literatura oral do sertão: uma releitura da tragédia e do tratamento da controvérsia no cordel e na música caipira. R. Fac. Dir. UFG, v. 42, n. 2, p.198-221, maio/ago., 2018.

SILVA, Dionísio da. De onde vêm as palavras - origens e curiosidades da língua portuguesa. SP: Girafa, 2004.

SIQUEIRA, Uassyr de. Folclore, música caipira e trabalho (Piracicaba, 1940-1950). Tempos Gerais - Revista de Ciências Sociais e História - UFSJ Número \#2 - 2015 - ISSN: $1516-8727$.

SOUSA, Rainer Gonçalves. As diferentes noções de mudança dentro da música caipira: uma reflexão sobre a obra de Tião Carreiro. Fronteiras, Dourados, MS, v. 10, n. 17, jan./jun. 2008.

TAGG, Philip. Analisando a música popular: teoria, método e prática. Em Pauta - v. 14, $\mathrm{n}^{\circ} 23$, dezembro de 2003.

. Análise musical para "não-musos": a percepção popular como base para

a compreensão de estruturas e significados musicais. Tradução de Fausto Borém (UFMG, Belo Horizonte, MG). Per Musi, Belo Horizonte, n.23, 2011, p.7-18.

TATIT, Luiz. O Século da Canção. Cotia: Ateliê Editorial, 2004.

TAUNAY, Afonso d'Escragnolle. História das Bandeiras Paulistas: Leituras Básicas (seleção e introdução de Antonio Paim). Centro de Documentação do Pensamento Brasileiro, 2012.

TINHORÃO, José Ramos. Pequena História da Música Popular - segundo seus gêneros. SP: Editora 34, 2013.

TRAVASSOS, Elizabeth. Tradição Oral e História. Revista de História 157 ( $2^{\circ}$ semestre de 2007), 129-152.

ULHÔA, Martha Tupinambá de. Métrica Derramada: tempo rubato ou gestualidade na canção brasileira popular. RJ: UNIRIO-CNPq, s/d. 
ArtCultura v. 9, 2004, pp. 56-65.

Música Sertaneja em Uberlândia na década de 1990.

. Música Sertaneja e Globalização. In: Rodrigo Torres (Ed) Música Popular en América Latina. Santiago, Chile: Fondart. Rama Latinoamericana IASPM, 1999, p. $47-60$.

VELLOSO, Mônica Pimenta. A brasilidade verde-amarela: nacionalismo e regionalismo paulista. Estudos Históricos, Rio de Janeiro, vol. 6, n. 11, 1993, p. 89-112.

VICENTE, Eduardo. Chantecler: uma nova gravadora popular paulista. Revista USP, São Paulo, n. $87, \quad$ p. $74-85$, set./nov. 2010. Disponível em http://producao.usp.br/handle/BDPI/32363 (acesso: julho/2019), p. 79).

A gravadora Chantecler e a música regional do Brasil. ESTUDOS AVANÇADOS 31 (90), 2017.

Da vitrola ao iPod - uma história da industria fonográfica no

Brasil. São Paulo : Alameda, 2014.

VIEIRA, Noemia Ramos. O conceito de região e o ensino de Geografia: desencontros entre o saber escolar e o saber acadêmico. Revista Formação, n.20, volume 1, Ano 2013 p. 21-37.

VILLAÇA, Paulo Ignácio Corrêa. Terra e Poder no Sertão Paulista: Dominação de Classe e Conflito de Terras no Pontal do Paranapanema (Autos da Comarca de Presidente Prudente - 1890/1940). XIV Encontro Regional da ANPUH-RIO: Memória e Patrimônio, RJ, 2010.

VIOLA, Braz da. Manual do Violeiro. SP: Ricordi, 1999.

VILELA, Ivan. Cantando a própria história: Música Caipira e Enraizamento. São Paulo: Edusp, 2015.

Vem viola, vem cantando. Estudos Avançados, v.24, n.69, p.323-347,

2010.

WOORTMANN, Klass. "Com Parente Não se Neguceia": o campesinato como ordem moral. Anuário Antropológico/87: Editora Universidade de Brasília/Tempo Brasileiro, 1990.

XIDIEH, Osvaldo Elias. Narrativas Pias Populares. São Paulo: Instituto de Estudos Brasileiros, 1967.

ZAN, José Roberto. Tradição e assimilação na música sertaneja. Disponível em http://www.brasa.org/wordpress/Documents/BRASA_IX/Jose-Roberto-Zan.pdf, 2004.

\section{Fontes da Internet:}

$\underline{\text { http://enciclopedia.itaucultural.org.br/pessoa531172/tiao-carreiro }}$ 
http://dicionariompb.com.br/teddy-vieira/dados-artisticos 